\title{
Corrosion Mechanisms of High-Mn Twinning-Induced Plasticity (TWIP) Steels: A Critical Review
}

\author{
David M. Bastidas*(D), Jacob Ress (D), Juan Bosch (D) and Ulises Martin \\ National Center for Education and Research on Corrosion and Materials Performance, NCERCAMP-UA, \\ Department Chemical, Biomolecular, and Corrosion Engineering, The University of Akron, 302 E Buchtel Ave, \\ Akron, OH 44325-3906, USA; jtr45@zips.uakron.edu (J.R.); jb394@zips.uakron.edu (J.B.); \\ um11@zips.uakron.edu (U.M.) \\ * Correspondence: dbastidas@uakron.edu
}

Citation: Bastidas, D.M.; Ress, J.; Bosch, J.; Martin, U. Corrosion Mechanisms of High-Mn Twinning-Induced Plasticity (TWIP) Steels: A Critical Review. Metals 2021, 11, 287. https://doi.org/10.3390/ met11020287

Academic Editor: Marcello Cabibbo Received: 31 December 2020

Accepted: 4 February 2021

Published: 7 February 2021

Publisher's Note: MDPI stays neutral with regard to jurisdictional claims in published maps and institutional affiliations.

Copyright: (c) 2021 by the authors. Licensee MDPI, Basel, Switzerland. This article is an open access article distributed under the terms and conditions of the Creative Commons Attribution (CC BY) license (https:// creativecommons.org/licenses/by/ $4.0 /)$.
Abstract: Twinning-induced plasticity (TWIP) steels have higher strength and ductility than conventional steels. Deformation mechanisms producing twins that prevent gliding and stacking of dislocations cause a higher ductility than that of steel grades with the same strength. TWIP steels are considered to be within the new generation of advanced high-strength steels (AHSS). However, some aspects, such as the corrosion resistance and performance in service of TWIP steel materials, need more research. Application of TWIP steels in the automotive industry requires a proper investigation of corrosion behavior and corrosion mechanisms, which would indicate the optimum degree of protection and the possible decrease in costs. In general, Fe-Mn-based TWIP steel alloys can passivate in oxidizing acid, neutral, and basic solutions, however they cannot passivate in reducing acid or active chloride solutions. TWIP steels have become as a potential material of interest for automotive applications due to their effectiveness, impact resistance, and negligible harm to the environment. The mechanical and corrosion performance of TWIP steels is subjected to the manufacturing and processing steps, like forging and casting, elemental composition, and thermo-mechanical treatment. Corrosion of TWIP steels caused by both intrinsic and extrinsic factors has posed a serious problem for their use. Passivity breakdown caused by pitting, and galvanic corrosion due to phase segregation are widely described and their critical mechanisms examined. Numerous studies have been performed to study corrosion behavior and passivation of TWIP steel. Despite the large number of articles on corrosion, few comprehensive reports have been published on this topic. The current trend for development of corrosion resistance TWIP steel is thoroughly studied and represented, showing the key mechanisms and factors influencing corrosion processes, and its consequences on TWIP steel. In addition, suggestions for future works and gaps in the literature are considered.

Keywords: high-Mn TWIP steel; passivity; pitting corrosion; stress corrosion cracking; hydrogen embrittlement; high temperature corrosion; welding

\section{Introduction}

Steel used in the automotive industry can be classified into three categories determined by their tensile strength: Mild steels have a tensile strength less than $300 \mathrm{MPa}$, high strength steels (HSS) show a tensile strength between $300 \mathrm{MPa}$ and $700 \mathrm{MPa}$, and ultra-high strength steels (UHSS) boast a tensile strength above $700 \mathrm{MPa}$ [1]. Recently, advances in HSS led to the development of advanced high-strength steels (AHSS) designed for lighter weight and cost effectiveness. The evolution has been constant, and nowadays it is possible to speak of a third generation of AHSS. The major difference between conventional HSS and AHSS is the microstructure. HSS exhibit a single ferrite phase, whereas AHSS presents ferrite, martensite, bainite, and/or retained austenite in sufficient amounts to affect mechanical properties. Some AHSS have increased hardenability and greater strengthductility compared to conventional steels. The manufacturing of AHSS is more complex than conventional steel and require greater manufacturing control due to the required 
percentages of different phases. Within the group of AHSS, there are several groups: Dual-phase (DP), transformation-induced plasticity (TRIP), complex phase (CP), highstrength low alloy (HSLA) steel, ferritic-bainitic (FB), twinning-induced plasticity (TWIP), and hot formed (HF) post-forming heat-treatable (PFHT) [1].

TWIP steel is defined by a single austenite phase, which is stable at room temperature and can be deformed by dislocation gliding in specific slip planes induced by mechanical or deformation twinning [2-11]. Furthermore, high-Mn TWIP steel is a high-strength, structural steel with superior formability. TWIP steel offers enhanced mechanical properties by strain hardening modification. Therefore, the use of TWIP steel may decrease the weight of steel components and improve press forming behavior. These key advantages coincide with current trends in the automotive industry, which emphasize reduced greenhouse gas emissions and lower fuel consumption [12-14]. The high-Mn TWIP steels have greater strength and ductility compared to all other classes of steels for automotive application, as shown in Figure 1a,b [15]. The high strain hardening leads to enhanced press forming performance, as illustrated in Figure 2 [14,16-22].

(a)

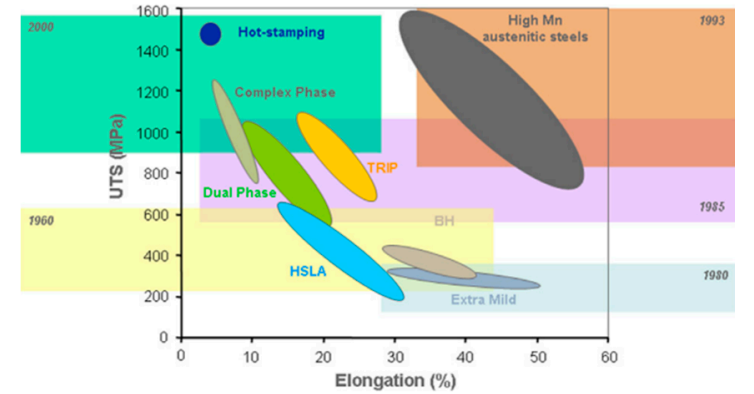

(b)

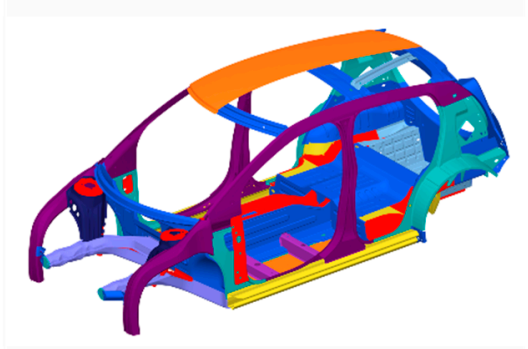

(c) FSV BEV Steel Types

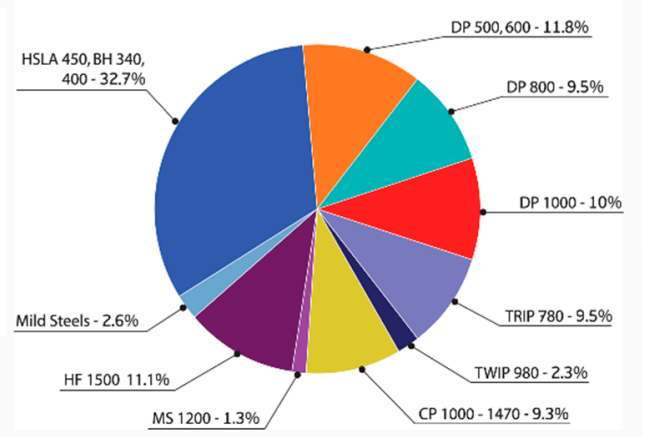

Figure 1. Advanced high strength steels (for example, dual-phase (DP), complex phase (CP), transformation-induced plasticity (TRIP), twinning-induced plasticity (TWIP)) in automotive industry, (a) mechanical properties, (b,c) different applications on the car body or on the chassis [23,24]. (Reproduced with permission from refs. [23,24]. Copyright $(2011,2017)$, Elsevier). 


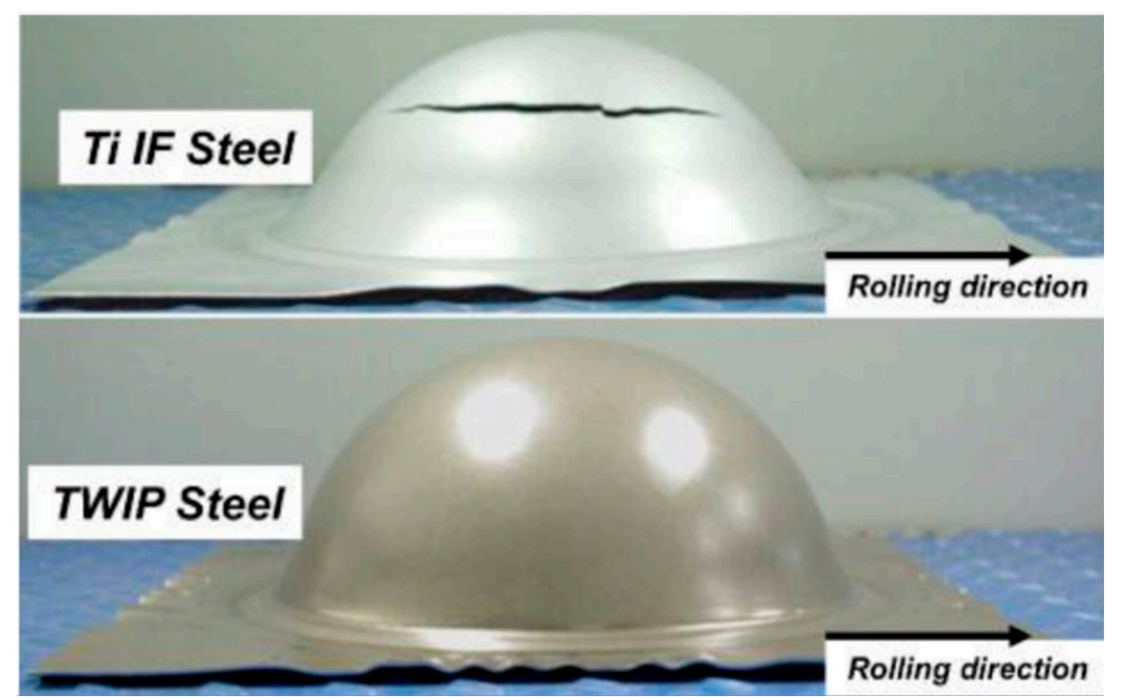

Figure 2. Comparison of Nakashima test samples for interstitial-free (IF) and TWIP steels [14]. (Reproduced with permission from refs. [14]. Copyright (2012), Taylor \& Francis).

TWIP steel shows dislocation glide as the major deformation mechanism, however due to the Hall-Petch effect, mechanical twins are continuously forming during strain. The mechanical twins involve new crystal orientations, thus reducing the 'mean free path' or effective glide distance of dislocations and increase the flow stress. The increase in twin density causes in high strain hardening observed in TWIP steel. Precisely, controlling stacking fault energy (SFE) governs twin formation; values below $20 \mathrm{~mJ} \mathrm{~m}^{-2}$ are more likely to induce strain transformation, whereas SFE values greater than $50 \mathrm{~mJ} \mathrm{~m}^{-2}$ suppresses twin formation [14]. The mechanism for strain hardening in TWIP steel is described as the Hall-Petch effect, illustrated in Figure 3.
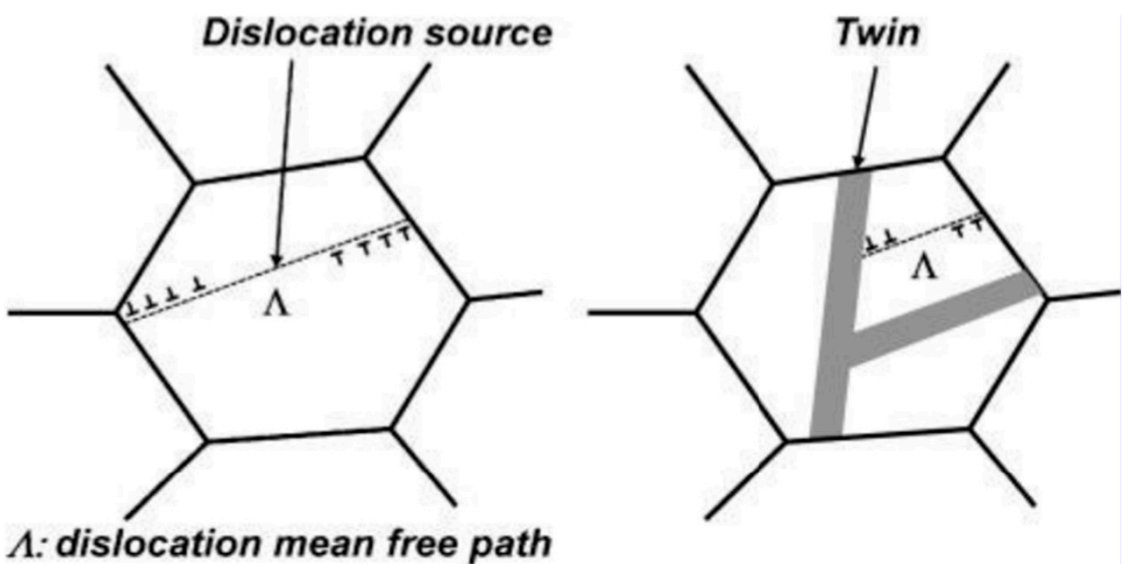

Figure 3. Schematic of strain hardening mechanism in TWIP steels [14]. (Reproduced with permission from refs. [14]. Copyright (2012), Taylor \& Francis).

The formation of mechanical twins has been studied in the literature using the method of observing textures in the microstructure. Transmission electron microscopy (TEM) and electron backscattered diffraction (EBSD) indicated an increase in the volume fraction of twinning with plastic deformation [25-29]. During cold rolling of the high-Mn TWIP steel, the development of pronounced brass-type evolution at low strain levels is produced due to the high Mn content [30].

High-Mn steel have grown in popularity owing to their relationship between cost, strength, ductility, and density [31]. The effect of work hardening on TWIP steels shows a greater benefit than any other austenitic steels. The deformation twins, it is believed, 
act as pinning centers for gliding dislocation, thus increasing the work-hardening rate. Moreover, TWIP steels simultaneously display high strength and high ductility, it is found that nanometer scale twinning (nano-twinning) is significant for improvement of ductility according to recent works regarding metals and alloys [23]. The two prominent plastic deformation mechanisms are dislocation slip and deformation twinning. The superior dislocation storage capacity favors deformation twinning and benefits work hardening and ductility improvement [32-37].

The main alloying element in TWIP steels, Mn, is a key factor in preserving the austenitic structure and maintaining a low SFE value to allow for mechanical twinning, yet high enough to avoid martensitic transformation [31,38,39]. Both $\mathrm{Mn}$ and $\mathrm{Ni}$ are gammagenous elements that favor the formation of austenite phase.

$\mathrm{Al}$ is a ferrite stabilizer and does not stabilize the austenite, however it increases the SFE and accordingly favors the formation of twins (TWIP effect) over martensitic transformation (TRIP effect) during deformation [28,40-43]. Additionally, Al offers increased strength imparted through solid-solution hardening. Moreover, Al improves the corrosion resistance of TWIP steels by formation of a thin, stable surface oxide layer [44]. The addition of $\mathrm{Al}$ has been shown to be successful in the delay of fracture in press-formed parts [45]. Nevertheless, $\mathrm{Al}$ additions cause a lower strain hardening rate, consequently exhibiting a decreased tensile strength [46].

Contrary to $\mathrm{Al}, \mathrm{Si}$ additions decrease the austenite phase formation and aids the transformation of $\gamma$-austenite to $\varepsilon$-martensite throughout the cooling and deformation process [47]. Silicon provides benefits for passivating intermetallic materials, such as $\mathrm{Fe}_{3} \mathrm{Al}-\mathrm{Si}$ and $\mathrm{Fe}_{3} \mathrm{Al}-\mathrm{Ge}$, and additions increase the breakdown pitting potential $\left(E_{\text {pit }}\right)$ and the extent of passivation [48].

Additions of $\mathrm{Cr}$ to ferrous alloys stimulates the passive layer formation, therefore improving corrosion resistance [49]. A ferrite stabilizing agent, $\mathrm{Cr}$ increases $\mathrm{N}$ stability in the melt during the casting process [50]. Yet, adding $\mathrm{Cr}$ to the $\mathrm{Fe}-\mathrm{Mn}$-based alloy causes an increase in the SFE [51].

Carbon can be used as an alloying element to stabilize austenite and strengthen the matrix due to solid solution hardening $[2,28]$. For instance, in order to produce stable austenite in alloys with Mn less than $25 \mathrm{wt} . \%$ and at room temperature, $\alpha^{\prime}$ - and $\varepsilon$-martensite formation must be suppressed. The addition of $C(\sim 0.6 \mathrm{wt} . \%)$ allows the formation of carbide-free austenitic structures while avoiding the formation of $\varepsilon$-martensite. However, higher amounts of $C$ results in carbide $\left(\mathrm{M}_{3} \mathrm{C}\right)$ formation. Carbon and $\mathrm{N}$ are used to produce stable austenite structure and $\mathrm{N}$ also improves the pitting corrosion resistance [50].

The constituent phase found in cast $\mathrm{Fe}-\mathrm{Mn}$ binary alloys can be seen in Figure 4 [52]. As released recently by the authors, the stability of the austenite phase in high-Mn steels is increased, showing a single $\gamma$-austenite phase in the temperature range of $800-1200{ }^{\circ} \mathrm{C}$ [53].

The excellent tensile strength and ductility, along with the significant energy absorption capacity during high impact events highlight the potential for high-Mn TWIP steel $(15-30 \mathrm{wt} . \% \mathrm{Mn})$ in the automotive industry. These characteristics provide increased safety to automobile passengers, greater than twice that of conventional HSS, i.e., TRIP steel and DP steel, such as TRIP700 and DP600, respectively [54-56].

The development of highly deformable TWIP steels in the automotive industry has been actively pursued for weight reduction, thus decreasing $\mathrm{CO}_{2}$ emissions, and increasing the fuel efficiency [2,3]. The quaternary system of $\mathrm{Fe}-\mathrm{Mn}-\mathrm{Al}-\mathrm{C}$ steel achieves higher density reduction $\sim 18 \%\left(6.5 \mathrm{~g} \mathrm{~cm}^{-3}\right)$ than conventional steels, increased strength, an ultimate tensile strength (UTS) $\sim 1 \mathrm{GPa}$, and excellent ductility $>80 \%$. 


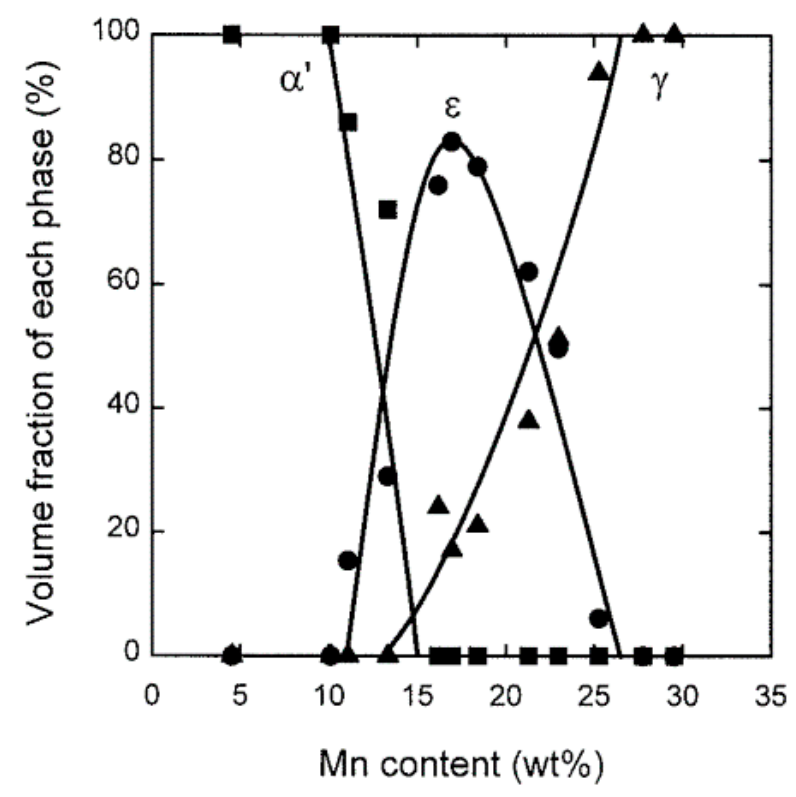

Figure 4. Volume fraction of each constituent phase in cast $\mathrm{Fe}-\mathrm{Mn}$ alloys versus concentration of $\mathrm{Mn}$ in the alloy [52]. (Reproduced with permission from refs. [52]. Copyright (1997), ISIJ international).

The Fe-Mn-C system began with the work of Hadfield in 1988. During deformation, the austenite remains stable and elongation is enhanced by twinning induced plastic deformation [57]. Fe-(11-14)Mn-(1.1-1.4)C, also known as Hadfield steels, contain a high amount of Mn and are described in ASTM standard for their development standards and use in industry [58]. In the 1980s, $\mathrm{Fe}-\mathrm{Mn}-\mathrm{Al}$ alloys were developed to decrease cost and replace 300 series austenitic stainless steels (SS) [59]. The development of TWIP steel is driven by the need for low-cost stainless steel by replacing Ni with $\mathrm{Mn}$ and $\mathrm{Cr}$ with $\mathrm{Al}$ to achieve austenite stability and decrease material cost while simultaneously imparting corrosion protection. The stock prices for $\mathrm{Ni}$ and $\mathrm{Mn}$ are shown in Figure 5, the increasing trend evidences the economic incentive to replace Ni with $\mathrm{Mn}$. Table 1 summarizes current production grades of TWIP steels for automotive applications [24,60].

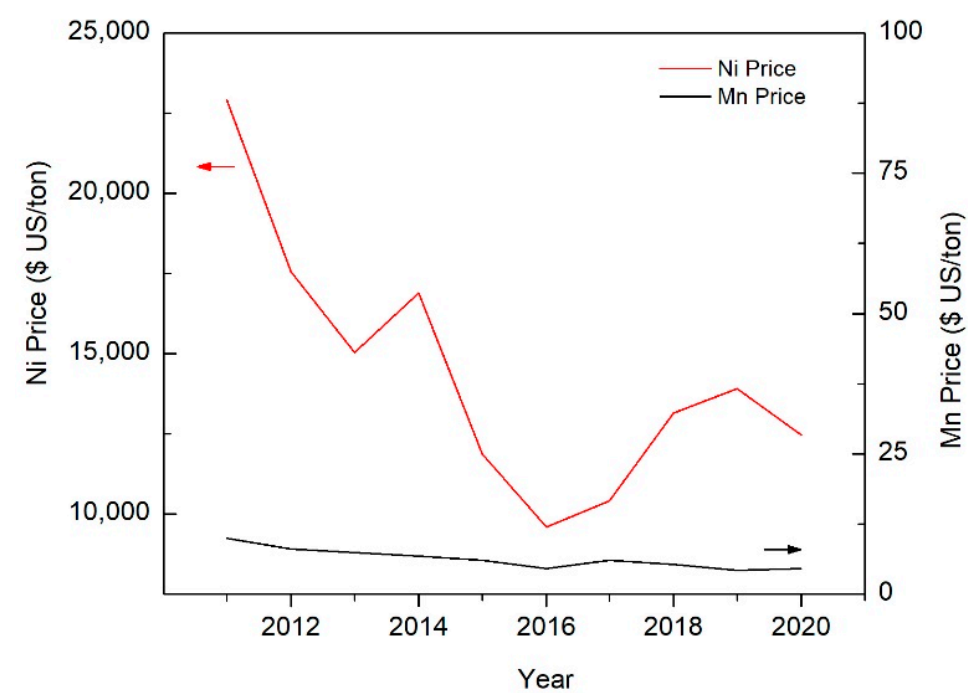

Figure 5. Average price (\$US/ton) for Ni and Mn metals over the last decade (2011-2020). 
Table 1. Current production grades of TWIP steels for automotive applications $[24,60]$.

\begin{tabular}{ccccc}
\hline TWIP Grade & $\begin{array}{c}\text { Yield Strength } \\
\mathbf{( M P a )}\end{array}$ & $\begin{array}{c}\text { Ultimate Tensile } \\
\text { Strength (MPa) }\end{array}$ & $\begin{array}{c}\text { Total Elongation } \\
\mathbf{( \% )}\end{array}$ & Automotive Application \\
\hline TWIP 500/900 & 500 & 900 & 50 & $\begin{array}{c}\text { A-pillar, wheelhouse, front side member } \\
\text { Wheel, lower control arm, front and rear } \\
\text { bumper beams, B-pillar, wheel rim } \\
\text { TWIP 500/980 }\end{array}$ \\
TWIP 600/900 & 600 & 980 & 50 & Floor cross-member, wheelhouse \\
TWIP 750/1000 & 750 & 900 & 45 & Door impact beam \\
TWIP 950/1200 & 950 & 1000 & 35 & Door impact beam \\
\hline
\end{tabular}

The aim of this review is to perform a holistic examination of current literature on high-Mn TWIP steels for identification of a number of critical factors that need to be considered to study the corrosion mechanism of high-Mn TWIP steels, and will affect the electrochemical corrosion behavior, material performance and lifetime in service, such as chemical composition, impurity phase-segregation, grain-size, crystal-phases and environment. For that reason, this work would help in developing a better approach to mitigate corrosion phenomena, making TWIP steels more suitable for even more applications.

\section{Effect of Alloying Elements on Aqueous Corrosion Behavior of High-Mn TWIP Steels}

Current corrosion studies focused on high-Mn TWIP steel focus on the effects of alloying elements added to the base Fe-Mn TWIP alloy, such as Al, Cr, Si, Cu, P, N, and others. Generally, alloying elements provide passive film formation and galvanic-coupling effects of TWIP steel due to the formation of different phases. These mechanisms are discussed in detail in the following sections.

\subsection{Effect of Al Alloying on High-Mn TWIP Steel Corrosion}

Additions of 25 wt.\% Mn to steel in Fe-Mn binary alloys was discovered to be disadvantageous to the corrosion resistance, as the significant amount of Mn causes the alloy to become reactive in acid and chloride environments [61]. Fe-25Mn alloy showed difficulty towards passivation, even in neutral $1 \mathrm{M} \mathrm{Na}_{2} \mathrm{SO}_{4}$ solution. With increasing $\mathrm{Al}$ content to $5 \mathrm{wt} . \%$, the anodic polarization curve of $\mathrm{Fe}-25 \mathrm{Mn}-5 \mathrm{Al}$ alloy showed a stable passivation region in $1 \mathrm{M} \mathrm{Na}_{2} \mathrm{SO}_{4}$ solution; contrarily, no passivation in $3.5 \mathrm{wt} . \% \mathrm{NaCl}$ solution was observed.

The corrosion behavior of $\mathrm{Fe}-25 \mathrm{Mn}-5 \mathrm{Al}-0.15 \mathrm{C}$ alloy and the effects of $\mathrm{Al}$ alloying were studied in $10-15 \% \mathrm{NaOH}, 1 \mathrm{M} \mathrm{Na}_{2} \mathrm{SO}_{4}, 3.5$ wt. $\% \mathrm{NaCl}, 10-15 \% \mathrm{HNO}_{3}$, and $10 \% \mathrm{HCl}$ solutions by Zhang and Zhu [61]. The Al content increase yielded an increase of corrosion potential $\left(E_{\text {corr }}\right)$ and a decrease of corrosion current density $\left(i_{\text {corr }}\right)$, whereas the increase in $\mathrm{Mn}$ reduced the corrosion resistance. The changes in corrosion behavior were ascribed to the standard electrode potential of $\mathrm{Al}(-1.66 \mathrm{~V}$ vs. SHE, standard hydrogen electrode) though it is more negative than $\mathrm{Mn}\left(\mathrm{Mn}^{2+}:-1.18 \mathrm{~V}\right.$ vs. SHE; $\mathrm{Mn}^{3+}:-0.283 \mathrm{~V}$ vs. SHE), thus improving the formation of a stable and compact $\mathrm{Al}_{2} \mathrm{O}_{3}$ layer. Furthermore, the results showed that aging the samples for 15 min to $5 \mathrm{~h}$ (pre-passivating at a constant passive potential in a $50 \% \mathrm{HNO}_{3}$ ) had a beneficial effect on the stability of the passive film, confirmed by Auger electron spectroscopy (AES) and X-ray photoelectron spectroscopy (XPS) results. It was reported that the passive film is likely made up of bounded water, $\mathrm{Fe}_{2} \mathrm{O}_{3}$ and $\mathrm{FeO}$ (or $\mathrm{Fe}_{3} \mathrm{O}_{4}$ ), $\mathrm{Mn}_{2} \mathrm{O}_{3}$ and $\mathrm{MnO}$ (or $\mathrm{Mn}_{3} \mathrm{O}_{4}$ ), $\mathrm{Al}_{2} \mathrm{O}_{3}$, and metallic state $\mathrm{Fe}, \mathrm{Mn}$, and $\mathrm{Al}$.

The effect of Mn additions on the corrosion properties of Hadfield steel with $\mathrm{Al}$, $\mathrm{Fe}-(19.8-32.5) \mathrm{Mn}-(7.1-10.2) \mathrm{Al}-(0.76-0.99) \mathrm{C}$, in $1 \mathrm{~N} \mathrm{NaOH}, 1 \mathrm{~N} \mathrm{H}_{2} \mathrm{SO}_{4}$, and borate buffer ( $\mathrm{pH}$ 8.4) solutions were analyzed by Cavallini et al. [62]. An increase in $i_{\text {corr }}$ and decrease in $E_{\text {corr }}$ was observed compared to conventional AISI 316 SS. Aluminum acts as a reactive, amphoteric alloying element, which generates a protective oxide layer in the 
pH range 4-9 [63]. However, the oxide layer is unstable in acidic or alkaline solutions, therefore corrosion occurs with hydrogen gas evolution [64].

Tjong et al. studied the corrosion properties of $\mathrm{Fe}-29.7 \mathrm{Mn}-8.7 \mathrm{Al}-1.04 \mathrm{C}$ alloy in $1 \mathrm{~N} \mathrm{H}_{2} \mathrm{SO}_{4}, 1 \mathrm{M} \mathrm{Na}_{2} \mathrm{SO}_{4}(\mathrm{pH} 5.55), 1 \mathrm{M} \mathrm{NaCl}$, and borate buffer solution ( $\mathrm{pH}$ 8.4) and the anodic polarization response was inferior compared to AISI 316 SS [65]. AES was used to investigate the composition of the anodic film. Passivation in $1 \mathrm{~N} \mathrm{H}_{2} \mathrm{SO}_{4}$ acid solution was difficult, however passive film was formed in the $\mathrm{pH}$ range of 5.55-6.10.

The electrochemical behavior of several $\mathrm{Fe}-\mathrm{Mn}-\mathrm{Al}-\mathrm{Si}-\mathrm{C}$ TWIP steels in synthetic mine drainage water, $1 \mathrm{~N} \mathrm{H}_{2} \mathrm{SO}_{4}$, and $3.5 \mathrm{wt} . \% \mathrm{NaCl}$ had been analyzed by Alstetter et al., finding that the studied alloys exhibited lower corrosion resistance than conventional AISI 304 SS [66].

Gau et al. studied the galvanic corrosion of austenitic $\mathrm{Fe}-24.8 \mathrm{Mn}-7.3 \mathrm{Al}-0.12 \mathrm{Si}-0.90 \mathrm{C}$ steel and DP Fe-24.4Mn-9.2Al-0.14Si-0.40C steel alloys in seawater [67]. The measured corrosion rate for AISI 304 SS, austenitic alloy, DP alloy, and mild steel were 0.2, 2.1, 3.0, and $7.3 \mathrm{~mm}_{\text {year }}{ }^{-1}$, respectively. The austenitic alloy exhibited a corrosion rate 10 times larger than AISI 304 SS, while the DP alloy showed a corrosion rate 5 times less than AISI 304 SS. The galvanic series of DP alloys coupled to mild steel and AISI 304 SS was more active than austenitic alloy.

The pitting corrosion behavior studied by Park et al. for DP, TRIP, and TWIP steel in $3.5 \mathrm{wt} . \% \mathrm{NaCl}$ solution examined the high density of single $\mathrm{MnS}$ inclusions generated on DP steel, consequently displaying the lowest resistance to pitting corrosion. Complex MnS on TRIP and complex Mn oxy-sulfide inclusions on TWIP act as galvanic anodes [68].

The study by Ruscak and Perng examined the corrosion behavior of five $\mathrm{Fe}-\mathrm{Mn}-\mathrm{Al}-\mathrm{Cr}-\mathrm{C}$ TWIP steels with ferrite contents $0.5-98 \%$ in $3.5 \mathrm{wt} . \% \mathrm{NaCl}$ solution at room temperature [69]. The passive layer thickness decreased with increasing amounts of ferrite; thus, the ferritic alloy passivation was correlated with the addition of $6.23 \mathrm{wt} . \%$ $\mathrm{Cr}$. The ferrite phase produced pitting at the austenite/ferrite interface. Steel containing ferrite fractions from 46 to $61 \%$ on Fe$-24 \mathrm{Mn}-9 \mathrm{Al}, \mathrm{Fe}-30 \mathrm{Mn}-13 \mathrm{Al}, \mathrm{Fe}-27 \mathrm{Mn}-9 \mathrm{Al}-3 \mathrm{Cr}$, and $\mathrm{Fe}-27 \mathrm{Mn}-13 \mathrm{Al}-6 \mathrm{Cr}$ steel alloys were analyzed by Shih et al. in $3.5 \mathrm{wt} . \% \mathrm{NaCl}$ solution [70]. Pitting corrosion was observed in the ferritic grains and the austenite/ferrite interface. Over a 10-day immersion period, the order of weight loss was $24 \mathrm{Mn}>30 \mathrm{Mn}>$ $3 \mathrm{Cr}>6 \mathrm{Cr}$.

$\mathrm{Fe}-30.5 \mathrm{Mn}-18.68 \mathrm{Al}-1.85 \mathrm{C}$ alloy was studied in $3.5 \mathrm{wt} . \% \mathrm{NaCl}$ solution and showed a passive region, the $E_{\text {pit }}$ was determined to depend on the potential scan rate $(v)$ [71]. Therefore, the results corroborated findings for AISI 304L and 316L SSs in $3.5 \mathrm{wt} . \%$ $\mathrm{NaCl}$ solution and defined a linear relationship between $E_{\mathrm{pit}}$ and the square root of the $v\left(E_{\text {pit }} \alpha v^{\frac{1}{2}}\right)$ [72].

The passive film formation on $\mathrm{Fe}-30 \mathrm{Mn}-9 \mathrm{Al}$ alloy in neutral $1 \mathrm{M} \mathrm{Na}_{2} \mathrm{SO}_{4}$ solution was analyzed by Zhu and Zhang, the duplex structure contained an outer hydrous passive layer and a low valence oxide, internal transition layer between the passive film and alloy matrix [73].

$\mathrm{Fe}-26 \mathrm{Mn}-0.14 \mathrm{C}$ alloy in $3.5 \mathrm{wt} . \% \mathrm{NaCl}$ solution and of $\mathrm{Fe}-24 \mathrm{Mn}-3 \mathrm{Al}-0.1 \mathrm{C}$ alloy in $0.1 \mathrm{M} \mathrm{H}_{2} \mathrm{SO}_{4}$ solution was studied by Hamada and Karjalainen by applying electroless $\mathrm{Ni}-\mathrm{P}$ coatings [74]. For the $26 \mathrm{Mn}$ alloy, an $i_{\text {corr }}$ of $28 \mu \mathrm{A} \mathrm{cm} \mathrm{cm}^{-2}\left(324.8 \mu \mathrm{m}\right.$ year $\left.{ }^{-1}\right)$ and $6 \mu \mathrm{A} \mathrm{cm}^{-2}\left(69.6 \mu \mathrm{m} \mathrm{year}^{-1}\right)$ for the uncoated and coated specimens, respectively. The $\mathrm{Fe}-24 \mathrm{Mn}-3 \mathrm{Al}-0.1 \mathrm{C}$ specimen displayed $i_{\text {corr }}$ values of $3217 \mu \mathrm{A} \mathrm{cm}^{-2}\left(37.3 \times 10^{3} \mu \mathrm{m} \mathrm{year}^{-1}\right)$ and $20 \mu \mathrm{A} \mathrm{cm}^{-2}\left(232 \mu \mathrm{m}\right.$ year $\left.^{-1}\right)$ for the uncoated and coated specimens, respectively. An increase in corrosion resistance by a factor of 4 was observed by the specimens with $\mathrm{Ni}-\mathrm{P}$ coatings. The high $i_{\text {corr }}$ values were attributed to the Mn oxide $(\mathrm{MnO})$ formation, thus reducing the corrosion resistance imparted by its fragile and unstable structure. The $\mathrm{MnO}$ is a basic oxide and reacts with aqueous acids to produce $\mathrm{Mn}^{2+}$ cations and hydrogen evolution; additionally, $\mathrm{Al}$ oxide is unstable below $\mathrm{pH} 4[63,75]$. 
The corrosion properties of the Fe-25Mn-(1-8) Al-0.2C TWIP steels in $3.5 \mathrm{wt} . \%$ $\mathrm{NaCl}$ was investigated by Hamada et al., uniform corrosion and low corrosion resistance were reported. Steels containing up to $6 \mathrm{wt} . \% \mathrm{Al}$ and a homogenous austenite structure displayed scarce pitting, however DP structure ( $\mathrm{Fe}-25 \mathrm{Mn}-8 \mathrm{Al}-0.2 \mathrm{C})$, which includes both ferrite and austenite, showed pitting corrosion occurring preferentially in the $\alpha$-ferrite grains. Moreover, the corrosion resistance of the surface was improved by aging through an anodic passivation treatment in $\mathrm{HNO}_{3}$ acid, due to the $\mathrm{Al}$ incorporated on the surface [76].

The electrochemical behavior of the austenitic $\mathrm{Fe}-29.95 \mathrm{Mn}-8.25 \mathrm{Al}-0.85 \mathrm{C}$ and Fe-25.94Mn-9.33Al-1.45C TWIP alloys, solution-annealed and/or age-treated, was investigated in $3.5 \mathrm{wt} . \% \mathrm{NaCl}$ solution [77]. The tested alloys showed a decreased ability to passivate and a higher anodic passive current density ( $\left.i_{\text {pass }}\right)$ compared to 316 SS. Uniform and pitting corrosion were observed in a $6 \% \mathrm{FeCl}_{3}$ solution under open circuit potential conditions. The observed corrosion rates for the alloys were one order of magnitude higher than conventional $316 \mathrm{SS}$.

Austenitic $\mathrm{Fe}-17 \mathrm{Mn}-3 \mathrm{Al}-0.24 \mathrm{C}, \mathrm{Fe}-21 \mathrm{Mn}-3.5 \mathrm{Al}-0.29 \mathrm{C}$, and $\mathrm{Fe}-27 \mathrm{Mn}-5 \mathrm{Al}-0.57 \mathrm{C}$ steels were studied by Jablonska and Michalik in $3.5 \mathrm{wt} . \% \mathrm{NaCl}$ solution, and in acid rain solution (molar ratio $\mathrm{H}_{2} \mathrm{SO}_{4}: \mathrm{HNO}_{3}: \mathrm{HCl}$ as 1:0.3:0.17) (pH 3.5) [78]. The three steel grades displayed increased corrosion resistance in chloride solution compared to the acid rain solution. The corrosion rate of the $\mathrm{Fe}-27 \mathrm{Mn}-9 \mathrm{Al}$ alloys in $50 \mathrm{wt} . \%$ acetic acid, $5 \mathrm{wt} . \%$ $\mathrm{H}_{2} \mathrm{SO}_{4}$, boiling $\mathrm{HNO}_{3}, 10$ and $40 \mathrm{wt} . \% \mathrm{FeCl}_{3}$, and $3.0 \mathrm{wt} . \% \mathrm{NaCl}$ solution was higher than that of AISI 304 SS $[79,80]$. The corrosion resistance of TWIP steel was enhanced by hotdipping $\mathrm{Al}$ and subsequent thermal diffusion treatment [81], showing the increased ability to repassivate promoted by aluminum. According to the Pourbaix diagram, Al generates a protective and stable $\mathrm{Al}_{2} \mathrm{O}_{3}$ film in the $4-9 \mathrm{pH}$ range [63]. The passive layer of TWIP steels is stable due to the spontaneous passivation caused by $\mathrm{Al}_{2} \mathrm{O}_{3}$ film, which are higher than $\mathrm{Cr}, \mathrm{Mn}$, and Fe [61,82].

Recently, the authors have studied the effect of Mn additions on the corrosion behavior of $\mathrm{Fe}-(21,25,28) \mathrm{Mn}-3 \mathrm{Al}-5 \mathrm{Si}$ steels in a $0.1 \mathrm{M} \mathrm{NaCl}$ solution [83]. The high-resolution XPS spectra in Figure 6 shows the steady Mn enrichment in the outermost oxide scale layer along with a decrease in oxidized Fe species. The absence of $\mathrm{Al}$ enrichment in the oxide explained the detrimental effects of $\mathrm{Mn}$ addition on the corrosion resistance of the high-Mn TWIP steels. The XPS results were consistent with the cyclic potentiodynamic polarization (CPP) curves and electrochemical impedance spectroscopy (EIS) results, and the increase of $\mathrm{Mn}$ in the alloy caused lower polarization resistance $\left(R_{\mathrm{p}}\right)$ values [83]. 

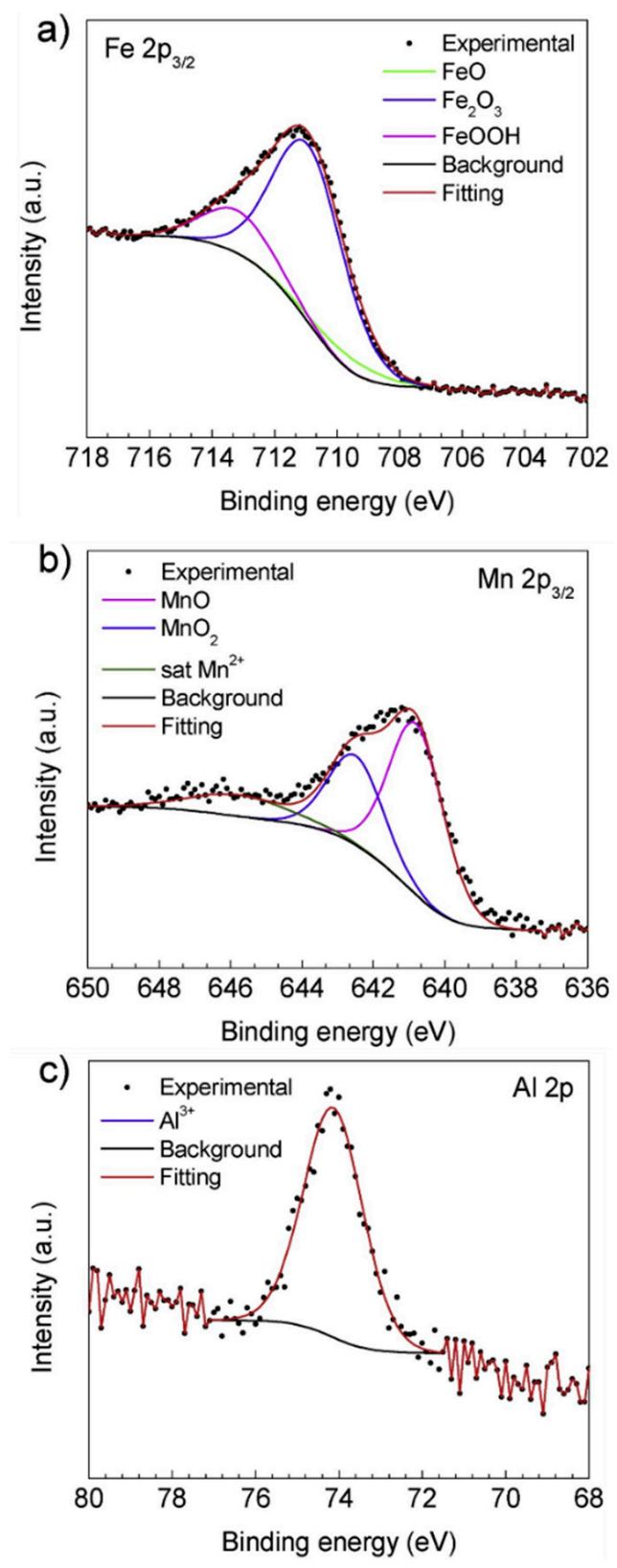

Figure 6. High-resolution XPS spectra for Fe-(21,25,28)Mn-3Al-5Si TWIP steels in $0.1 \mathrm{M} \mathrm{NaCl}$ solution. (a) $\mathrm{Fe} 2 \mathrm{p}_{3 / 2}$, (b) $\mathrm{Cr} 2 \mathrm{p}_{3 / 2}$, and (c) Al 2p [83]. (Reproduced with permission from refs. [83]. Copyright (2019), Elsevier).

\subsection{Effect of $\mathrm{Al}$ and $\mathrm{Cr}$ Alloying on High-Mn TWIP Steel Corrosion}

Alloying with higher amounts of $\mathrm{Cr}$ and decreased $\mathrm{C}$ content has been a significant attempt to improve the corrosion resistance of $\mathrm{Fe}-\mathrm{Mn}-\mathrm{Al}-\mathrm{C}$ steel [83], due to the ability of $\mathrm{Cr}$ and $\mathrm{C}$ to act as ferrite and austenite forming elements, respectively. In this respect, high amounts of $\mathrm{Cr}$ and low $\mathrm{C}$ content leads to a DP microstructure in austenite and ferrite. The $\mathrm{DP} \mathrm{Fe}-\mathrm{Mn}-\mathrm{Al}-\mathrm{Cr}-\mathrm{C}$ exhibits inferior mechanical properties compared to austenitic alloy. Furthermore, the DP alloy displays issues in hot forming processes for alloys including $\mathrm{Fe}-(21.5-27.7) \mathrm{Mn}-(8.9-9.9) \mathrm{Al}-(3.1-6.2) \mathrm{Cr}-(0.33-0.42) \mathrm{C}$ [83]. Tuan et al. studied the corrosion behavior of as-quenched austenitic $\mathrm{Fe}-30 \mathrm{Mn}-7 \mathrm{Al}-(0,3,6,9) \mathrm{Cr}-1 \mathrm{C}$ alloys in a $3.5 \mathrm{wt} . \% \mathrm{NaCl}$ solution [84]. The $\mathrm{Cr}$ addition showed an enhancement of $E_{\text {pit }}$ up to $6 \mathrm{wt} . \% \mathrm{Cr}, 9 \mathrm{wt} . \% \mathrm{Cr}$ showed a decreased $E_{\text {pit }}$ attributed to the formation of the intermetallic K-carbide $(\mathrm{Fe}, \mathrm{Mn}, \mathrm{Cr})_{7} \mathrm{C}_{3}$. 
The effect of $\mathrm{Cr}$ additions on the passivity of $\mathrm{Fe}-30 \mathrm{Mn}-5 \mathrm{Al}-(0,3,6,9) \mathrm{Cr}-0.5 \mathrm{C}$ highMn TWIP steels under thermo-mechanical processing (TMP) and in deaerated $0.1 \mathrm{M} \mathrm{NaCl}$ solution was studied by the authors [85]. Chromium addition showed a beneficial effect, however high $\mathrm{Cr}$ content was shown to cause phase-segregation, thus reducing the corrosion resistance [86]. The results indicate that TMP diminishes corrosion resistance.

Hamada et al. reported that $\mathrm{Al}$ and $\mathrm{Cr}$ additions in $\mathrm{Fe}-30 \mathrm{Mn}-4 \mathrm{Al}-4 \mathrm{Cr}-0.26 \mathrm{C}$ or $\mathrm{Fe}-30 \mathrm{Mn}-8 \mathrm{Al}-6 \mathrm{Cr}-0.25 \mathrm{C}$ TWIP alloys increased the corrosion resistance significantly, particularly after anodic passivation ageing in an oxidizing solution $\left(\mathrm{HNO}_{3}\right)$. Steels containing $\mathrm{Cr}$ have been shown to passivate with enrichment of $\mathrm{Al}$ and $\mathrm{Cr}$ and a depletion of Fe and Mn [76]. Hamada et al. have reported that high-Al TWIP steels exhibited salt-film precipitation as a passivation mechanism [82]. A comparison of corrosion properties of $\mathrm{Fe}-25 \mathrm{Mn}-(5-8) \mathrm{Al}-0.2 \mathrm{C}, \mathrm{Fe}-30 \mathrm{Mn}-(4-8) \mathrm{Al}-(14-16) \mathrm{Cr}-0.2 \mathrm{C}$, and AISI $304 \mathrm{SS}$ alloys in $5-50 \% \mathrm{HNO}_{3}$ acid solution was presented [82]. The anodic polarization curves depict an active-to-passive peak, followed by a stable passivation region. In the transpassive region, a breakdown $E_{\text {pit }}$, a secondary passivation region, and the evolution of oxygen are observed. At the beginning of the transpassive region peak, formation of $\mathrm{Fe}, \mathrm{Al}$, and $\mathrm{Cr}$ oxyhydroxides may take place. The passivation current of $\mathrm{Fe}-30 \mathrm{Mn}-8 \mathrm{Al}-6 \mathrm{Cr}$ is lower than that of AISI $304 \mathrm{SS}$, thus the passive film of $\mathrm{Fe}-30 \mathrm{Mn}-8 \mathrm{Al}-6 \mathrm{Cr}$ steel is more stable, attributed to the high passivity properties of $\mathrm{Al}$, which are higher than $\mathrm{Cr}$ and considerably higher than those of $\mathrm{Mn}$ and Fe [82]. High current density oscillations for the $\mathrm{Fe}-25 \mathrm{Mn}-8 \mathrm{Al}$ alloy can be observed in the beginning of passive region and after the Flade potential $\left(E_{\mathrm{f}}\right)$, the potential at active-passive transition, i.e., the active-passive region. Two oscillationtype regimens were determined by Hamada et al., the first high-frequency oscillations were associated with the mass transfer-controlled plateau connected with the formationdisappearance of a porous salt film. The low-frequency-type oscillations, which consisted of periods of seconds to minutes, were associated with the relaxation processes, according to previous results in the literature [87]. Therefore, the passivation of $\mathrm{Fe}-25 \mathrm{Mn}-8 \mathrm{Al}$ steel was ascribed to salt film precipitation, contrary to the spontaneous oxide film formation in a Cr-bearing steel, as previously stated. In another study, the corrosion behavior of austenitic $\mathrm{Fe}-\mathrm{Mn}-\mathrm{Al}-\mathrm{Cr}-\mathrm{C}$ twinning-induced plasticity (TWIP) and microband-induced plasticity (MBIP) steels exposed to $3.5 \mathrm{wt} . \% \mathrm{NaCl}$ and $10 \mathrm{wt} . \% \mathrm{NaOH}$ solutions was studied [88]. Figure 7 presents the potentiodynamic polarization curves for two TWIP steels with a composition of $\mathrm{Fe}-22.6 \mathrm{Mn}-6.3 \mathrm{Al}-3.1 \mathrm{Cr}-0.68 \mathrm{C}$ and $\mathrm{Fe}-28 \mathrm{Mn}-5.2 \mathrm{Al}-5.1 \mathrm{Cr}-2.8 \mathrm{Si}-0.95 \mathrm{C}$ and a MBIP steel with a composition of $\mathrm{Fe}-30 \mathrm{Mn}-8.5 \mathrm{Al}-3.2 \mathrm{Cr}-1.1 \mathrm{Mo}-1.0 \mathrm{C}$ in both media, 3.5 wt. $\% \mathrm{NaCl}$ and $10 \mathrm{wt} . \% \mathrm{NaOH}$ solutions [88]. Figure 7 shows a decreasing trend in the cathodic kinetics as the content of Mn increases. This was related to the catalytic properties of the TWIP alloys towards the oxygen reduction reaction (ORR). In the alkaline media, the anodic branch was found to be stable showing a lack of current density oscillations related to the spontaneous formation of $\mathrm{Al}_{2} \mathrm{O}_{3}$ film that imparted passivity. Contrarily, in the neutral area, these oscillations were observed, confirming the salt-film precipitation passivation mechanism [88]. 


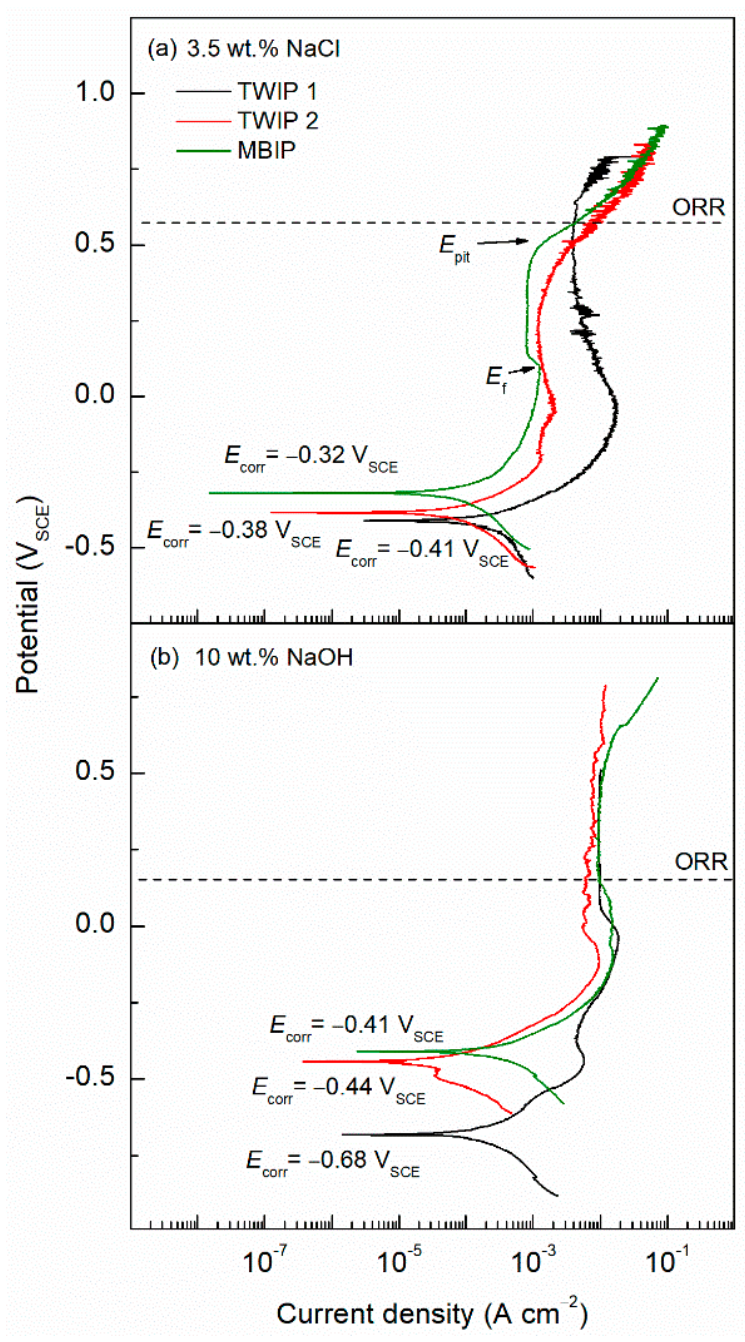

Figure 7. Polarization curves for two TWIP steels $(\mathrm{Fe}-22.6 \mathrm{Mn}-6.3 \mathrm{Al}-3.1 \mathrm{Cr}-0.68 \mathrm{C}$ and $\mathrm{Fe}-28 \mathrm{Mn}-5.2 \mathrm{Al}-5.1 \mathrm{Cr}-2.8 \mathrm{Si}-0.95 \mathrm{C})$ and a microband-induced plasticity (MBIP) steel (Fe-30Mn-8.5Al-3.2Cr-1.1Mo-1.0C) in: (a) 3.5 wt.\% NaCl solution, and (b) 10 wt.\% $\mathrm{NaOH}$ solution [88].

Mujica et al. examined the effect of $\mathrm{Cr}$ in the formation of passive layers on $\mathrm{Fe}-25 \mathrm{Mn}-12 \mathrm{Cr}-0.3 \mathrm{C}-0.4 \mathrm{~N}$ alloy in $0.5 \mathrm{M} \mathrm{H}_{2} \mathrm{SO}_{4}$ solution $[50,89]$. The $\mathrm{Cr}, \mathrm{C}$, and $\mathrm{N}$ enriched steel displays passivity and $i_{\text {corr }}$ values five orders of magnitude lower than the $\mathrm{Fe}-22 \mathrm{Mn}-0.6 \mathrm{C}$ steel.

The corrosion behavior and passivation of $\mathrm{Fe}-(17-31) \mathrm{Mn}-(1-9) \mathrm{Al}-(1-7) \mathrm{Cr}$ alloys in $1 \mathrm{M} \mathrm{Na}_{2} \mathrm{SO}_{4}, 3.5 \mathrm{wt} . \% \mathrm{NaCl}$ and rainwater solutions were investigated by $\mathrm{Zhu}$ and Zhang [90]. The increased content of $\mathrm{Al}$ produced increased $E_{\text {corr }}$ values and decreased $i_{\text {corr }}$ values, however increased $\mathrm{Mn}$ counteracted the $\mathrm{Al}$ and no passivation was observed [90]. The passive film formed on the $\mathrm{Fe}-24 \mathrm{Mn}-4 \mathrm{Al}-5 \mathrm{Cr}$ alloy in $1 \mathrm{M} \mathrm{Na}_{2} \mathrm{SO}_{4}$ solution was comprised of three parts: bounded water and hydroxides present at the surface; the outer portion of film made up of a mixture of $\mathrm{Fe}, \mathrm{Mn}, \mathrm{Cr}$, and $\mathrm{Al}$ oxides; and a transition region consisting of low valence oxides and metallic $\mathrm{Fe}, \mathrm{Mn}, \mathrm{Cr}$, and $\mathrm{Al}$ between the passive film and the matrix, see Figure 8 . The corrosion resistance was imparted by the barrier film of bounded water, hydroxides, and oxides of $\mathrm{Cr}, \mathrm{Al}$, and $\mathrm{Fe}$ [91]. 

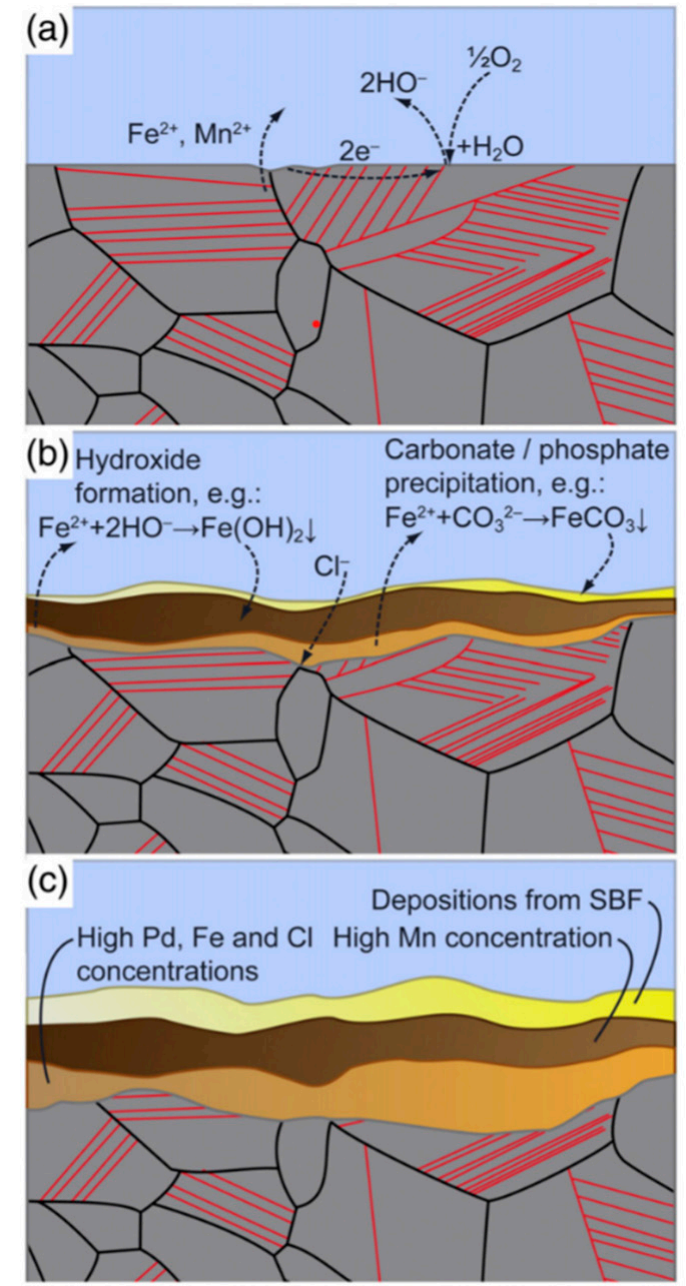

Figure 8. Schematic illustration of the degradation process and the formation of degradation products for TWIP-1Pd alloys: (a) Initiation of the corrosion reaction: The anodic partial reactions are the metal oxidation, whereas the cathodic partial reaction is oxygen reduction, (b) formation of hydroxides/oxides, and precipitation of carbonates and phosphates that comprise the degradation products. $\mathrm{Cl}^{-}$ions diffuse to the surface, causing localized attacks, and (c) further build-up of degradation products. The Pd remains in the layer close to the sample surface and acts as a macrogalvanic element to increase degradation [92]. (Reproduced with permission from refs. [92]. Copyright (2013), Elsevier).

Several corrosion protection strategies have been used including alloying, thermal treatments, and coatings to improve corrosion resistance of the $\mathrm{Fe}-\mathrm{Mn}-\mathrm{Al}-\mathrm{C}$ TWIP steels [82,93-100]. As-quenched, austenitic $\mathrm{Fe}-30 \mathrm{Mn}-9 \mathrm{Al}-(3,5,6.5,8) \mathrm{Cr}-1 \mathrm{C}$ alloys in 3.5 wt. \% $\mathrm{NaCl}$ solution showed passivation and lower $E_{\text {corr }}$ and $E_{\text {pit }}$ values as $\mathrm{Cr}$ content increased above $5 \mathrm{wt} . \%$, yet the $E_{\text {corr }}$ and $E_{\text {pit }}$ decrease for $\mathrm{Cr}$ concentration up to $6.5 \mathrm{wt} . \%$ and $8 \mathrm{wt}$.\% due to $\mathrm{k}$-carbide $(\mathrm{Fe}, \mathrm{Mn}, \mathrm{Cr})_{7} \mathrm{C}_{3}$ [101]. The alloy was aged using an anodic passivation current to promote a thick, protective passive film [74].

Tsay et al. studied the corrosion behavior of $\mathrm{Fe}-28 \mathrm{Mn}-9 \mathrm{Al}-6 \mathrm{Cr}-1.8 \mathrm{C}$ alloy in $3.5 \mathrm{wt} . \% \mathrm{NaCl}$ [102]. Due to $\mathrm{Cr}$ and $\mathrm{Al}$ oxide formation, the $E_{\text {corr }}$ and $E_{\text {pit }}$ were $-538 \mathrm{mV}$ and $-25 \mathrm{mV}$, respectively, significantly higher than $-920 \mathrm{mV}(\sim-789 \mathrm{mV})$ and $-500 \mathrm{mV}$ $(\sim-240 \mathrm{mV})$ for $E_{\text {corr }}$ and $E_{\text {pit }}$, respectively, of $\mathrm{Fe}-28 \mathrm{Mn}-9 \mathrm{Al}-6 \mathrm{Cr}-1.8 \mathrm{C}$ alloy. The Auger depth profiles of the passive film are shown in Figure $9 a-d$ for the alloys containing (a) $0 \mathrm{Cr},(\mathrm{b}) 3 \mathrm{Cr}$, (c) $6 \mathrm{Cr}$ and (d) $8 \mathrm{Cr}$. For the alloys with (b) $3 \mathrm{Cr}$, (c) $6 \mathrm{Cr}$, and (d) $8 \mathrm{Cr}$, broad $\mathrm{Al}, \mathrm{Cr}$, and $\mathrm{O}$ peaks are observed at a depth of $0-2 \mathrm{~mm}$. Thus, the presence of $\mathrm{Al}$ and $\mathrm{Cr}$ oxides in samples (b) and (c) may explain the high corrosion resistance, however sample 
(d) with the highest concentration of $\mathrm{Cr}$ showed coarse, $\mathrm{Cr}$-rich, $(\mathrm{Fe}, \mathrm{Mn}, \mathrm{Cr})_{7} \mathrm{C}_{3} \mathrm{~K}$-carbides which caused a significant decrease in $E_{\text {corr }}$ and $E_{\text {pit }}$ values. The presence of a layer of $\mathrm{Cr}$ and $\mathrm{Al}$ oxides in the passive film may play an important role in improving the corrosion resistance characteristics of alloys (b) $3 \mathrm{Cr}$ through (c) $6 \mathrm{Cr}$. However, the formation of the coarse $\mathrm{Cr}$-rich $(\mathrm{Fe}, \mathrm{Mn}, \mathrm{Cr})_{7} \mathrm{C}_{3} \mathrm{~K}$-carbides resulted in a drastic decrease in the $E_{\mathrm{corr}}$ and $E_{\mathrm{pit}}$ values of alloy (d) $8 \mathrm{Cr}$.

(a)

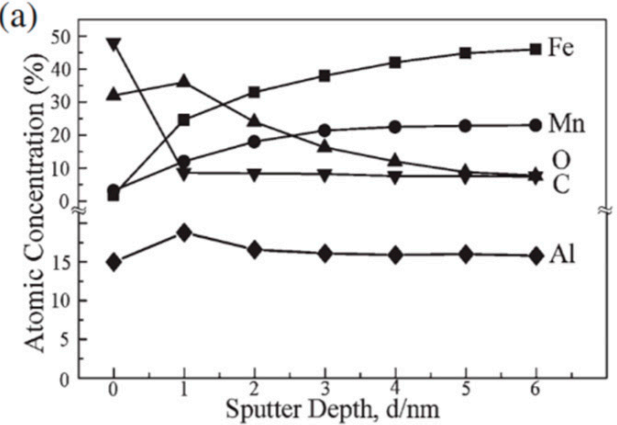

(c)

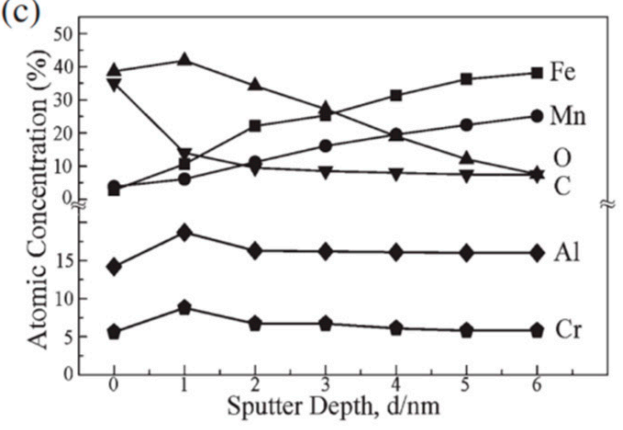

(b)

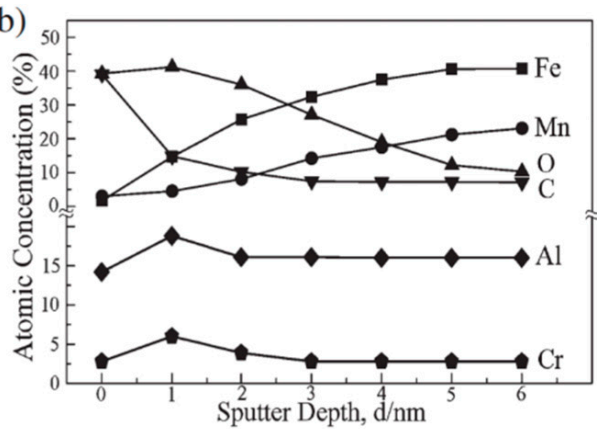

(d)

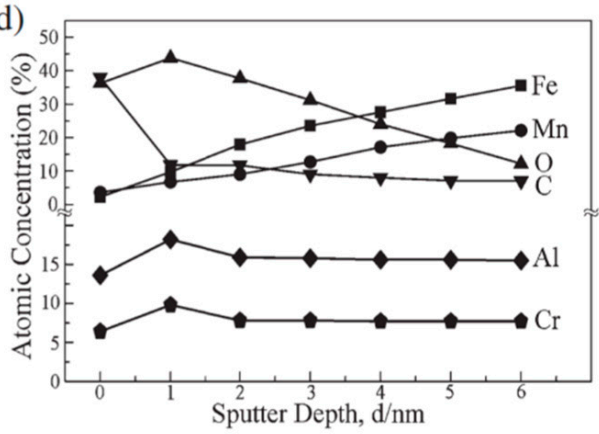

Figure 9. Auger depth profiles of the passive film present on Fe-28Mn-9Al-6Cr-1.8C alloy (a) $0 \mathrm{Cr}$, (b) 3Cr, (c) 6Cr, and (d) 8Cr [102]. (Reproduced with permission from refs. [102]. Copyright (2010), Materials transactions).

$\mathrm{Fe}-\mathrm{Mn}-\mathrm{Al}$ alloys, which contain significant amounts of $\mathrm{Mn}(>30 \mathrm{wt} . \%)$ and $\mathrm{Al}$ ( $>8 \mathrm{wt} . \%$ ) demonstrate difficult workability, forming, and welding. Due to the requirement to combine $\mathrm{Al}$ with $\mathrm{Cr}$ to enhance the passive layer, it is cost efficient to reduce $\mathrm{Cr}$ additions to $\mathrm{Fe}-\mathrm{Mn}-\mathrm{Al}$ alloys [103]. The outer layer of the passive film for $\mathrm{Fe}-24 \mathrm{Mn}-3 \mathrm{Al}-7 \mathrm{Cr}$ in $1 \mathrm{M} \mathrm{Na}_{2} \mathrm{SO}_{4}$ solution was found to be enriched in Fe oxides, while the inner portion was enriched in $\mathrm{Cr}$ and $\mathrm{Al}$. Figure 10 shows the different distributions of $\mathrm{Cr}$ and $\mathrm{Al}$ in the passive film in strong oxidizing $50 \% \mathrm{HNO}_{3}$ solution compared to neutral $\mathrm{Na}_{2} \mathrm{SO}_{4}$ solution. The maximum $\mathrm{O}$ concentration is determined by the amounts of $\mathrm{Cr}$ and $\mathrm{Al}$. XPS results showed the majority oxide constituents in the passive film to be $\mathrm{Cr}_{2} \mathrm{O}_{3}, \mathrm{Al}_{2} \mathrm{O}_{3}$, and $\mathrm{Fe}_{2} \mathrm{O}_{3}$, which display good corrosion resistance, while Mn oxides in the film (primarily $\mathrm{MnO}_{2}$ ) reduces the corrosion resistance due to their fragile and unstable structure [103], as indicated above in Figure 8. 


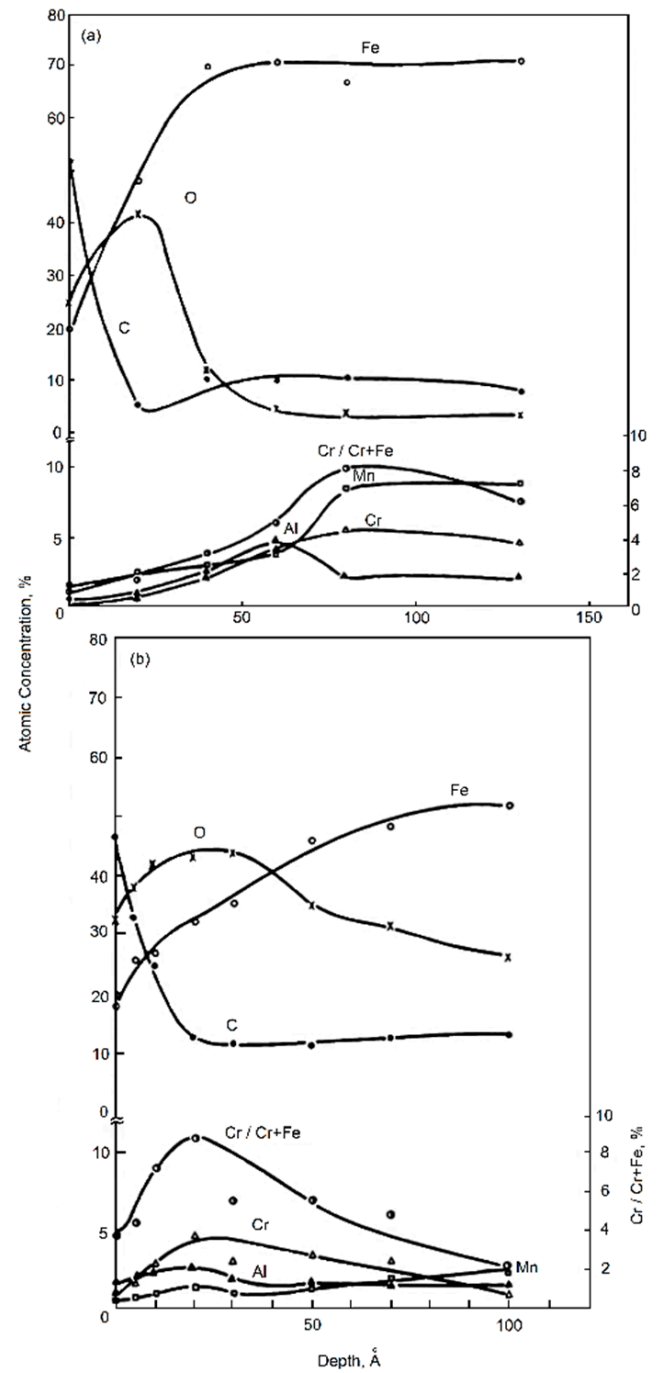

Figure 10. Auger depth profiles for passive film of Fe-24Mn-3Al-7Cr: (a) Formed in $1 \mathrm{M} \mathrm{Na}_{2} \mathrm{SO}_{4}$ at $500 \mathrm{mV}_{\mathrm{SCE}}$, and (b) formed in $50 \% \mathrm{HNO}_{3}$ at $1050 \mathrm{mV}_{\mathrm{SCE}}$ [103]. (Reproduced with permission from refs. [103]. Copyright (1997), Taylor \& Francis).

The corrosion properties of austenitic $\mathrm{Fe}-(23-30) \mathrm{Mn}, \mathrm{Fe}-(23-30) \mathrm{Mn}-(2.8-8.2) \mathrm{Al}$, $\mathrm{Fe}-(23-30) \mathrm{Mn}-(4.9-6.9) \mathrm{Cr}$, and $\mathrm{Fe}-(23-30) \mathrm{Mn}-(2.8-8.2) \mathrm{Al}-(4.9-6.9) \mathrm{Cr}$ alloys have been studied in various aqueous solutions $\mathrm{pH}$ from -0.8 to 15.3 using electrochemical, AES, and XPS results [97]. Fe-Mn binary alloys were passivated in $10-50 \% \mathrm{NaOH}$ solutions; additions of $\mathrm{Al}$ and $\mathrm{Cr}$, however, showed no significant corrosion resistance increase in $\mathrm{HNO}_{3}$ or $\mathrm{Na}_{2} \mathrm{SO}_{4}$ solutions. All of the $\mathrm{Fe}-\mathrm{Mn}$-based alloys showed no passivation in neither $10 \% \mathrm{HCl}$ nor $3.5 \mathrm{wt}$ \% $\mathrm{NaCl}$ solutions. The $\mathrm{Fe}-\mathrm{Mn}$ alloys containing $\mathrm{Al}, \mathrm{Cr}$, or a combination of the two showed passivation in $10-50 \% \mathrm{HNO}_{3}, 1 \mathrm{M} \mathrm{Na}_{2} \mathrm{SO}_{4}$, and rainwater solutions. Bound water and hydroxides were present on the outermost portion of the passive film, while the oxides of $\mathrm{Fe}, \mathrm{Al}, \mathrm{Cr}$, and $\mathrm{Mn}$ were found on the inner surface of the film. Overall, $\mathrm{Fe}-\mathrm{Mn}$-based alloys showed passivation in oxidizing acid, neutral, and basic solutions, however it did not passivate in reducing acid or active chloride solutions [97]. Tables 2 and 3 summarize corrosion rate $\left(v_{\text {corr }}\right)\left(\mu\right.$ year $\left.^{-1}\right)$ values for high-Mn TWIP steel containing $\mathrm{Al}$, and $\mathrm{Al}$ and $\mathrm{Cr}$, respectively. 
Table 2. Corrosion rate $\left(v_{\text {corr }}\right)\left(\mu\right.$ year $\left.^{-1}\right)$ values for high-Mn TWIP steels with aluminum alloying.

\begin{tabular}{|c|c|c|c|}
\hline Alloy & Electrolyte & $v_{\text {corr }} \mu \mathrm{m}$ year $^{-1}$ & Reference \\
\hline Fe-25Mn-5Al-0.22C & $5 \% \mathrm{HNO}_{3}$ & 1090 & [82] \\
\hline Fe-25Mn-8Al-0.20C & $5 \% \mathrm{HNO}_{3}$ & 835 & [82] \\
\hline Fe-25Mn-5Al-0.22C & $10 \% \mathrm{HNO}_{3}$ & 1450 & [82] \\
\hline Fe-25Mn-8Al-0.20C & $10 \% \mathrm{HNO}_{3}$ & 974 & [82] \\
\hline Fe-25Mn-5Al-0.22C & $30 \% \mathrm{HNO}_{3}$ & 1740 & [82] \\
\hline Fe-25Mn-8Al-0.20C & $30 \% \mathrm{HNO}_{3}$ & 1508 & [82] \\
\hline Fe-25Mn-5Al-0.22C & $50 \% \mathrm{HNO}_{3}$ & 2969 & [82] \\
\hline Fe-25Mn-8Al-0.20C & $50 \% \mathrm{HNO}_{3}$ & 742 & [82] \\
\hline $\mathrm{Fe}-30 \mathrm{Mn}-8 \mathrm{Al}-1 \mathrm{C}$ & $10 \% \mathrm{HCl}$ & $126 \times 10^{3}$ & [97] \\
\hline Fe-25Mn-5Al-0.15C & $10 \% \mathrm{HCl}$ & 74,160 & [97] \\
\hline Fe-25Mn-5Al-0.15C & $30 \% \mathrm{HNO}_{3}$ & 345,307 & [61] \\
\hline Fe-25Mn-5Al-0.15C & $10 \% \mathrm{HCl}$ & 74,160 & [61] \\
\hline Fe-25Mn-5Al-0.15C & $30 \% \mathrm{NaOH}$ & 88.1 & [61] \\
\hline Fe-25Mn-5Al-0.15C & $10 \% \mathrm{Na}_{2} \mathrm{SO}_{4}+\mathrm{HNO}_{3}$ & $212 \times 10^{3}$ & [61] \\
\hline Fe-25Mn-5Al-0.15C & $3.5 \% \mathrm{NaCl}$ & 133.3 & [61] \\
\hline Fe-19.8Mn-7.1Al-(0.76-0.99)C & $1 \mathrm{~N} \mathrm{NaOH}$ & 81.2 & [62] \\
\hline Fe-23.3Mn-7.1Al-(0.76-0.99)C & $1 \mathrm{~N} \mathrm{H}_{2} \mathrm{SO}_{4}$ & 69.6 & [62] \\
\hline Fe-30.5Mn-7.1Al-(0.76-0.99)C & Borate buffer pH 8.4 & 232 & [62] \\
\hline Fe-28Mn-9Al & Mine water (pH 3.5) & 150 & [66] \\
\hline Fe-30Mn-14Al & Salt water & 190 & [66] \\
\hline Fe-30Mn-9Al-1C & $1 \mathrm{~N} \mathrm{H}_{2} \mathrm{SO}_{4}$ & $195 \times 10^{3}$ & [66] \\
\hline $\mathrm{Fe}-24.8 \mathrm{Mn}-7.3 \mathrm{Al}-0.90 \mathrm{C}$ & Artificial seawater & 33.2 & [67] \\
\hline Fe-24.4Mn-9.2Al-0.40C & Artificial seawater & 48.3 & [67] \\
\hline Fe-28Mn-10Al-1C & $3.5 \% \mathrm{NaCl}$ & 11.6 & [69] \\
\hline Fe-24Mn-9Al-0.40C & $3.5 \% \mathrm{NaCl}$ & 580 & [70] \\
\hline Fe-30.7Mn-13.03Al-0.44C & $3.5 \% \mathrm{NaCl}$ & 570 & [70] \\
\hline Fe-26.6Mn-9.29Al-0.43C & $3.5 \% \mathrm{NaCl}$ & 200 & [70] \\
\hline Fe-30.5Mn-8.68Al-1.85C & $3.5 \% \mathrm{NaCl}$ & 912 & [71] \\
\hline Fe-30Mn-9Al & $1 \mathrm{M} \mathrm{Na}_{2} \mathrm{SO}_{4}$ & 34.8 & [73] \\
\hline Fe-30Mn-9Al-1.8C & $3.5 \% \mathrm{NaCl}$ & 0.9 & [99] \\
\hline
\end{tabular}

Table 3. Corrosion rate $\left(v_{\text {corr }}\right)\left(\mu \mathrm{m}_{\text {year }}{ }^{-1}\right)$ values for high-Mn TWIP steels with aluminum and chromium elements.

\begin{tabular}{|c|c|c|c|}
\hline Alloy & Electrolyte & $v_{\text {corr }} \mu \mathrm{m}$ year $^{-1}$ & Reference \\
\hline Fe-30Mn-4Al-14Cr & $5 \% \mathrm{HNO}_{3}$ & 174 & [82] \\
\hline Fe-30Mn-8Al-16Cr & $5 \% \mathrm{HNO}_{3}$ & 17.4 & [82] \\
\hline Fe-30Mn-4Al-14Cr & $10 \% \mathrm{HNO}_{3}$ & 232 & [82] \\
\hline Fe-30Mn-8Al-16Cr & $10 \% \mathrm{HNO}_{3}$ & 40.6 & [82] \\
\hline Fe-30Mn-4Al-14Cr & $30 \% \mathrm{HNO}_{3}$ & 522 & [82] \\
\hline Fe-30Mn-8Al-16Cr & $30 \% \mathrm{HNO}_{3}$ & 92.8 & [82] \\
\hline $\mathrm{Fe}-30 \mathrm{Mn}-4 \mathrm{Al}-14 \mathrm{Cr}$ & $50 \% \mathrm{HNO}_{3}$ & 60.3 & [82] \\
\hline Fe-30Mn-8Al-16Cr & $50 \% \mathrm{HNO}_{3}$ & 1.2 & [82] \\
\hline $\mathrm{Fe}-24 \mathrm{Mn}-3 \mathrm{Al}-7 \mathrm{Cr}$ & $1 \mathrm{M} \mathrm{Na}{ }_{2} \mathrm{SO}_{4}$ & 23.4 & [103] \\
\hline $\mathrm{Fe}-24 \mathrm{Mn}-3 \mathrm{Al}-7 \mathrm{Cr}$ & $10 \% \mathrm{HNO}_{3}$ & $0.3 \times 10^{3}$ & [103] \\
\hline $\mathrm{Fe}-24 \mathrm{Mn}-3 \mathrm{Al}-7 \mathrm{Cr}$ & $30 \% \mathrm{HNO}_{3}$ & $0.3 \times 10^{3}$ & [103] \\
\hline Fe-24Mn-3Al-7Cr & $50 \% \mathrm{HNO}_{3}$ & 110 & [103] \\
\hline $\mathrm{Fe}-24 \mathrm{Mn}-3 \mathrm{Al}-7 \mathrm{Cr}$ & $10 \% \mathrm{NaOH}$ & 10.4 & [103] \\
\hline Fe-24Mn-3Al-7Cr & $30 \% \mathrm{NaOH}$ & 23.2 & [103] \\
\hline $\mathrm{Fe}-24 \mathrm{Mn}-3 \mathrm{Al}-7 \mathrm{Cr}$ & $50 \% \mathrm{NaOH}$ & 11.6 & [103] \\
\hline $\mathrm{Fe}-24 \mathrm{Mn}-3 \mathrm{Al}-7 \mathrm{Cr}$ & $10 \% \mathrm{HCl}$ & $0.1 \times 10^{3}$ & [103] \\
\hline Fe-24Mn-3Al-7Cr & $3.5 \% \mathrm{NaCl}$ & 98.6 & [103] \\
\hline Fe-28Mn-9Al-(0-8)Cr-1.8C & $3.5 \% \mathrm{NaCl}$ & 34.8 & [102] \\
\hline Fe-21Mn-10Al-6Cr & $3.5 \% \mathrm{NaCl}$ & 10.4 & [69] \\
\hline Fe-27Mn-9Al-3Cr & $3.5 \% \mathrm{NaCl}$ & 92.8 & [70] \\
\hline $\mathrm{Fe}-27 \mathrm{Mn}-9 \mathrm{Al}-6 \mathrm{Cr}$ & $3.5 \% \mathrm{NaCl}$ & 92.8 & [70] \\
\hline Fe-26.4Mn-2.74Al-1.13Cr-0.32C & $3.5 \% \mathrm{NaCl}$ & 783.3 & [100] \\
\hline
\end{tabular}




\subsection{Effect of Al and Si Alloying on High-Mn TWIP Steel Corrosion}

The corrosion resistance of $\mathrm{Fe}-\mathrm{Mn}-\mathrm{Al}-\mathrm{Si}-\mathrm{C}$ TWIP steel alloys in tap water, synthetic mine, $3.5 \mathrm{wt} . \% \mathrm{NaCl}$, and $\mathrm{H}_{2} \mathrm{SO}_{4}$ solutions and the effects with $\mathrm{Si}$ additions have been investigated in literature [66,104]. It has been reported that $\mathrm{Si}$ can increase corrosion resistance of the alloy. The role of $\mathrm{Si}$ in $\mathrm{Fe}-\mathrm{Mn}-\mathrm{Al}$ alloys was suggested to act as a solid solution strengthener $[105,106]$. The principal restriction in industrial applications of $\mathrm{Fe}-\mathrm{Mn}-\mathrm{Al}-\mathrm{Si}-\mathrm{C}$ alloys is their poor corrosion resistance in severely aggressive media $[66,88]$. However, Wang and Beck reported that the $\mathrm{Fe}-30.5 \mathrm{Mn}-10.4 \mathrm{Al}-1.3 \mathrm{Si}-1.01 \mathrm{C}$ alloy presented a higher corrosion resistance than the $\mathrm{Fe}-18.59 \mathrm{Cr}-0.63 \mathrm{Ni}-1.07 \mathrm{Ti}-0.08 \mathrm{C}$ steel in a marine environment [107].

Kannan et al., in a comparative study, examined the corrosion properties of austenitic $\mathrm{Fe}-29 \mathrm{Mn}-3.1 \mathrm{Al}-1.4 \mathrm{Si}-0.05 \mathrm{C}$ and interstitial-free (IF)-type steel using immersion and polarization tests in $3.5 \mathrm{wt} . \% \mathrm{NaCl}$ and $0.1 \mathrm{M} \mathrm{H}_{2} \mathrm{SO}_{4}$ solutions [108]. High-Mn TWIP steel demonstrated lower corrosion resistance than IF steel in chloride and acid solutions, however the corrosion resistance of austenitic high-Mn steel in $3.5 \mathrm{wt} . \% \mathrm{NaCl}$ was higher than in $0.1 \mathrm{M} \mathrm{H}_{2} \mathrm{SO}_{4}$.

The corrosion behavior of $\mathrm{Fe}-32.7 \mathrm{Mn}-6.59 \mathrm{Al}-1.26 \mathrm{Si}-0.25 \mathrm{C}$, and $\mathrm{Fe}-32.5 \mathrm{Mn}-$ 8.54Al-1.31Si-0.54C alloys was studied by Lins et al. in $1 \mathrm{~N} \mathrm{H}_{2} \mathrm{SO}_{4}, 3.0 \mathrm{wt} . \% \mathrm{NaCl}$, lactic acid, gasoline, fuel alcohol, and boiler water. Manganese exhibits poor passivity properties; however, it forms an unstable $\mathrm{MnO}$ film, increase $i_{\text {corr }}$ and decreased $E_{\text {corr }}$ values [109-111]. Abuzriba and Musa examined the electrochemical response of three austenitic $\mathrm{Fe}-33 \mathrm{Mn}-9 \mathrm{Al}-1.4 \mathrm{Si}-0.9 \mathrm{C}, \mathrm{Fe}-29 \mathrm{Mn}-8.6 \mathrm{Al}-2.7 \mathrm{Si}-0.7 \mathrm{C}$, and $\mathrm{Fe}-24 \mathrm{Mn}-$ 7.3Al-2Si-1C alloys in $3.5 \mathrm{wt} . \% \mathrm{NaCl}$ solution [112]. The alloys were determined to be unsuitable as substitutes for conventional SS.

Lean Mn TWIP steels $\mathrm{Fe}-18 \mathrm{Mn}-1.5 \mathrm{Al}-0.6 \mathrm{C}$, Fe $-15 \mathrm{Mn}-0.5 \mathrm{Al}-1.5 \mathrm{Si}-0.7 \mathrm{C}$, and $\mathrm{Fe}-12 \mathrm{Mn}-2.0 \mathrm{Si}-0.9 \mathrm{C}$ in seawater with a flowing condition of $3.0 \mathrm{~cm} \mathrm{~s}^{-1}$ were studied by Moon et al. [113]. The most noble value of $E_{\mathrm{corr}}$ was the $18 \mathrm{Mn}$ alloy, and $12 \mathrm{Mn}$ showed the least noble $E_{\mathrm{corr}}$, thus indicating that $18 \mathrm{Mn}$ presented the highest corrosion resistance. The polarization results indicate a passivity plateau width of 500,380 , and $250 \mathrm{mV}$ for $18 \mathrm{Mn}$, $15 \mathrm{Mn}$, and $12 \mathrm{Mn}$, respectively.

The corrosion properties of $\mathrm{Fe}-29 \mathrm{Mn}-3.1 \mathrm{Al}-1.4 \mathrm{Si}-0.05 \mathrm{C}$ steel compared to IF steel in acidic $\left(0.1 \mathrm{M} \mathrm{H}_{2} \mathrm{SO}_{4}\right)$, alkaline $(0.1 \mathrm{M} \mathrm{NaOH})$, and chloride-containing ( $\left.3.5 \mathrm{wt} . \% \mathrm{NaCl}\right)$ environments were studied by Kannan et al. using immersion and polarization experiments [107]. The alloy exhibited considerably lower corrosion resistance in acidic solution compared to IF steel. Despite the lower corrosion resistance of $\mathrm{Fe}-\mathrm{Mn}-\mathrm{Al}-\mathrm{Si}-\mathrm{C}$ steel compared to IF steel, the difference was not substantial. The $\mathrm{Fe}-\mathrm{Mn}-\mathrm{Al}-\mathrm{Si}-\mathrm{C}$ steel, however, showed no significant difference in the corrosion resistance compared with that of IF steel; furthermore, it exhibited substantially high corrosion resistance than in acidic and chloride solution. High corrosion attack of $\mathrm{Fe}-\mathrm{Mn}-\mathrm{Al}-\mathrm{Si}-\mathrm{C}$ steel exposed to acidic solution was observed compared to the alkaline and chloride solutions, which is consistent with the corrosion measurement data. The scanning electron microscopy (SEM) micrographs of the $\mathrm{Fe}-\mathrm{Mn}-\mathrm{Al}-\mathrm{Si}-\mathrm{C}$ and IF steels, after the polarization experiments in three different environments, are shown in Figure 11, Figure 12, Figure 13 [107]. In chloride solution, the $\mathrm{Fe}-\mathrm{Mn}-\mathrm{Al}-\mathrm{Si}-\mathrm{C}$ steel showed no localized corrosion (see Figure 11a), however uniform corrosion was observed. Contrarily, IF steel showed pitting corrosion in addition to the uniform corrosion (see Figure 11b). Both the steels showed extensive localized corrosion in acidic solution (see Figure 12). $\mathrm{Fe}-\mathrm{Mn}-\mathrm{Al}-\mathrm{Si}-\mathrm{C}$ steel was found to have increased corrosion compared to IF steel. A pit like morphology and some mud cracking adjacent to the region of localized attack region can be seen in the higher magnification micrograph of $\mathrm{Fe}-\mathrm{Mn}-\mathrm{Al}-\mathrm{Si}-\mathrm{C}$ steel tested in acidic solution, see Figure 12b. Pitting corrosion, however, was limited to a few small pits in the case of IF steel (see Figure 12c). $\mathrm{Fe}-\mathrm{Mn}-\mathrm{Al}-\mathrm{Si}-\mathrm{C}$ steel showed only a few sites of localized attack (see Figure 13a) in alkaline solution, however IF steel showed no noticeable corrosion attack (see Figure 13b). 

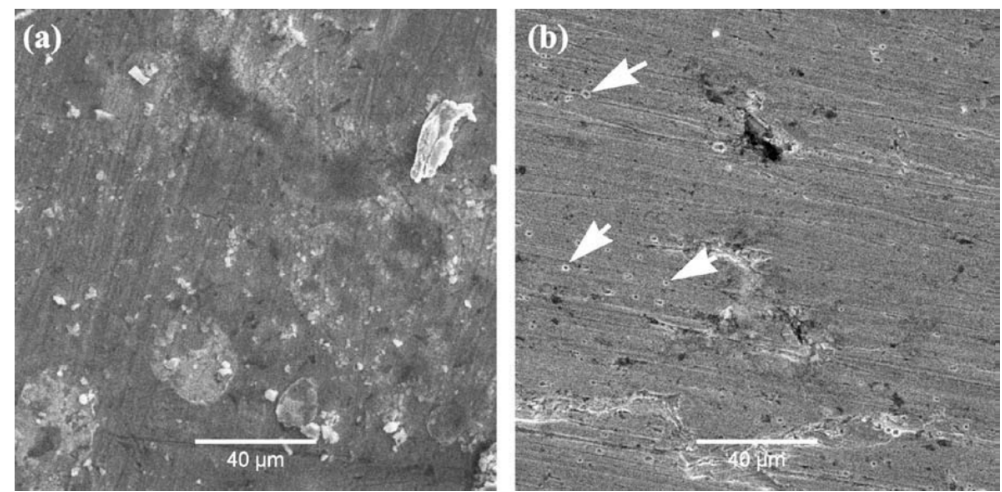

Figure 11. SEM micrographs for (a) Fe-Mn-Al-Si, and (b) interstitial-free (IF) steel after polarization experiments in $3.5 \mathrm{wt}$ \% $\mathrm{NaCl}$ [108]. (Reproduced with permission from refs. [108]. Copyright (2008), Elsevier).
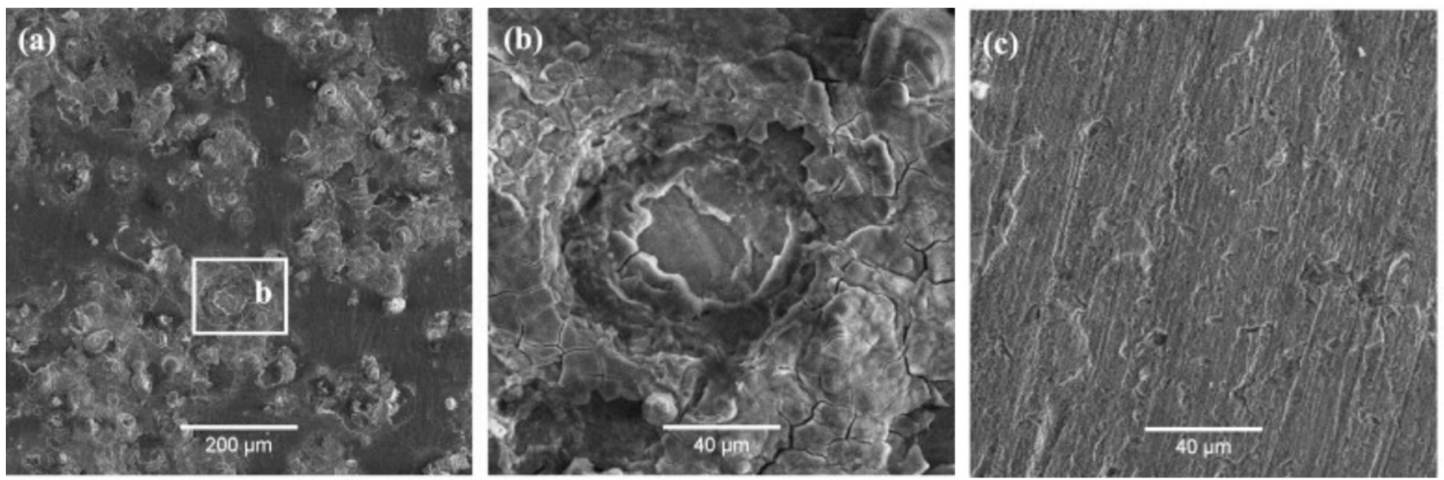

Figure 12. SEM micrographs for (a) and (b) Fe-Mn-Al-Si, and (c) interstitial-free (IF) steel after polarization experiments in $0.1 \mathrm{M} \mathrm{NaOH}$ [108]. (Reproduced with permission from refs. [108]. Copyright (2008), Elsevier).
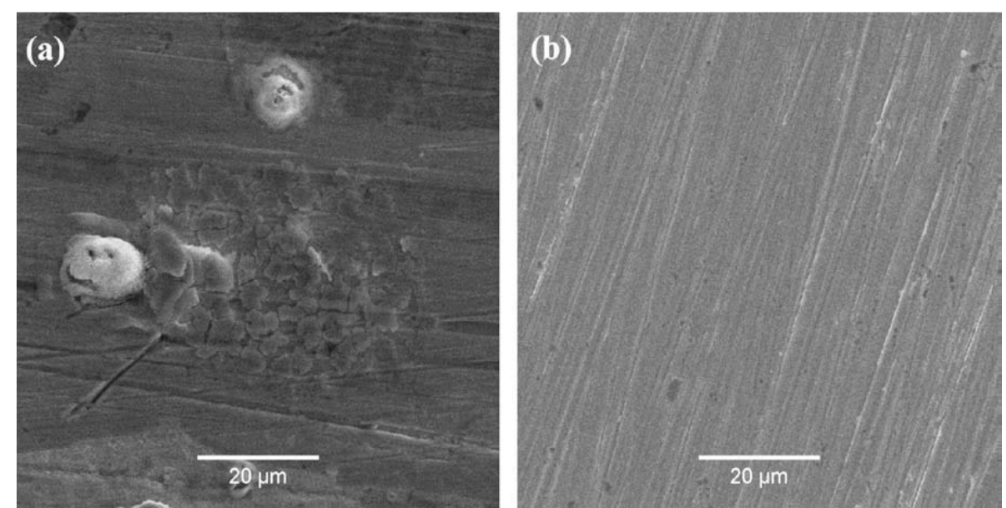

Figure 13. SEM micrographs for (a) Fe-Mn-Al-Si, and (b) interstitial-free (IF) steel after polarization experiments in $0.1 \mathrm{M} \mathrm{H}_{2} \mathrm{SO}_{4}$ [108]. (Reproduced with permission from refs. [108]. Copyright (2008), Elsevier).

\subsection{Effect of $\mathrm{Al}, \mathrm{Cu}$ and P Alloying on high-Mn TWIP Steel Corrosion}

Dieudonné et al. studied the corrosion behavior of four TWIP steel alloys $\mathrm{Fe}-18 \mathrm{Mn}-$ $0.6 \mathrm{C}-0.2 \mathrm{Si}-0.2 \mathrm{~V}-0.032 \mathrm{P}(\mathrm{REF}) ; \mathrm{Fe}-18 \mathrm{Mn}-0.6 \mathrm{C}-0.2 \mathrm{Si}-0.2 \mathrm{~V}-1.7 \mathrm{Cu}-0.031 \mathrm{P}(\mathrm{CU})$; $\mathrm{Fe}-17 \mathrm{Mn}-1.5 \mathrm{Al}-0.6 \mathrm{C}-0.2 \mathrm{Si}-0.2 \mathrm{~V}-0.005 \mathrm{P}$ (AL-low P); and also $\mathrm{Fe}-17 \mathrm{Mn}-1.5 \mathrm{Al}-0.6 \mathrm{C}-$ $0.2 \mathrm{Si}-0.2 \mathrm{~V}-0.037 \mathrm{P}(\mathrm{AL})$ in a $5 \mathrm{wt} . \% \mathrm{NaCl}$ (neutral $\mathrm{pH}$ ) using weight loss measurements, in a $5 \% \mathrm{Na}_{2} \mathrm{SO}_{4}$ solution ( $\mathrm{pH} \mathrm{1,4}$ and 6) using polarization experiments [98,114]. Weight loss for REF, CU, AL, and AL-low P specimens can be seen in Figure 14, the average corrosion rate was $\sim 0.2 \mathrm{~mm}_{\text {year }}{ }^{-1}$ for the REF and CU specimens and $\sim 0.1 \mathrm{~mm}$ year ${ }^{-1}$ for both 
the AL and AL-low P specimens [98]. Therefore, $\mathrm{Cu}$ alloying has no significant effect on the overall corrosion resistance, however the addition of $\mathrm{Al}$ produces a lower corrosion rate. This increased corrosion resistance is attributed to the formation of an $\mathrm{Al}$ rich passive layer. Using Faraday's law, the corrosion rates $\left(v_{\text {corr }}\right)$ of the four TWIP steel alloys were

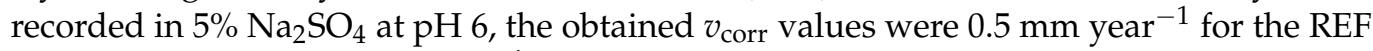
and AL-low P, and $0.4 \mathrm{~mm}$ year $^{-1}$ for CU and AL. Thus, the addition of alloying elements did not produce a significant difference on the initial $v_{\text {corr }}$. Furthermore, the addition of $\mathrm{P}$ in the AL specimen produced a lower $v_{\text {corr }}$, possibly due to a drop in surface reactivity during the initial stage of passivation, thus making the oxide layer less passive. The link between corrosion rates and hydrogen absorption by secondary ion mass spectrometry (SIMS) results in $5 \% \mathrm{Na}_{2} \mathrm{SO}_{4}$ solution at $\mathrm{pH} 4$, as shown in Figure 15 . Therefore, the $\mathrm{P}$ impurities in the AL sample increase the hydrogen adsorption. $\mathrm{Cu}$ does not affect the corrosion rates of the specimen; however, $\mathrm{Cu}$ enrichment of the oxide layer promote hydrogen recombination and decreases hydrogen adsorption. An improved corrosion resistance has been reported when alloying with $\mathrm{Al}$, due to decreased hydrogen absorption, therefore minimizing hydrogen embrittlement (HE) [98]. Consequently, the addition of minor alloying elements such as $\mathrm{Al}$ and $\mathrm{Cu}$ may help improve resistance of $\mathrm{Fe}-\mathrm{Mn}-\mathrm{C}$ steels to HE and stress corrosion cracking (SCC).

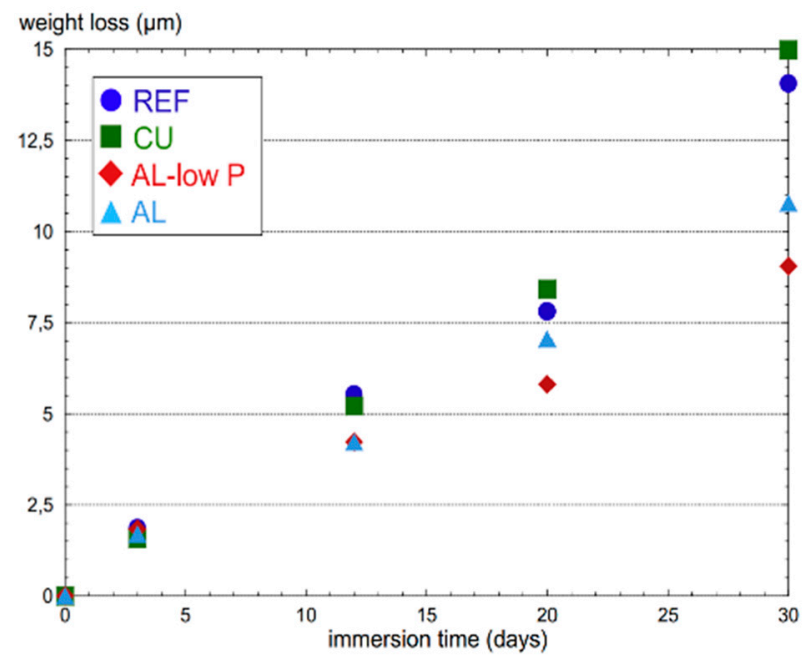

Figure 14. Weight loss versus time for Fe-18Mn-0.6C-0.032P exposed to 5 wt.\% $\mathrm{NaCl}$ [98]. (Reproduced with permission from refs. [98]. Copyright (2014), Elsevier).

\subsection{Effect of $\mathrm{Cr}, \mathrm{Cu}$, Si and N Alloying on High-Mn TWIP Steel Corrosion}

Múgica-Roncery et al. reported results on the corrosion resistance of the $\mathrm{Fe}-22 \mathrm{Mn}-0.6 \mathrm{C}$ and $\mathrm{Fe}-25 \mathrm{Mn}-3 \mathrm{Al}-3 \mathrm{Si}$ alloys in $0.5 \mathrm{M} \mathrm{H}_{2} \mathrm{SO}_{4}$. Manganese was incorporated to provide the plasticity effect. Various works regarding $\mathrm{Fe}-\mathrm{Mn}-\mathrm{Al}$ and $\mathrm{Fe}-\mathrm{Mn}-\mathrm{Al}-\mathrm{Si}$ systems in several environments show that the steel exhibits poor corrosion performance in saline and acidic environments compared to $\mathrm{Fe}-\mathrm{Cr}-\mathrm{Ni}$ SSs and IF-type steels [50]. $\mathrm{Fe}-18 \mathrm{Mn}-18 \mathrm{Cr}-\mathrm{C}-\mathrm{N}$ steel shows improved corrosion resistance compared to high-Mn Hadfield steel in a saline solution as shown in Figure 16 [115]. All the studied alloys, the reference $\mathrm{Fe}-24 \mathrm{Mn}-0.003 \mathrm{Al}-0.3 \mathrm{Si}-0.5 \mathrm{C}$ and the developed $\mathrm{Fe}-(20-30) \mathrm{Mn}-12 \mathrm{Cr}-$ $(0.24-0.3) \mathrm{C}-(0.32-0.4) \mathrm{N}$ steels showed a $\mathrm{C} / \mathrm{N}$ ratio of 0.75 in $0.5 \mathrm{M} \mathrm{H}_{2} \mathrm{SO}_{4}$ solution at room temperature. The active region of the steels was defined in the range of $-300 \mathrm{mV}$ to $0 \mathrm{mV}$ vs. SCE, followed by a passive region with $i_{\text {corr }}$ between $1-20 \mu \mathrm{A} \mathrm{cm}^{-2}$ associated with the $\mathrm{Cr}$-rich layers, and lastly, a transpassive region was defined. Compared to the reference steel, the developed samples exhibited more passive $i_{\text {corr }}$ values and smaller active areas. 

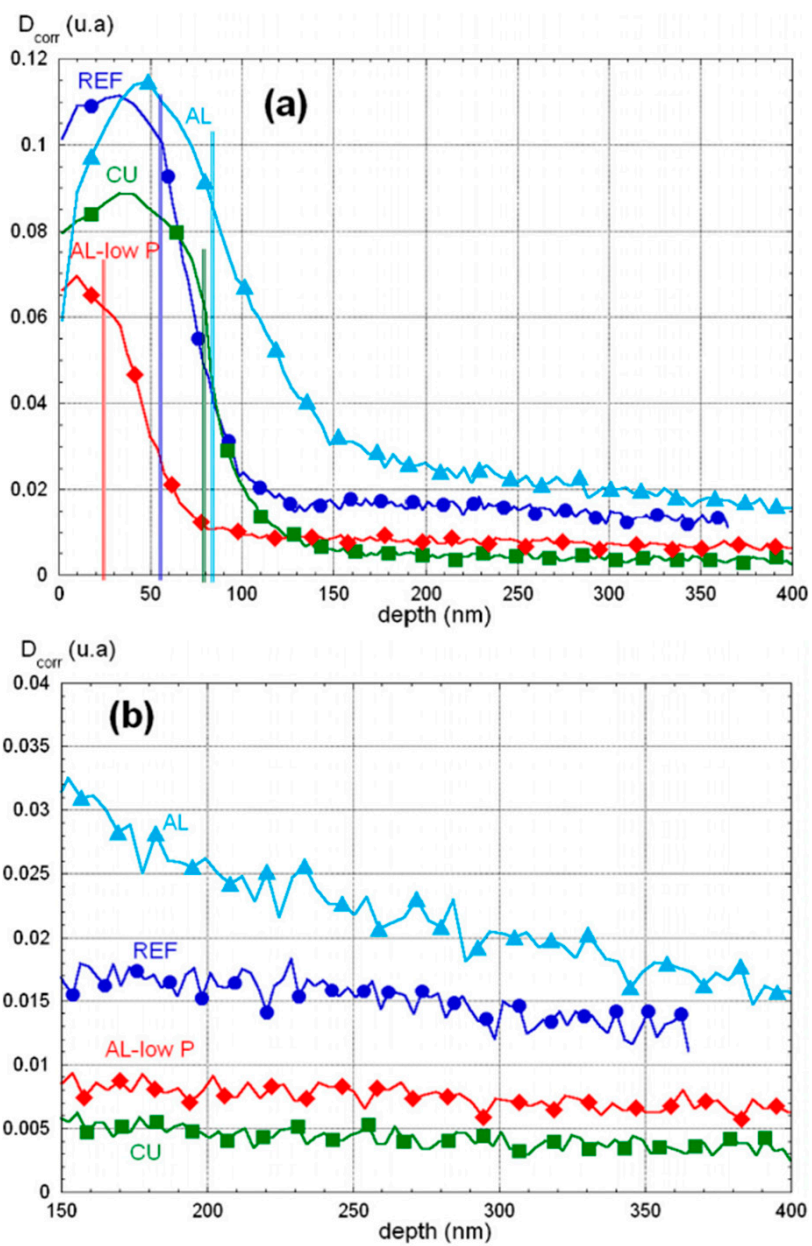

Figure 15. Secondary ion mass spectrometry (SIMS) profiling of deuterium ( $\left.\mathrm{D}_{\text {corr }}\right)$ in austenitic Fe-Mn-C TWIP steels exposed for $24 \mathrm{~h}$ at $25^{\circ} \mathrm{C}$ to a $5 \mathrm{wt}$. $\% \mathrm{Na}_{2} \mathrm{SO}_{4}$ deuterated solution at a $\mathrm{pH}$ of 4 . (a) Influence of alloying elements on the deuterium profile (vertical lines represent the oxide/metal interface), and (b) zoom of the deuterium profiles in the matrix [98]. (Reproduced with permission from refs. [98]. Copyright (2014), Elsevier).

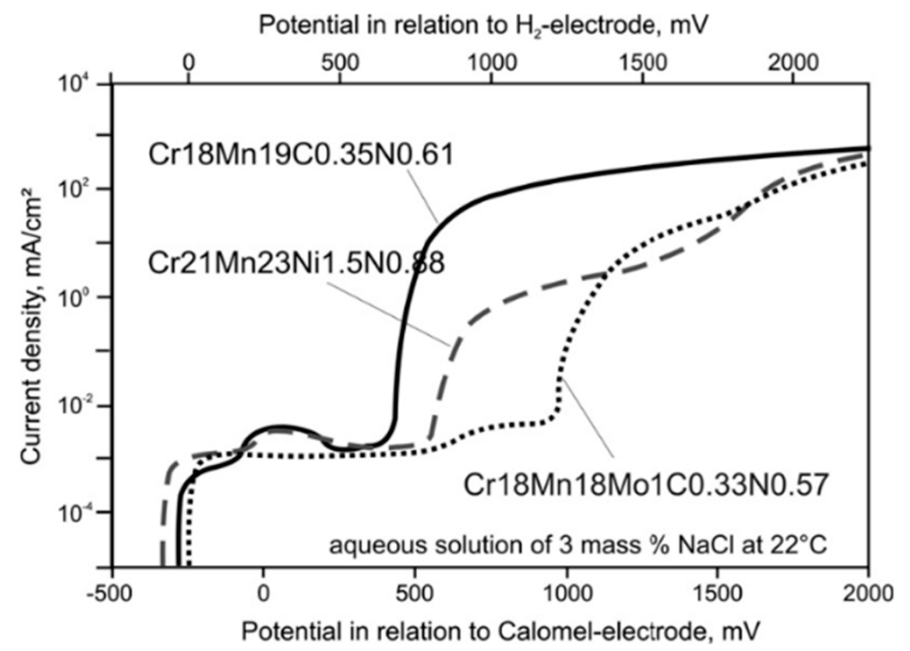

Figure 16. Potentiodynamic curves of steels Cr18Mn19C0.35N0.61, Cr18Mn18Mo1C0.33N0.57, and Cr21Mn23Ni1.5N0.88 [115]. (Reproduced with permission from refs. [115]. Copyright (2008), Elsevier). 
The corrosion resistance of $\mathrm{Fe}-25 \mathrm{Mn}-12 \mathrm{Cr}-0.3 \mathrm{C}-0.4 \mathrm{~N}$ in $0.5 \mathrm{M} \mathrm{H}_{2} \mathrm{SO}_{4}$ was compared to conventional TWIP steels, including $\mathrm{Fe}-25 \mathrm{Mn}-3 \mathrm{Al}-3 \mathrm{Si}$ and $\mathrm{Fe}-22 \mathrm{Mn}-0.6 \mathrm{C}$ [89]. It should be said that previous studies have been performed on $\mathrm{Fe}-\mathrm{Mn}-\mathrm{Al}-\mathrm{Si}$ [108], showing poor corrosion resistance in acidic $0.1 \mathrm{M} \mathrm{H}_{2} \mathrm{SO}_{4}$ solution due to the inability of $\mathrm{Al}$ to passivate, according to the Pourbaix diagram [116]. The $\mathrm{Fe}-25 \mathrm{Mn}-12 \mathrm{Cr}-0.3 \mathrm{C}-0.4 \mathrm{~N}$ steel showed superior corrosion behavior compared to the $\mathrm{Fe}-\mathrm{Mn}-\mathrm{C}$ reference steel in $0.5 \mathrm{M} \mathrm{H}_{2} \mathrm{SO}_{4}$ solution. The significant difference between the reference steel and the $\mathrm{Fe}-25 \mathrm{Mn}-12 \mathrm{Cr}-0.3 \mathrm{C}-0.4 \mathrm{~N}$ steel is the ability for $\mathrm{Cr}$ to build passive layers. $\mathrm{Fe}-25 \mathrm{Mn}-$ $12 \mathrm{Cr}-0.3 \mathrm{C}-0.4 \mathrm{~N}$ steel shows an active region from $-250 \mathrm{mV}$ to $+125 \mathrm{mV}$ vs. SCE and has a critical $i_{\text {corr }}$ of $72 \times 10^{3} \mu \mathrm{A} \mathrm{cm}^{-2}$ and the passive region reaches $1250 \mathrm{mV}$ vs. SCE, in which the $i_{\text {pass }}$ is $5 \mu \mathrm{A} \mathrm{cm}^{-2}$ and the first breakdown potential can be observed. Subsequently, a second passive region can be observed between 1125 to $1375 \mathrm{mV}$ vs. SCE. In contrast, the reference TWIP steel exhibits a significantly larger active region with higher current density values compared to the $\mathrm{Fe}-25 \mathrm{Mn}-12 \mathrm{Cr}-0.3 \mathrm{C}-0.4 \mathrm{~N}$ steel.

As a brief summary of the corrosion effect of the different elements, Al promotes passivity via the formation of a passive layer of $\mathrm{Al}_{2} \mathrm{O}_{3}$ film. This passivity ability is higher than the one promoted by $\mathrm{Cr}, \mathrm{Mn}$, or Fe [61,82]. Similarly, lower contents of $\mathrm{Cr}$ enhance passivity. However, higher contents (i.e., 6-9 wt.\%) are detrimental [117]. This is due to the $\mathrm{Cr}$ causing phase-segregations, generating nucleation points for pitting corrosion [85]. Regarding $\mathrm{Si}$, the formation of intermetallics such as $\mathrm{Fe}_{3} \mathrm{Al}$-Si impart passivity. Furthermore, an increase in the $E_{\text {pit }}$ and an extension of the passive region is observed [84,118]. Molybdenum affects the polarity of the passive film via formation of molybdates as well as a creation a bipolar interface that promotes repassivation via deactivation of pits growth [119]. Furthermore, Mo enhances the corrosion resistance forming a $\mathrm{MoO}_{3}$ oxide layer that converts to $\mathrm{MoO}_{4}{ }^{2-}$ in the interface. This limits the flux of $\mathrm{OH}^{-}$and $\mathrm{Cl}^{-}$ions into the surface [119].

\section{Effect of Mechanical Deformation on Corrosion of High-Mn TWIP Steels}

The corrosion behavior of steels may be altered by cold-working due to the increase in internal energy, thus increasing the corrosion rate [120]. As well, the passivation of conventional SS has also shown to be affected by cold-working [121], high-N SS display a high defect density in the alloy matrix, thus decreasing passivity in $3.5 \mathrm{wt} . \% \mathrm{NaCl}$ solution [122]. Moreover, 20\% cold-working has been shown to enhance the pitting resistance of austenitic SS containing N, however further deformation is detrimental to the passivity of the alloy, this behavior is attributed to the structural changes and deformations caused by cold-working [123].

Grajcar studied the corrosion behavior of $\mathrm{Fe}-26 \mathrm{Mn}-3 \mathrm{Al}-3 \mathrm{Si}-\mathrm{Nb}$ and $\mathrm{Fe}-25 \mathrm{Mn}-$ 1.5 Al-3Si- $\mathrm{Nb}-\mathrm{Ti}$ alloy sheets after a thermo-mechanical rolling process: (a) Heating at $1100{ }^{\circ} \mathrm{C}$ and austenitizing for $15 \mathrm{~min}$, (b) rolling from $1050{ }^{\circ} \mathrm{C}$ to $850{ }^{\circ} \mathrm{C}$ in 3 passes (20, 15 and 15\% reduction), (c) holding of the rolled sheet at the temperature of finishing for $15 \mathrm{~s}$, and (d) solution heat treatment of the specimens in water [124]. Immersion tests in $0.5 \mathrm{M} \mathrm{H}_{2} \mathrm{SO}_{4}$ solution for $100 \mathrm{~h}$ revealed $38 \%$ and $41 \%$ weight loss for $3 \mathrm{Al}$ and $1.5 \mathrm{Al}$ alloys, respectively, while in $3.5 \mathrm{wt} \% \mathrm{NaCl}$ solution, lower weight loss was observed of $0.4 \%$ and $0.5 \%$, for $3 \mathrm{Al}$ and $1.5 \mathrm{Al}$ alloys, respectively. The observed differences in weight loss were attributed to the presence of a small fraction of $\varepsilon$-martensite that has little effect on the corrosion process. Pitting was observed for both alloys, greater amounts of pitting was found in areas containing non-metallic inclusions. Hydrogen failures were observed to a depth of $0.3 \mathrm{~mm}$. The $i_{\text {corr }}$ in $0.5 \mathrm{M} \mathrm{H}_{2} \mathrm{SO}_{4}$ was measured to be $\sim 3400 \mu \mathrm{A} \mathrm{cm}^{-2}$, over 2 orders of magnitude higher than the $i_{\text {corr }}$ measured in 3.5 wt. $\% \mathrm{NaCl}$ solution $\left(\sim 8 \mu \mathrm{A} \mathrm{cm}^{-2}\right)$. A similar corrosion rate was observed for $\mathrm{Fe}-29 \mathrm{Mn}-3.1 \mathrm{Al}-1.4 \mathrm{Si}-0.05 \mathrm{C}$ steel [108]. The difference in the corrosion performance may be caused by the cathodic reaction, hydrogen ions are reduced to hydrogen gas in acidic $0.5 \mathrm{M} \mathrm{H}_{2} \mathrm{SO}_{4}$, while in the neutral 3.5 wt.\% $\mathrm{NaCl}$ environment, the cathodic reaction is the reduction of oxygen to hydroxide ions. The corrosion products formed were related to the chemical composition of the alloy rather 
than the phase structure, confirmed by the increased corrosion in the $1.5 \mathrm{Al}$ specimen due to its low $\mathrm{Al}$ concentration.

The study of corrosion properties of TMP TWIP steel in $3.5 \mathrm{wt} . \% \mathrm{NaCl}$ was examined by Wang et al. [125], the TMP was found to enhance the corrosion properties by measurements of $E_{\text {corr }}$, which increased from $-0.92 \mathrm{~V}$ to $-0.69 \mathrm{~V}$, and $i_{\text {corr }}$, which decreased from $8.76 \times 10^{-5} \mathrm{~A} \mathrm{~cm}^{-2}$ to $1.92 \times 10^{-5} \mathrm{~A} \mathrm{~cm}^{-2}$.

The existence of the second phases after heat treatment (ferrite, $\alpha^{\prime}$ - and $\varepsilon$-martensite) or as a result of plastic deformation during cold-straining (strain induced $\alpha^{\prime}$ - or $\varepsilon$-martensite) increases the $i_{\text {corr }}$ [126]. A galvanic couple is formed by the different phases with an austenite matrix; therefore, the corrosion rate increases. The results suggest that cold deformation of steel $(\mathrm{Fe}-26 \mathrm{Mn}-3 \mathrm{Al}-3 \mathrm{Si})$ has a significant effect on the $i_{\text {corr }}\left(3.7 \mathrm{~mA} \mathrm{~cm}^{-2}\right)$ in $0.1 \mathrm{M}$ $\mathrm{H}_{2} \mathrm{SO}_{4}$. Compared to TMP specimens $\left(1.7 \mathrm{~mA} \mathrm{~cm}{ }^{-2}\right)$, cold-deformed $\mathrm{Fe}-26 \mathrm{Mn}-3 \mathrm{Al}-3 \mathrm{Si}$ steel specimens show lower corrosion resistance. Cold-deformed steel showed greater amounts of corrosion pits than the TMP steel. This can be attributed to the increased dislocation density and twins after cold-working, see Figure 17. The grain boundaries show a particular susceptibility to pit nucleation [126]. The current density values measured for cold-strained $26 \mathrm{Mn}-2.9 \mathrm{Al}-3 \mathrm{Si}$ steel were notably less than that of hot-rolled steel containing a lower $\mathrm{Al}$ content $(\mathrm{Fe}-27 \mathrm{Mn}-1.7 \mathrm{Al}-4 \mathrm{Si})$. Consequently, the effect of cold working is less significant than the combined effects offered by the decreased $\mathrm{Al}$ addition and the increased Si content in the $\mathrm{Fe}-27 \mathrm{Mn}-1.7 \mathrm{Al}-4 \mathrm{Si}$ steel. Therefore, the corrosion resistance of high-Mn steels shows greater dependency on chemical composition than the effects of cold-work deformation. Increasing $\mathrm{Al}$ additions from 1.7\% to approximately $2.9 \%$ produces a noticeable advantage in corrosion behavior.

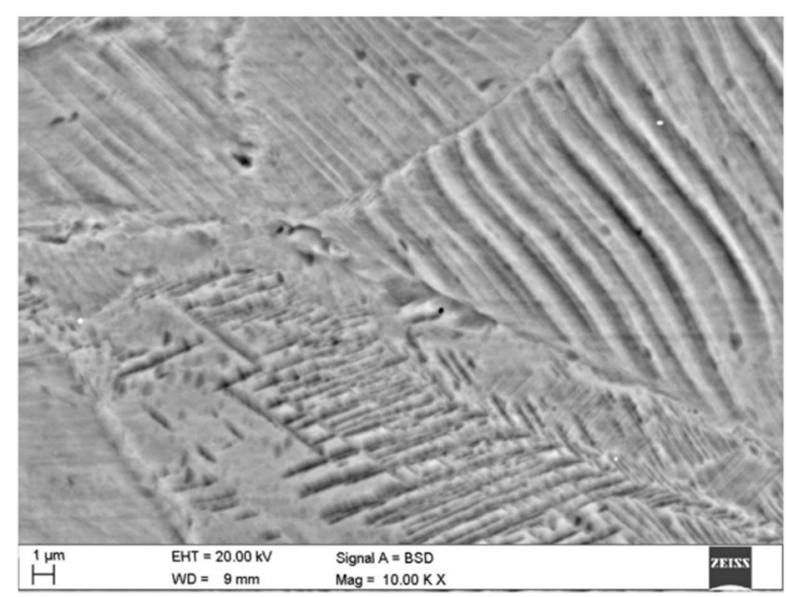

Figure 17. SEM image of the austenitic microstructure of $16 \mathrm{Mn}-3 \mathrm{Si}-3 \mathrm{Al}$ cold-worked TWIP steel showing slip bands and deformation twins [126].

The corrosion behavior changes of $\mathrm{Fe}-29 \mathrm{Mn}-3.5 \mathrm{Al}-0.5 \mathrm{Si}-0.5 \mathrm{C}$ steel in $3.5 \mathrm{wt} . \%$ $\mathrm{NaCl}$ solution induced by cold-plastic deformation was studied by Ghayad et al. [127]. Using potentiodynamic testing, no tendency for passivation was detected, thus it is independent of the steel structure after heat treatment (supersaturated aged or strain-aged). Annealing causes faster steel dissolution, thus the deformed specimens exhibit a higher corrosion rate than the supersaturated specimens and have a different potential than the matrix. The strain-aged samples display the highest corrosion rate due to the galvanic cell created by the coupling of ferrite with the austenite matrix [124].

The corrosion properties of $\mathrm{Fe}-29 \mathrm{Mn}-3 \mathrm{Al}-1.6 \mathrm{Si}-0.06 \mathrm{C}$ TWIP steel cold-worked to $0 \%, 20 \%$, and $35 \%$ were studied in $0.1 \mathrm{M} \mathrm{H}_{2} \mathrm{SO}_{4}, 0.1 \mathrm{M} \mathrm{NaOH}$, and 3.5 wt. $\% \mathrm{NaCl}$ [120]. The $E_{\text {corr }}$ values for the $20 \%$ cold-worked specimen in $3.5 \mathrm{wt} . \% \mathrm{NaCl}$ presented more noble values compared to the non-deformed steel. Nevertheless, cold-work deformation of $35 \%$ shifted the $E_{\text {corr }}$ closer to the non-deformed specimen. The $i_{\text {corr }}$ measured for $20 \%$ cold-work deformation $\left(18 \mu \mathrm{A} \mathrm{cm}{ }^{-2}\right)$ was lower and less active than the $i_{\text {corr }}$ measured 
for the non-deformed specimen $\left(23 \mu \mathrm{A} \mathrm{cm}{ }^{-2}\right)$, howeve when cold-work is increased to $35 \%, i_{\text {corr }}$ increased to $21 \mu \mathrm{A} \mathrm{cm}^{-2}$. For the $0.1 \mathrm{M} \mathrm{NaOH}$ environment, the $E_{\text {corr }}$ of $20 \%$ cold-worked specimen showed a similar value to that of the non-deformed specimen, although $35 \%$ cold-work showed a shift towards more noble values. The $20 \%$ specimen $i_{\text {corr }}$ was $2 \mu \mathrm{A} \mathrm{cm}^{-2}$ as well as the non-deformed steel, however the $35 \%$ cold-worked specimen had an $i_{\text {corr }}$ of $3 \mu \mathrm{A} \mathrm{cm}{ }^{-2}$. The $E_{\text {corr }}$ and $i_{\text {corr }}$ values for $0.1 \mathrm{M} \mathrm{H}_{2} \mathrm{SO}_{4}$ solution were similar to those observed in $3.5 \mathrm{wt} . \% \mathrm{NaCl}$ solution. For the $20 \%$ cold-worked, nondeformed, and 35\% cold-worked specimens, the $i_{\text {corr }}$ was $1513 \mu \mathrm{A} \mathrm{cm}{ }^{-2}, 2237 \mu \mathrm{A} \mathrm{cm}^{-2}$ and $1729 \mu \mathrm{A} \mathrm{cm}^{-2}$, respectively. The difference in corrosion performance was attributed to the $\mathrm{Si}$, which forms a silica film in acidic solution, therefore the passive film formation is impeded by high dissolution of Fe and $\mathrm{Mn}[69,90]$. In chloride solutions near neutral $\mathrm{pH}$, $\mathrm{Al}$ forms a protective $\mathrm{Al}$ oxide passive film, while alkaline $\mathrm{pH}$ experiences high corrosion resistance due to the passivating properties of Fe and Mn.

Fu et al. studied the effect cold-rolling and/or sensitization on the corrosion properties of nickel-free high-N SS (HNSS), $\mathrm{Fe}-15.8 \mathrm{Mn}-18.4 \mathrm{Cr}-2.19 \mathrm{Mo}-0.66 \mathrm{~N}-0.24 \mathrm{Si}-0.04 \mathrm{C}$, in 3.5 wt. $\% \mathrm{NaCl}(\mathrm{pH} \sim 5.8), 0.5 \mathrm{M} \mathrm{H}_{2} \mathrm{SO}_{4}+0.5 \mathrm{M} \mathrm{NaCl}(\mathrm{pH} \sim 0.4)$, and $0.5 \mathrm{M} \mathrm{NaOH}+0.5 \mathrm{M}$ $\mathrm{NaCl}$ ( $\mathrm{pH} ~ 13.1)$ using polarization, EIS, XPS, SEM, and TEM results [122]. The cold rolling was conducted with thickness reductions of $8,30,49$, or $60 \%$ and the sensitization was performed at $650{ }^{\circ} \mathrm{C}$ for $2 \mathrm{~h}$. The Nyquist plots with fitting to an equivalent circuit are shown in Figure 18 [122,128,129]. Cold-working creates an increase defect density into the matrix, thus producing a less protective passive film and reduced corrosion resistance for HNSS with heavy cold-working (30 and 60\%) in a $3.5 \mathrm{wt} . \% \mathrm{NaCl}$ solution. The highly cold-worked HNSS developed a passive film with fewer oxides and greater amounts of hydroxides. Unsensitized HNSS displayed no decrease in corrosion resistance. The poor corrosion resistance properties were attributed to the loss of anti-corrosion elements in the passive film, such as Cr and Mo, supported by the XPS results. SEM images showed the precipitation of $\chi$-phase in the grain and at the grain boundaries; see Figure $19[122,130]$.
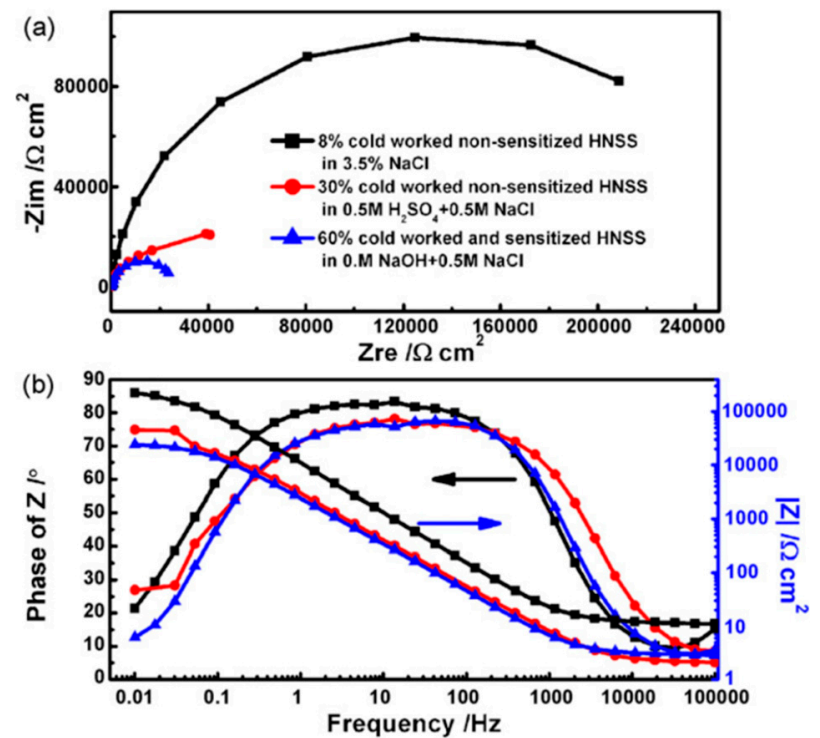

(c)

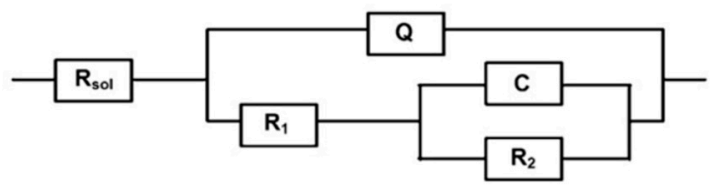

Figure 18. Fe-15Mn-18Cr-2Mo-0.7N-0.04C in 3.5 wt.\% NaCl: (a) Nyquist plot, (b) bode plot, and (c) electrical equivalent circuit used to fit impedance data [122]. (Reproduced with permission from refs. [122]. Copyright (2009), Elsevier). 

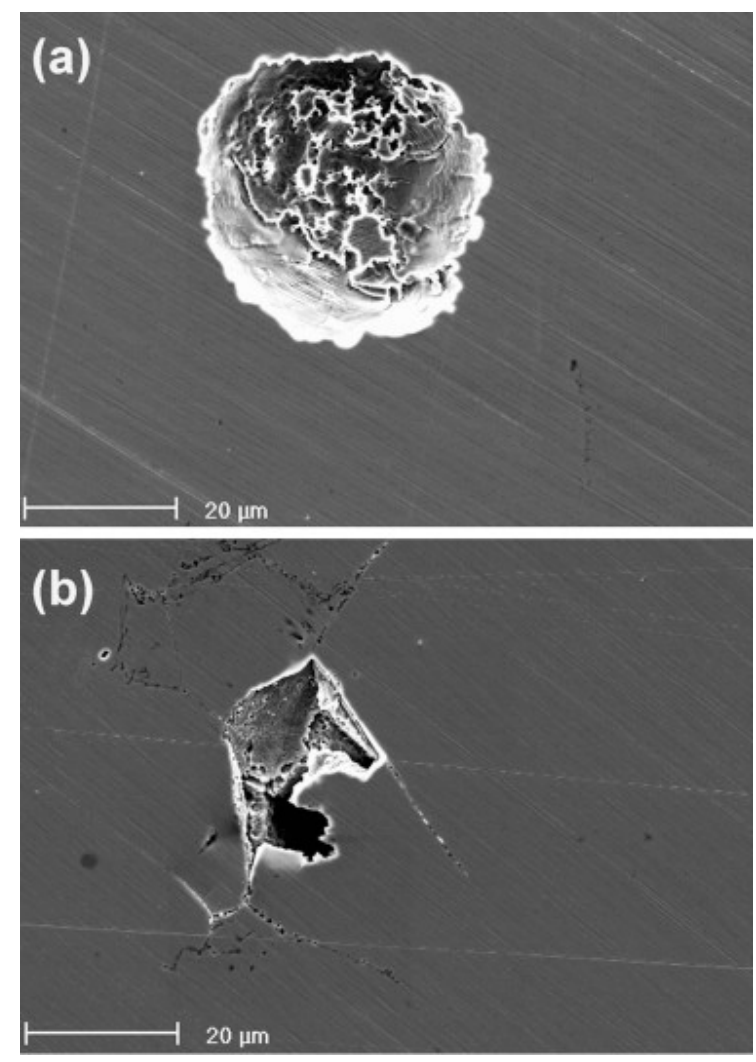

Figure 19. SEM micrographs showing surface pit in: (a) 49\% cold worked non-sensitized specimen, and (b) $49 \%$ cold worked and sensitized specimen after potentiodynamic polarization in a $3.5 \% \mathrm{NaCl}$ solution [122]. (Reproduced with permission from refs. [122]. Copyright (2009), Elsevier).

Studies of pitting corrosion were examined on cold-worked (thickness reduction of $5,10,15,20,30$, or $60 \%) \mathrm{N}$-bearing $(0.05,0.1$, and $0.22 \%)$ type austenitic AISI 316L SS, in neutral chloride solution ( $3.5 \mathrm{wt} . \% \mathrm{NaCl})$ [123]. A decrease in pitting corrosion was observed at up to $20 \%$ cold-working, while increasing to $30 \%$ and $40 \%$ cold-working caused a sudden decrease in pitting resistance. N promotes passivity, increasing the pitting corrosion resistance and improves stress corrosion cracking resistance [131]. For instance, the study performed by Kamachi Mudali et al. showed that increasing the content of $\mathrm{N}$ from $0.05 \%$ to $0.22 \%$ significantly increased the pitting corrosion resistance [123]. Regarding cold work, a relationship between pitting and cold work was identified. Setting the optimal cold work to $20 \%$ as higher values drastically affect pitting corrosion resistance [123].

Austenitic steels have been shown to improve the mechanical properties with the formation of nano/fine-grained structures [132,133]. The effect of TMP on the corrosion behavior of $\mathrm{Fe}-18 \mathrm{Mn}-2 \mathrm{Al}-2 \mathrm{Si}-0.07 \mathrm{C}$ steel in $3.5 \mathrm{wt} . \% \mathrm{NaCl}$ solution was studied by Yeganeh et al. [134]. The Bode plots showed higher $Z$-module $(|Z|)$ and phase-angle $(\theta)$ values for the fine-grained (FG) specimen compared to the coarse-grained (CG) specimen, corresponding to the higher resistance of the oxide or passive film. These findings were attributed to the lowest energy grain boundaries evaluated on the microstructure of FG specimen [135]. The Mott-Schottky plots for the FG and CG specimens showed a higher donor density $\left(N_{\mathrm{D}}\right)$ for FG specimen $\left(11 \times 10^{21} \mathrm{~cm}^{-3}\right)$ than for CG specimen $\left(9 \times 10^{21} \mathrm{~cm}^{-3}\right)$, which was attributed to higher quantities of grain boundary defects of the FG specimen, favoring the diffusion of oxygen atoms through the surface [134]. Similarly, a study performed by Bosch et al. showed a capacitive behavior consisting of two-time constants at high frequencies, attributed to the passive layer, and one at the low frequencies attributed to the corrosion phenomena, as shown in Figure 20 [88]. These results also showed how the high Mn content (30 wt.\%) severely affected the corrosion performance [88]. 

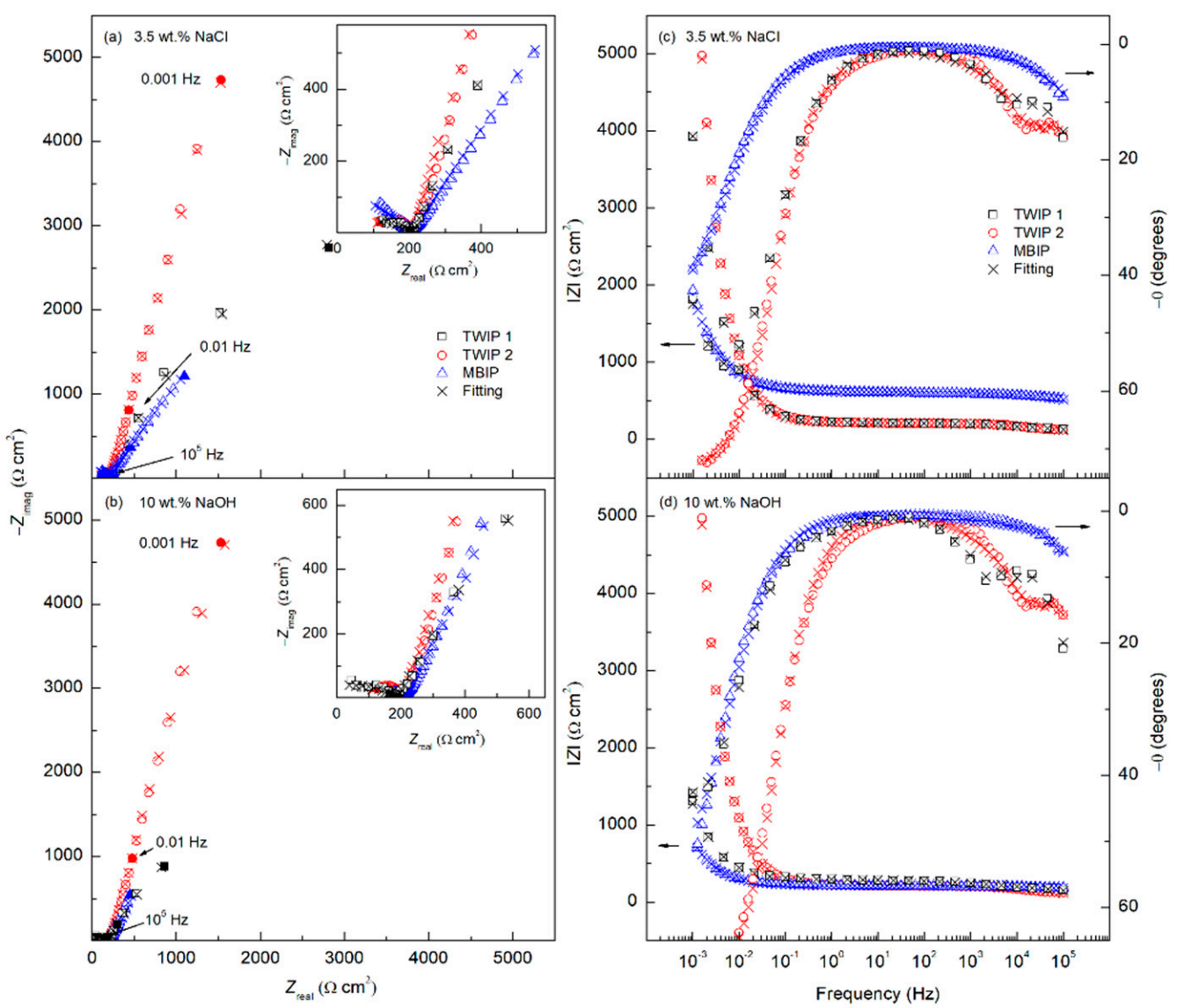

Figure 20. Nyquist plots of two TWIP steels $(\mathrm{Fe}-22.6 \mathrm{Mn}-6.3 \mathrm{Al}-3.1 \mathrm{Cr}-0.68 \mathrm{C}$ and $\mathrm{Fe}-28 \mathrm{Mn}-$ 5.2Al-5.1Cr-2.8Si-0.95C) and a MBIP steel (Fe-30Mn-8.5Al-3.2Cr-1.1Mo-1.0C) in: (a) $3.5 \mathrm{wt} . \%$ $\mathrm{NaCl}$ solution, and (b) $10 \mathrm{wt} . \% \mathrm{NaOH}$ solution. Corresponding bode plots in: (c) $3.5 \mathrm{wt} . \% \mathrm{NaCl}$ solution, and (d) 10 wt.\% $\mathrm{NaOH}$ solution [88].

As indicated above, recently the authors have studied the influence of $\mathrm{Cr}$ on the passivity of TMP Fe$-30 \mathrm{Mn}-5 \mathrm{Al}-(0,3,6,9) \mathrm{Cr}-0.5 \mathrm{C}$ TWIP steel in $0.1 \mathrm{M} \mathrm{NaCl}$ solution [85]. XPS results for $\mathrm{Fe}-30 \mathrm{Mn}-5 \mathrm{Al}-0.5 \mathrm{C}$ TWIP steel can be seen in Figure 21. The outer layer of the passive film experienced a gradual enrichment of $\mathrm{Cr}$. The TWIP steel $(\mathrm{Fe}-30 \mathrm{Mn}-5 \mathrm{Al}-0.5 \mathrm{C})$ passive film was determined to be composed primarily of $\mathrm{Fe}$ and $\mathrm{Al}$ oxides. Increased concentrations of oxidized $\mathrm{Cr}$ species were detected for all four TWIP steels tested, corroborating the electrochemical results. The CPP curves for the four TMP Fe-30Mn-5Al$(0,3,6,9) \mathrm{Cr}-0.5 \mathrm{C}$ TWIP steels are shown in Figure 22 for the reference TWIP steel specimen $(0 \mathrm{wt} . \% \mathrm{Cr})$ and the three developed steels $(3,6$, and $9 \mathrm{wt} . \% \mathrm{Cr})$, immersed in the deaerated $0.1 \mathrm{M} \mathrm{NaCl}$ solution at room temperature. Both the reference and developed TWIP alloy showed peaks corresponding to the oxidized Mn species [85]. 
(a)

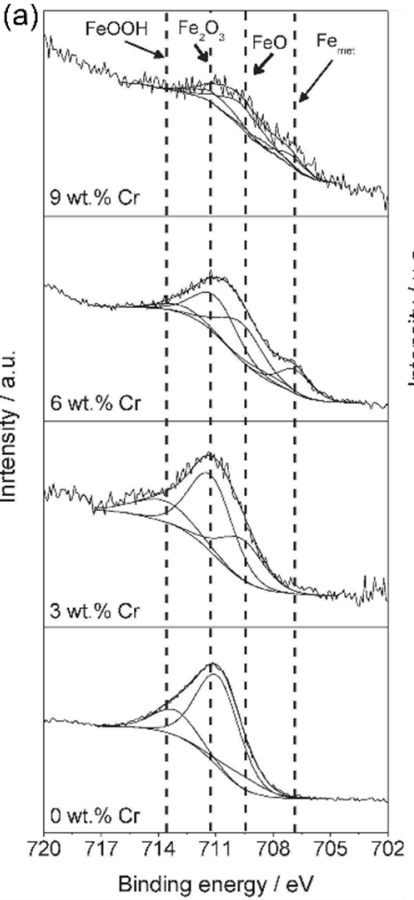

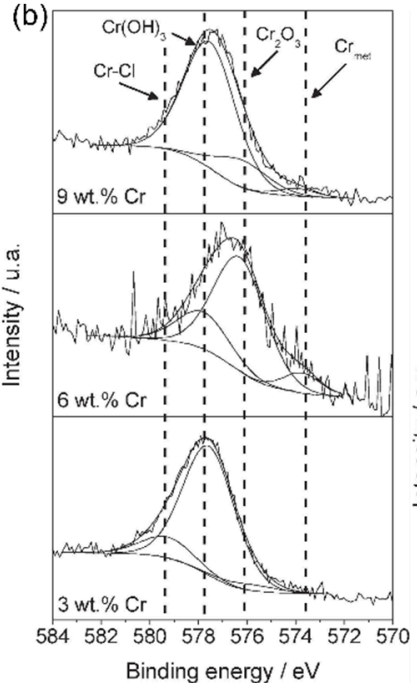

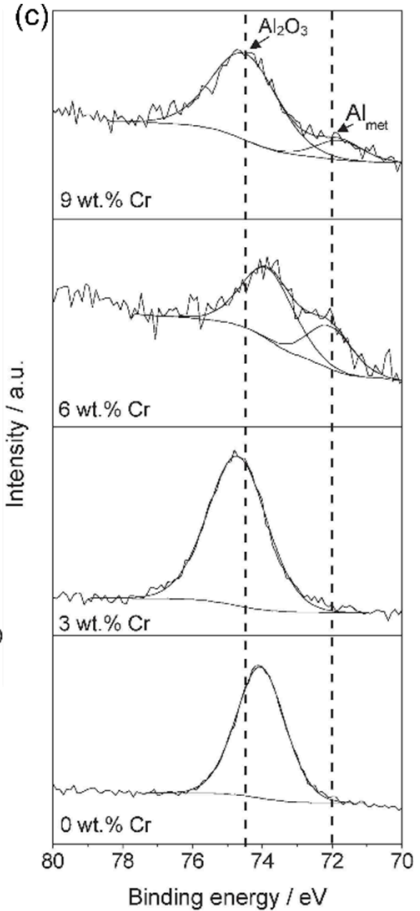

Figure 21. High-resolution XPS spectra for thermo-mechanical processed (TMP) Fe-30Mn-5Al$(0,3,6,9) \mathrm{Cr}-0.5 \mathrm{C}$ TWIP steels with $0,3,6$, and 9 wt. $\%$ Cr. (a) Fe $2 \mathrm{p}_{3 / 2}$, (b) $\mathrm{Cr} 2 \mathrm{p}_{3 / 2}$, and (c) $\mathrm{Al} 2 \mathrm{p}$ after exposure to deaerated $0.1 \mathrm{M} \mathrm{NaCl}$ solution [85]. (Reproduced with permission from refs. [85]. Copyright (2020), Elsevier).

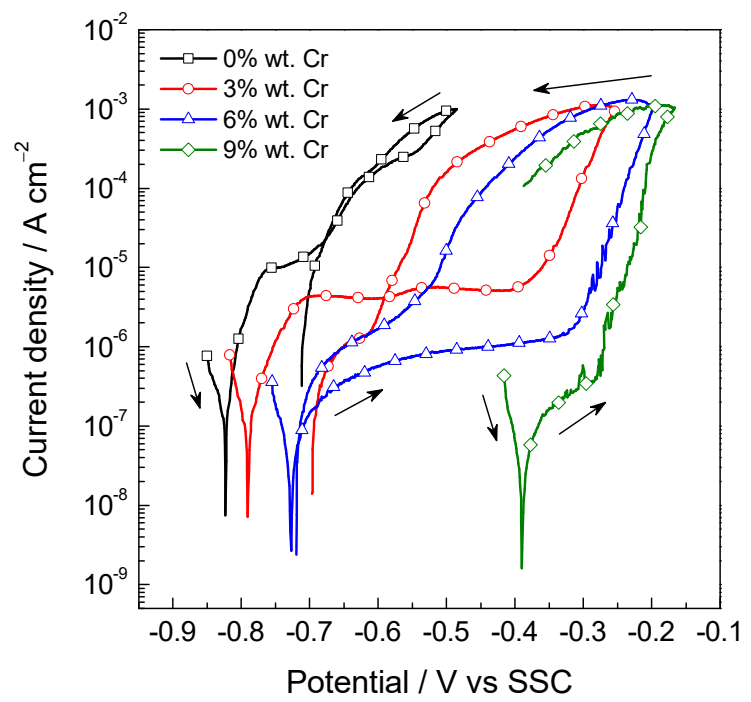

Figure 22. Cyclic polarization curves for thermo-mechanical processed (TMP) Fe-30Mn-5Al$(0,3,6,9) \mathrm{Cr}-0.5 \mathrm{C}$ TWIP steels with $0,3,6$, and $9 \mathrm{wt} . \% \mathrm{Cr}$ exposed to $0.1 \mathrm{M} \mathrm{NaCl}$ solution [85]. (Reproduced with permission from refs. [85]. Copyright (2020), Elsevier).

High-entropy DP Fe-30Mn-10Co-10Cr alloy (DP-HEA) was studied in $3.5 \mathrm{wt} . \%$ $\mathrm{NaCl}$ solution by Lu et al. [136], and a decreased $E_{\text {pit }}$ and narrower passive region than equiatomic $\mathrm{Co}-\mathrm{Cr}-\mathrm{Fe}-\mathrm{Mn}-\mathrm{Ni}$ (HEA) was observed. Higher $\mathrm{Mn}$ content and lower $\mathrm{Cr}$ and Fe content was detected for DP-HEA compared to HEA. Table 4 summarizes corrosion rate $\left(v_{\text {corr }}\right)\left(\mu\right.$ year $\left.^{-1}\right)$ values for high-Mn TWIP steel containing $\mathrm{Al}$ and Si elements. 
Table 4. Corrosion rate $\left(v_{\text {corr }}\right)\left(\mu \mathrm{m}_{\text {year }}{ }^{-1}\right)$ values for high-Mn TWIP steels with aluminum and silicon elements.

\begin{tabular}{|c|c|c|c|}
\hline Alloy & Electrolyte & $v_{\text {corr }} \mu \mathrm{m}$ year $^{-1}$ & Reference \\
\hline Fe-15Mn-3Al-3Si & $0.5 \mathrm{M} \mathrm{H}_{2} \mathrm{SO}_{4}$ & 127.6 & {$[50]$} \\
\hline Fe-29Mn-3.5Al-0.5Si-0.5C & $3.5 \% \mathrm{NaCl}$ & 30.5 & [127] \\
\hline Fe-29Mn-3.5Al-0.5Si-0.5C & $3.5 \% \mathrm{NaCl}$ & 147.2 & [127] \\
\hline Fe-30Mn-1Al-1Si-1C & $1 \mathrm{~N} \mathrm{H}_{2} \mathrm{SO}_{4}$ & $0.2 \times 10^{3}$ & {$[66]$} \\
\hline Fe-32.7Mn-6.59Al-1.26Si-0.25C & $1 \mathrm{~N} \mathrm{H}_{2} \mathrm{SO}_{4}$ & 98,493 & [109] \\
\hline Fe-32.7Mn-8.54Al-1.3Si-0.54C & $1 \mathrm{~N} \mathrm{H}_{2} \mathrm{SO}_{4}$ & $0.3 \times 10^{3}$ & [109] \\
\hline Fe-18Mn-2Al-2Si-0.07C & $3.5 \% \mathrm{NaCl}$ & 39.2 & [134] \\
\hline Fe-30Mn-3Al-1.5Si-0.06C & $3.5 \% \mathrm{NaCl}$ & 263 & [120] \\
\hline Fe-17.3Mn-3.10Al-0.38Si-0.24C & $3.5 \% \mathrm{NaCl}$ & 366 & [78] \\
\hline Fe-20.6Mn-3.5Al-2.92Si-0.29C & $3.5 \% \mathrm{NaCl}$ & 46.3 & [78] \\
\hline Fe-30Mn-3Al-1.5Si-0.06C & $0.1 \mathrm{M} \mathrm{NaOH}$ & 22.9 & [120] \\
\hline Fe-30Mn-3Al-1.5Si-0.06C & $0.1 \mathrm{M} \mathrm{H}_{2} \mathrm{SO}_{4}$ & 25,921 & [120] \\
\hline Fe-30Mn-10Al-1Si-1C & $3.5 \% \mathrm{NaCl}$ & 20 & {$[66]$} \\
\hline Fe-30.5Mn-7.5Al-1.5Si-1C & $3.5 \% \mathrm{NaCl}$ & 50 & [66] \\
\hline Fe-30.5Mn-7.5Al-1Si-1C & $3.5 \% \mathrm{NaCl}$ & 350 & {$[66]$} \\
\hline Fe-30.5Mn-7.5Al-0.5Si-1C & $3.5 \% \mathrm{NaCl}$ & 230 & {$[66]$} \\
\hline Fe-33Mn-9Al-1.4Si-0.9C & $3.5 \% \mathrm{NaCl}$ & $3.775 \times 10^{3}$ & [112] \\
\hline Fe-29Mn-8.6Al-2.7Si-0.7C & $3.5 \% \mathrm{NaCl}$ & $2.573 \times 10^{3}$ & [112] \\
\hline Fe-24Mn-7.3Al-2Si-1C & $3.5 \% \mathrm{NaCl}$ & $2.354 \times 10^{3}$ & [112] \\
\hline
\end{tabular}

\section{Stress Corrosion Cracking of High-Mn TWIP Steels}

High-Mn TWIP steels, while they provide high strength, ductility, and good corrosion properties, suffer from the combined effect of the tensile stress and corrosion, a phenomenon known as stress corrosion cracking (SCC), degrading the steel and leading to a premature failure. The SCC mechanism in high-Mn TWIP steels depends on several factors including: Outer surface microstructure, type of environment and applied potential and, elemental composition of the steel $[137,138]$.

The outermost surface of the TWIP steel plays an important role on the SCC behavior, the higher the grain refinement the higher the grain boundary density, increasing the sites for SCC initiation, as the grain boundaries behave as hydrogen trapping sites $[139,140]$. The percentage of strain-induced martensite and deformation twins also influence the SCC initiation, due to the higher susceptibility of martensite and deformation twins to suffer SCC than the austenitic microstructure. This difference can be seen in literature, where martensitic stainless steels subjected to SCC in $3.5 \mathrm{wt} . \% \mathrm{NaCl}$ at room temperature $\left(25^{\circ} \mathrm{C}\right)$ experience intergranular fracture with the formation of secondary cracks [141,142]; while austenitic stainless steels needed higher temperatures to develop SCC $\left(>100{ }^{\circ} \mathrm{C}\right)[137,143]$, lower $\mathrm{pH}(\mathrm{pH}<3)[144,145]$, or higher chloride content $(24.2 \mathrm{wt} . \% \mathrm{NaCl})$ in the case of exposure to alkaline solutions (sat. $\mathrm{CaCl}_{2}$ ) $[143,146]$.

The environment will also influence the SCC susceptibility as higher chloride contents will promote a faster crack initiation, and lower $\mathrm{pH}$ will promote faster hydrogen evolution reactions kinetics increasing the HE susceptibility. In addition to the environment, the applied potential may cause a premature hydrogen evolution for cathodic potentials, while more anodic dissolution is seen for anodic potentials [146]. Cathodic potentials have shown to increase the SCC susceptibility, where the dominant mechanism is the HE promoting a brittle fracture by transgranular SCC $[137,138,147,148]$. SCC mechanism of high-Mn austenitic Fe-29.7Mn-8.7 Al-1.04C steel was studied by Tjong in $20 \mathrm{wt} . \%$ $\mathrm{NaCl}$ solution at $100{ }^{\circ} \mathrm{C}$ using slow strain rates [142]. HE occurred at cathodic potentials induced by hydrogen adsorption and diffusion into the alloy during the slow strain rate test. Moreover, aging treatments lead to the decomposition of austenite into ferrite and $\beta$-Mn phases at the austenite grain boundaries [147]. The fracture surface of the alloy strained at $2.8 \times 10^{-7} \mathrm{~s}^{-1}$ is shown in Figure 23. The intergranular fracture can be observed. 
Furthermore, the crack propagation occurred through the $\beta-$ Mn phase and subsequently along the ferrite $-\beta-\mathrm{Mn}$ and austenite grain boundaries. However, the initiation was observed on the $\beta-$ Mn phase [147].

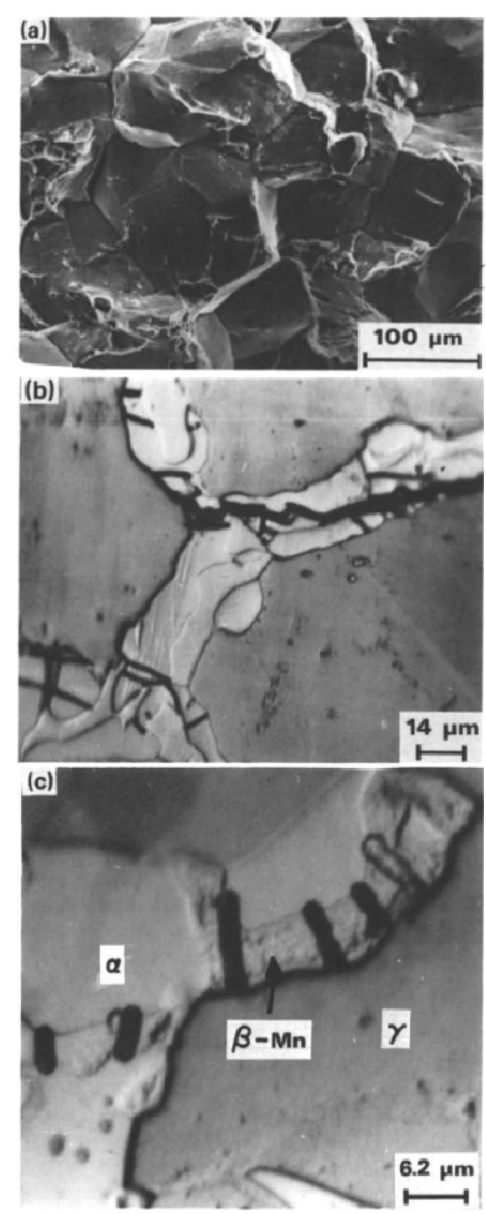

Figure 23. (a) SEM fractography of the $\mathrm{Fe}-8.7 \mathrm{~A} 1-29.7 \mathrm{Mn}-1.04 \mathrm{C}$ alloy (aged at $550{ }^{\circ} \mathrm{C}$ for $396 \mathrm{ks}$ ) after slow-rate straining in a $20 \% \mathrm{NaCl}$ solution $\left(100{ }^{\circ} \mathrm{C}\right)$ at the applied cathodic potential of $-0.800 \mathrm{~V}(\mathrm{Ag} / \mathrm{AgCl})$; (b) optical micrograph of the longitudinal cross section of this aged alloy, which failed at $-0.800 \mathrm{~V}(\mathrm{Ag} / \mathrm{AgCl})$; (c) a higher magnification of the SEM micrograph showing that the cracks originated from the $\beta-\mathrm{Mn}$ phase [147]. (Reproduced with permission from refs. [147]. Copyright (1986), Elsevier).

The elemental composition of high-Mn TWIP steels can induce a higher SCC susceptibility or a protection against it depending on the alloy elements and their ratios. Additions of $\mathrm{Cr}$ to Fe-Mn-Cr-N steel decreased the SCC susceptibility when subjected to artificial sea water environment [149]. From the study of Chang et al., the addition of Mo did not increase the SCC susceptibility, but it moved the HE potential towards more negative potential. However, the addition of Si did increase the SCC susceptibility even if it lowered the HE potential like in the Mo addition [146]. In addition, on the regard of element addition to high-Mn TWIP steels, $\mathrm{Al}$ has been of great interest for the scientific community. $\mathrm{Al}$ additions have shown to increase the stacking fault energy (SFE), accordingly reducing the deformation twinning and decreasing the probability of forming $\varepsilon$-martensite $[150,151]$. Other studies regarded the $\mathrm{Al}$ additions to reduce the effect of the HE in TWIP steels, which is very detrimental [152,153]. Increasing the Al content of TWIP steels decrease the HE effect by reducing the dynamic strain aging [154]; similarly, the Al addition to TWIP steels showed the decrease in shear modulus hence, decreasing the hydrogen charging and promoting less HE [151,155]. 


\section{Hydrogen Embrittlement of High-Mn TWIP Steels}

The phenomenon known as HE is a destructive process of hydrogen damage to the mechanical properties of a metal, which has been extensively studied in high-Mn TWIP steels [156-168]. The introduction of hydrogen into the steel depends on variables such as hydrogen concentration, temperature, applied or residual stress, microstructure, and surface finishing [152,169-172], and may be introduced into the steel from finishing processes including electroplating, forging, welding, corrosion, and cathodic protection system $[173,174]$.

$\mathrm{Fe}-\mathrm{Mn}-\mathrm{C}$ TWIP steels show superior elongation and strength due to deformation twinning [164], therefore they are highly suitable for automobile applications $[159,160]$. Various $\mathrm{Fe}-\mathrm{Mn}-\mathrm{C}$ austenitic steels, however, have reported HE in recent works [154,156-165]. Koyama et al. have reported an excellent overview of HE susceptibility of high-Mn steels, however the mechanistic effect of adding Al to TWIP steels has not been sufficiently investigated [167-175].

TWIP steel have been reported to be susceptible to hydrogen-delayed fracture (HDF) caused by HE after forming [176,177]. However, some grades of TWIP steels have shown immunity to HDF $[137,165]$. Additionally, addition of Al decreased the susceptibility to HDF or even imparted immunity $[178,179]$. The study by Noh et al. investigated the effect of grain size on $\mathrm{HE}$, concluding that grain refinement suppressed $\mathrm{HE}$ in the $\mathrm{Fe}-18 \mathrm{Mn}-1.5 \mathrm{Al}-0.6 \mathrm{C}$ TWIP steel $[180,181]$.

Negligible mechanical degradation has been observed using tensile tests with specimens pre-charged with hydrogen $[148,178,182,183]$. Little difference was observed by So et al. between the mechanical properties of $\mathrm{Fe}-18 \mathrm{Mn}-1.5 \mathrm{Al}-0.6 \mathrm{C}$ TWIP steel charged with different amounts of hydrogen contents and those without hydrogen charging [137]. The work of Ronevich et al. examined the different hydrogen contents on TWIP steels introduced by cathodic charging. Ultimately, the tensile properties, including yield stress, UTS, strain to failure, and strain hardening behavior, were nearly identical [182].

Hydrogen-induced fracture in TWIP steels was studied by Suh, who determined hydrogen experienced limited penetration, thus little change in mechanical properties was observed [183]. Contrarily, Koyama et al. discovered that mechanical properties of $\mathrm{Fe}-18 \mathrm{Mn}-0.6 \mathrm{C}$ and $\mathrm{Fe}-18 \mathrm{Mn}-1.2 \mathrm{C}$ TWIP steel decrease significantly in the presence of hydrogen [171]. Similarly, reductions were observed in elongation from $80 \%$ to $42 \%$, and UTS by $20 \%$ caused by hydrogen $[156,162,165]$.

The HE susceptibility is generally increased by strength increases in steels, presenting a significant challenge for AHSS [184,185]. Once a critical value is reached, hydrogen can induce a strength and ductility reduction. This critical hydrogen concentration differs depending on the steel grade [186]. HE is commonly studied by slow strain rate tensile testing on hydro-generated specimens [187]. Austenitic alloys are considered to be immune to this type of corrosion damage; however, stress or strain-induced martensite transformation of austenite, which takes place in TRIP-aided austenitic alloys, can be a reason for embrittlement. This may be attributed to the significant differences in solubility and diffusion rate of hydrogen in the body-centered cubic (bcc) and face-centered cubic (fcc) lattices, thus acting as hydrogen sinks, lowering hydrogen mobility, and increasing the concentration. It is difficult to reach hydrogen concentrations high enough to cause embrittlement in austenite due to its slow diffusion rate. It has been observed that the hydrogen concentration in the surface regions of high-Mn steel, however, is much higher than in the center zone [186].

Sheng et al. studied the cutting method on $\mathrm{HE}$ of $\mathrm{Fe}-20 \mathrm{Mn}-1 \mathrm{Al}-1.6 \mathrm{Cr}-0.35 \mathrm{C}$ TWIP steel, determining that high HE susceptibility of specimens prepared by the blanking method was attributed to high local dislocation density aided by the hydrogen-enhanced localized plasticity mechanism [188]. The effects of hydrogen on the nanomechanical properties of $\mathrm{Fe}-22 \mathrm{Mn}-0.6 \mathrm{C}$ TWIP steel was studied by Wang et al., and the change in nanohardness was attributed to hydrogen-enhanced lattice friction and the hydrogenreduced plastic zone size [189]. 
Delayed fracture may occur when the newly formed automotive elements are exposed to air. Cup forming tests are used to investigate the technological formability $[190,191]$. $\mathrm{Fe}-22 \mathrm{Mn}-0.6 \mathrm{C}$ steel cup was shown to undergo delayed fracture when exposed to air for seven days, despite the specimen showing no cracking during formation [191]. This is due to strain-induced martensite transformation during the cupping test in areas of high stress concentration. With $1.2 \mathrm{wt} . \%$ addition of $\mathrm{Al}$, the steel cup forms with increased amounts of mechanical twinning in place of $\gamma \rightarrow \alpha^{\prime}$ transformation.

The novel scanning Kelvin probe force microscopy (SKPFM) approach was successfully used for hydrogen detection in deformation twin plates of $\mathrm{Fe}-\mathrm{Mn}-\mathrm{C}$ austenitic TWIP steels [169]. Hydrogen stored in deformation twins persists in the material for a longer period than diffusible hydrogen in interstitial sites, vacancies, and dislocations, but displays significant mobility at room temperature. The difference in potential between the twins and the matrix is highest after an exposure time of $67 \mathrm{~h}$ and decreases with further exposure time. The potential difference between the twins and the matric shows the potential increase over the exposure time until $67 \mathrm{~h}$ and decrease between $67 \mathrm{~h}$ and $300 \mathrm{~h}$, relating to the evolution and disappearance of dark contrast as a function of the exposure time to the dry nitrogen atmosphere [169]. In another study, the SKP was used to characterize the potential distribution on the welded metal surface relating the microstructure with corrosion behavior [192]. A relationship between the different zones of the weld was observed in the potential as can be seen in Figure 24. Furthermore, the fusion zone (FZ) acted as the anode due to the lower surface potential, whereas the heat affected zone (HAZ) and bulk material (BM) constituted the cathode zone [192]. The preferential active area was found to be the FZ, this is in agreement with previous literature [193].
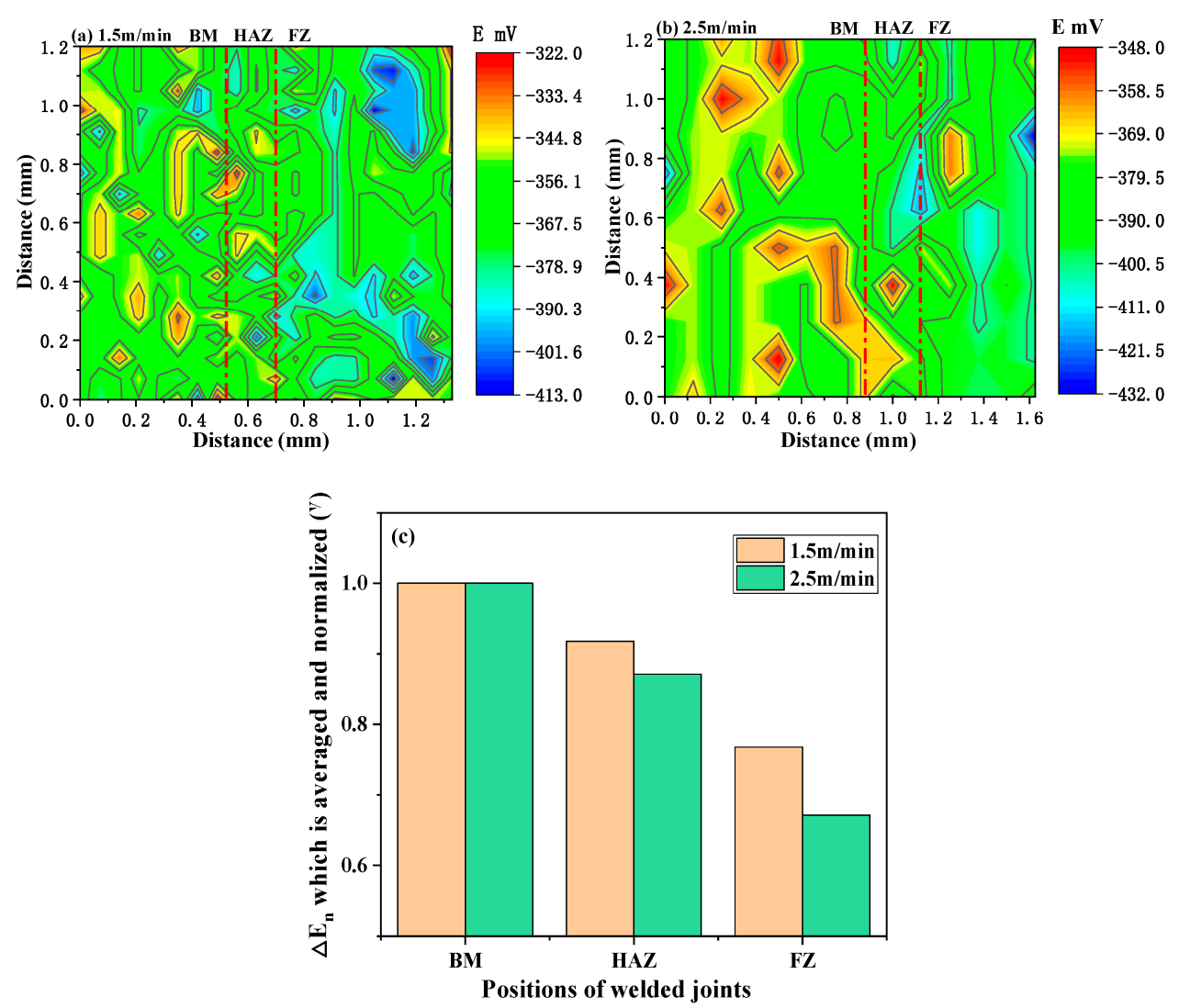

Figure 24. Volta potential distribution of welded joints under the welding speed of (a) $1.5 \mathrm{~m} / \mathrm{min}$ and (b) $2.5 \mathrm{~m} / \mathrm{min}$; and (c) the average surface potential of welded joint of $\mathrm{Fe}-18 \mathrm{Mn}-1.5 \mathrm{Al}-0.6 \mathrm{C}$ TWIP steel obtained via micro-area SKP [192]. 
The HE of $\mathrm{Fe}-(15-16) \mathrm{Mn}-0.6 \mathrm{C}, \mathrm{Fe}-22 \mathrm{M}-0.6 \mathrm{C}$ [194], $\mathrm{Fe}-15 \mathrm{Mn}-3 \mathrm{Al}-0.7 \mathrm{C}$ [195], and $\mathrm{Fe}-18 \mathrm{Mn}-0.6 \mathrm{C}$ [167] TWIP steels was triggered by the cup-forming tests and the consequent exposure in air. Similarly, tensile tests following electrochemical hydrogen charging showed HE in austenite as well, the mode of fracture was intergranular $[196,197]$. Tensile tests during charging was shown to produce considerable amounts of diffusible hydrogen, as shown by Koyama, a clear intergranular fracture in the $\mathrm{Fe}-18 \mathrm{Mn}-0.6 \mathrm{C}$ TWIP steel was observed [167]. Hydrogen was effectively introduced to the specimens during the tensile tests by simple diffusion as well as dislocation motions [158,198], resulting in a clear embrittlement phenomenon. Mobility of slip dislocations [150], the behavior of martensitic transformation [195,196], the deformation twinning [160,161], and the cohesive energy of the grain boundary are affected by hydrogen in austenitic steels $[199,200]$.

\section{Elevated Temperature Oxidation of High-Mn TWIP Steels}

The oxidation behavior of austenitic $\mathrm{Fe}-30 \mathrm{Mn}-5 \mathrm{Al}-0.5 \mathrm{C}$ alloy was studied in air in the $600-900{ }^{\circ} \mathrm{C}$ temperature range by Pérez et al. [200], the alloy exhibited good oxidation resistance below $700{ }^{\circ} \mathrm{C}$. The low oxidation resistance above $700{ }^{\circ} \mathrm{C}$ was attributed to the occurrence of internal oxidation. High-Mn alloys form complex oxide scale comprising stratified, Mn-rich oxides. Decreasing the amount of Mn increases the oxidation resistance, and in addition, increasing the temperature, causes the limit of $\mathrm{Al}$ to form a protective scale decrease [200]. Different mechanisms have been proposed to explain these alloys oxidation mechanisms, Sato et al. proposed that oxidation is governed by the supply of $\mathrm{Al}, \mathrm{Mn}, \mathrm{Fe}$, and $\mathrm{O}_{2}$ to the alloy surface to form protective scales [38].

Analysis of the cross-section of the oxide layer developed after high temperature oxidation of austenitic $\mathrm{Fe}-\mathrm{Mn}-\mathrm{Al}-\mathrm{C}$ TWIP steel exhibited four distinct layers in the scale with $32 \pm 5 \mu \mathrm{m}$ thickness. Figure 25 shows the cross section and the depth profile of the oxide scale containing a $2 \mu \mathrm{m}$ thick outer layer of Mn oxide. The presence of Fe in solid solutions was determined via X-ray diffraction (XRD) analysis in the formation of $\mathrm{Mn}_{2} \mathrm{O}_{3}$, a homogeneous (Mn,Fe)-rich oxide layer developed underneath the $\mathrm{Mn}_{2} \mathrm{O}_{3}$ [200].

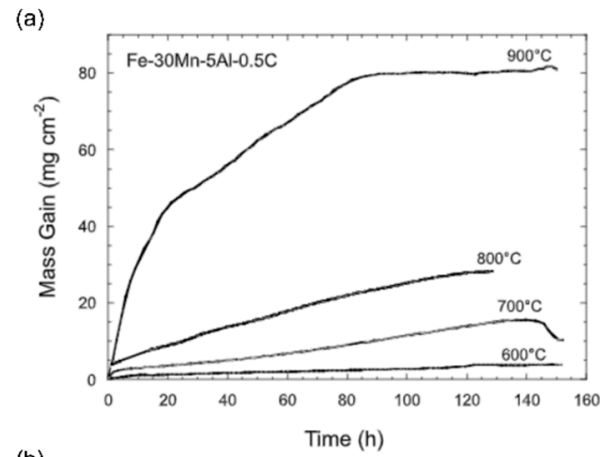

(b)

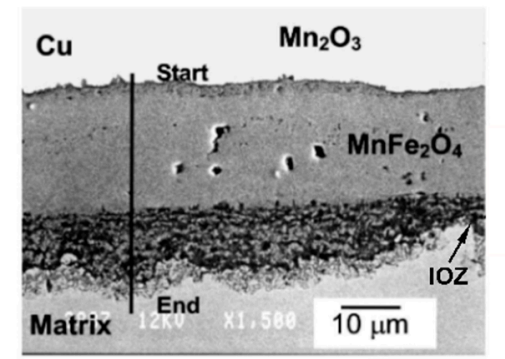

Figure 25. Gravimetric corrosion study (a) mass gain versus time for $\mathrm{Fe}-30 \mathrm{Mn}-5 \mathrm{Al}$ alloy oxidized in air between $600{ }^{\circ} \mathrm{C}$ and $900{ }^{\circ} \mathrm{C}$, and (b) cross-section and the corresponding depth profile of the oxide scale after $100 \mathrm{~h}$ at $600{ }^{\circ} \mathrm{C}$ [200]. (Reproduced with permission from refs. [200]. Copyright (2002), Elsevier). 
The focus on high-temperature oxidation has been on $\mathrm{Fe}-\mathrm{Mn}-\mathrm{Al}-\mathrm{C}$ alloys, due to their potential to replace $\mathrm{Fe}-\mathrm{Cr}-\mathrm{Ni}$ SS alloy [104], cryogenic and nonmagnetic steels [105,201]. The oxidation of the new austenitic $\mathrm{Fe}-15 \mathrm{Mn}-1.5 \mathrm{Al}-0.5 \mathrm{C}$ alloy was studied at extremely high temperature up to $1250{ }^{\circ} \mathrm{C}$ and was found that the oxide can be divided into two zones, the external and internal oxide zones. The external zone composition was ascertained to consist of $\mathrm{Mn}_{2} \mathrm{O}_{3}, \mathrm{Mn}_{3} \mathrm{O}_{4},(\mathrm{Fe}, \mathrm{Mn}) \mathrm{O}$ and $\mathrm{MnAl}_{2} \mathrm{O}_{4}$ phases, while the internal zone was found to consist of $\mathrm{MnAl}_{2} \mathrm{O}_{4}$ formed by selective oxidation of $\mathrm{Mn}$ and $\mathrm{Al}$. The $\gamma$-austenite matrix was transformed to $\alpha$-ferrite and $\varepsilon$-martensite phases by the selective oxidation of $\mathrm{Mn}$ [202]. Fe-(5-10)Mn-(6-10)Al alloy developed continuous protective alumina scales and are totally ferritic [202].

The oxidation of $\mathrm{Fe}-30 \mathrm{Mn}-10 \mathrm{Al}-1.0 \mathrm{Si}$ alloy at high $\mathrm{O}_{2}$ pressure of $10.13 \mathrm{~Pa}$ immediately leads to formation of oxide nodules, and surface exposure to air at $800-1100{ }^{\circ} \mathrm{C}$ showed the formation of a dense and protective $\mathrm{Al}_{2} \mathrm{O}_{3}$ scale [203]. The oxidation kinetics of $\mathrm{Fe}-5.5 \mathrm{Al}-0.55 \mathrm{C}$ alloy after $24 \mathrm{~h}$ oxidation at 600,800 , and $1000{ }^{\circ} \mathrm{C}$ presented simple, three- and two-stage parabolic laws, respectively. Carbides were observed on the alloy at all temperatures except $600^{\circ} \mathrm{C}$; moreover, a carbide-free zone was observed on oxidized specimens at 800 and $1000{ }^{\circ} \mathrm{C}$, resulting from carbide stability at different oxidation temperatures [204]. $\mathrm{Fe}-7.5 \mathrm{Al}-0.65 \mathrm{C}$ alloy was oxidized at $600-900{ }^{\circ} \mathrm{C}$ for $24 \mathrm{~h}$, and was also classified into two groups, and the change in the oxidation behavior observed between 600 and $700-900{ }^{\circ} \mathrm{C}$ was related to the effect of the temperature on the diffusion of $\mathrm{Al}$ in the alloy [205]. Internal oxidation occurred beneath the nodules formed on Fe-7.5Al-0.65C alloy after oxidation at $600{ }^{\circ} \mathrm{C}$, but no internal oxidation was observed in the specimens of this alloy after $24 \mathrm{~h}$ oxidation at $700-900{ }^{\circ} \mathrm{C}$.

The oxidation behavior of the austenitic $\mathrm{Fe}-30 \mathrm{Mn}-5 \mathrm{Al}-(3-9) \mathrm{Cr}$ alloy was studied in air between 600 and $900{ }^{\circ} \mathrm{C}$. The alloy with the highest $\mathrm{Cr}$ content showed the best oxidation resistance. Chromium addition delayed the beginning of internal oxidation for longer times and/or higher temperatures [206]. Lins et al. studied the oxidation at high temperature from 600 to $900{ }^{\circ} \mathrm{C}$ of $\mathrm{Fe}-31.8 \mathrm{Mn}-6.09 \mathrm{Al}-1.6 \mathrm{Si}-0.40 \mathrm{C}$, and concluded that the alloy showed good oxidation resistance at 600 and $700{ }^{\circ} \mathrm{C}$ [207].

\section{Corrosion Behavior of Welded High-Mn TWIP Steels}

The joining of sheet metal components is a critical issue regarding automotive applications and car body parts. Specifically, fusion-welding causes major changes to the material in the fusion zone (FZ) and heat-affected-zone (HAZ). Furthermore, regarding the production of TWIP steel sheets, the effects of grain size ought to be considered. The mechanical properties of welded TWIP steels have been examined in literature [208-213]. Despite the significance of the corrosion behavior of TWIP steel welded joints, it has scarcely been studied in literature $[83,214]$.

Recently, the authors have studied the corrosion behavior of resistance-spot-welded (RSW) high-Mn austenitic Fe-30Mn-5Al-6Cr-0.5C TWIP steel in a 3.5 wt.\% NaCl solution [193]. The Nyquist plots indicate a capacitive behavior for the TMP specimen and the FZ and base-material (BM) specimens at high-frequencies; additionally, an inductive behavior was observed for the BM specimen at low-frequencies, see Figure 26. Micro-segregation can lead to $\mathrm{Cr}$-depleted zones, increasing pitting corrosion susceptibility, which frequently influences the presence of an inductive loop on the Nyquist plot, attributed to the presence of corrosion reaction intermediates or the relaxation of surface adsorbed species such as chlorides [193]. 


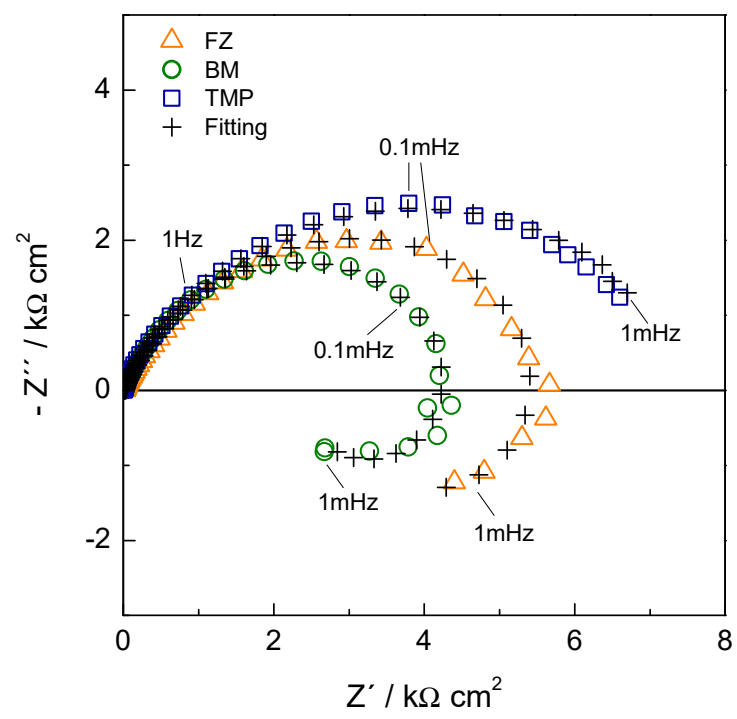

Figure 26. Nyquist plots for the fusion zone (FZ), base metal (BM), and thermo-mechanically processed (TMP) Fe-30Mn-5Al-6Cr-0.5C TWIP specimen in $3.5 \mathrm{wt} \% \mathrm{NaCl}$ solution at room temperature [193]. (Reproduced with permission from refs. [193]. Copyright (2020), Taylor \& Francis).

\section{Tribocorrosion of High-Mn TWIP Steels}

The role of SFE in two-body abrasive wear of austenitic steels was studied by Zambrano et al. applying a pin-abrasion test with 220 grit garnet paper as the counter body and three austenitic steels, $\mathrm{Fe}-\mathrm{Mn}-\mathrm{Al}-\mathrm{C}$ (medium SFE), Hadfield steel (lowest SFE), and AISI 316L SS (highest SFE). Ultimately, the study showed $\mathrm{Fe}-\mathrm{Mn}-\mathrm{Al}-\mathrm{C}$ steel exhibited higher wear resistance compared to AISI 316L SS, yet lower than Hadfield steel [214]. When tested at the highest load, however, all three steel types showed similar wear resistance. The steel with the lowest SFE had the highest abrasive wear resistance and the steel with the highest SFE had the lowest abrasive wear resistance, as shown in Figure 27 [214]. The main wear mechanisms were described as microcutting and microploughing, and a transition from microploughing to microcutting occurred as the normal load was increased. The SFE could be a more general parameter to characterize the wear resistance in austenitic steels [215-217].

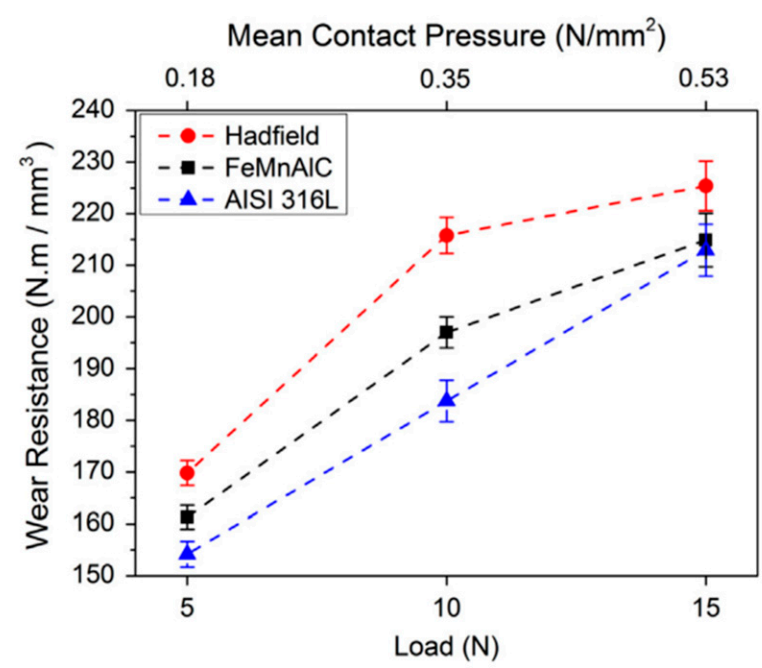

Figure 27. The effect of normal load on the wear resistance of the Fe-Mn-Al-C steel, Hadfield steel, and AISI 316L stainless steel (the bars correspond to the interval of confidence at 95\%) [214]. (Reproduced with permission from refs. [214]. Copyright (2016), Elsevier). 
The study by Hamada et al. discovered that Ni-P coatings could substantially improve the corrosion performance and surface hardness of Fe-25Mn-3Al TWIP steel [218]. Improvements in the corrosion resistance in sulfuric acid solution for the Ni-P coated steel was observed compared to uncoated TWIP steel. The lowest $i_{\text {corr }}$ was found for the as-plated Ni-P TWIP steel samples $\left(20 \mu \mathrm{A} \mathrm{cm}{ }^{-2}\right)$ compared to Ni-P coated TWIP samples annealed at $350{ }^{\circ} \mathrm{C}$ and $700{ }^{\circ} \mathrm{C}$, with $i_{\text {corr values of }} 81 \mu \mathrm{A} \mathrm{cm}^{-2}$ and $33 \mu \mathrm{A} \mathrm{cm}^{-2}$, respectively. Additionally, the Berkovich indentation tests showed a plastic material devoid of cracks and with a hardness and elastic modulus significantly higher than that of substrate TWIP steel, see Figure 28 [218]. The formation of deleterious $\mathrm{Ni}_{3} \mathrm{P}$ particles was found to decrease performance and enhance diffusion of Mn towards the surface, thus forming Mn oxides and increasing the corrosion rate of the substrate.

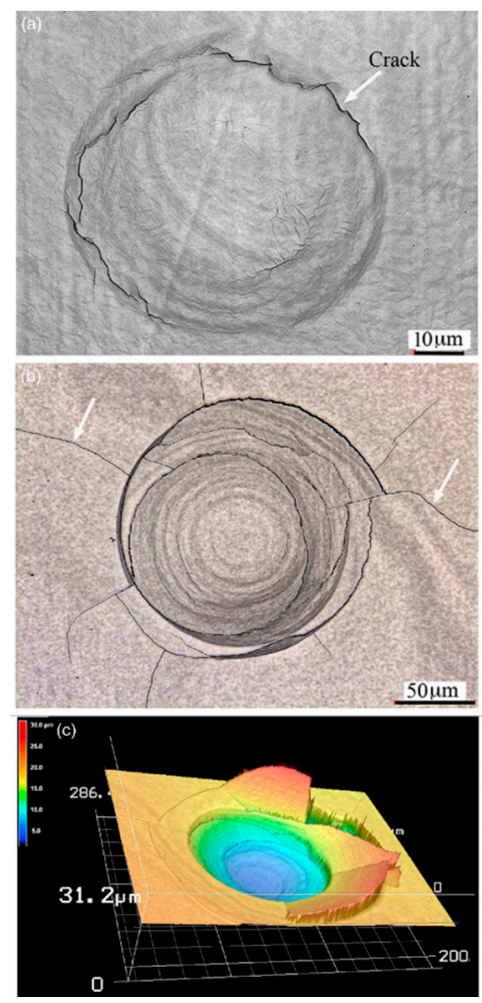

Figure 28. Laser-optical micrograph of the PT coating at $350{ }^{\circ} \mathrm{C}$ showing crack formation under a ball indentation after different applied loads: (a) $6 \mathrm{~N}$, (b) $20 \mathrm{~N}$; and (c) 3-dimensional profile after loading 20 N [218]. (Reproduced with permission from refs. [218]. Copyright (2015), Elsevier).

\section{Corrosion of High-Mn TWIP Steels in Harsh Environments}

$\mathrm{Fe}-\mathrm{Mn}-\mathrm{Al}-\mathrm{C}$ steel was first developed in late 1950s for the use of cryogenic or highly corrosive environments by replacing the high $\mathrm{Fe}-\mathrm{Ni}-\mathrm{Cr}$ SS cryogenic [219], and recently reappraised as a promising candidate for austenitic SS by adding some content of Cr [102].

The first research reported on $\mathrm{Fe}-\mathrm{Mn}-\mathrm{Al}-\mathrm{C}$ alloys for cryogenic applications that were intended to substitute $\mathrm{Fe}-\mathrm{Cr}-\mathrm{Ni}$ SSs was carried out in the 80's [66]. More recent studies have reported on the development of new TWIP steel alloys for cryogenic devices [219]. Manganese is added to replace $\mathrm{Ni}$ and obtain an austenitic microstructure, and $\mathrm{Al}$ has a similar role as $\mathrm{Cr}$. Improvement of corrosion resistance by $\mathrm{Al}$ results from the formation of thin, stable oxide layers. It was found that $\mathrm{Fe}-\mathrm{Mn}-\mathrm{Al}-\mathrm{C}$ alloys show inferior corrosion resistance compared to $\mathrm{Fe}-\mathrm{Cr}-\mathrm{Ni}$ SSs and can be used as a substitute in specific applications [220]. 


\section{Corrosion of Additively Manufactured High-Mn TWIP Steels}

Additive manufacturing (AM) is an emergent technology that can be used for fabricating structural high-Mn TWIP steels; alloying with Mn could adjust the degradation of Fe, thus Mn imparts corrosion protection [221-223]. The use of AM (3D printing) of Fe-30Mn alloys for various uses including biomedical applications, particularly biodegradable scaffolds as a bone scaffold material, was proposed by Chou et al. [223]. Three-dimensional printed $\mathrm{Fe}-30 \mathrm{Mn}$ alloys exhibit high amounts of corrosion in Hank's solution (pH 7.4) due to the increased surface porosity of the materials introduced in the AM process. However, this is a topic that needs further development as the technology keeps improving, enhancing the properties as well as increasing the possible applications of the different alloys.

The development of bioresorbable implants continues to be a significant challenge in the biomedical industry due to improper dissolution rates or deficient strength of many candidate alloys. Niendorf et al. investigated selected laser melting (SLM) technology to manufacture Fe-22Mn-0.6C steel alloy with additions of silver $(\mathrm{Ag})$ alloying element to increase the corrosion properties of Fe-22Mn-0.6C TWIP steel alloy obtained by AM, which allows Ag to release during degradation. Particles of $\mathrm{Ag}(5 \mathrm{wt} . \%)$ served as cathodic sites, which promoted micro-galvanic corrosion, while simultaneously not affecting the mechanical properties [224]. The local corrosion difference of TWIP-5Ag alloy could be demonstrated by SKPFM on the Ag agglomerates under atmospheric conditions [224].

Furthermore, the corrosion behavior of SLM produced steel and high Mn steel was investigated in a study performed by Shuai et al. [225]. Figure 29a shows an enhanced corrosion rate of the high $\mathrm{Mn}$ steel associated with galvanic corrosion. This galvanic coupling effect is due to the potential difference among the different phases formed and the non-uniform distribution of $\mathrm{Mn}$ in the grain boundaries [225]. Figure 29b shows the SEM microscopy of the corroded surface of the high Mn steel. Corrosion products can be observed in the surface, evidencing the higher corrosion rate and the local corrosion promoted by the galvanic micro-coupling [225]. However, this study does not cover the corrosion mechanisms of additively manufactured high Mn steel. Further research efforts are necessary to disentangle the corrosion mechanisms of additively manufactured steels in order to improve alloy design, manufacturing techniques, or corrosion protection strategies.
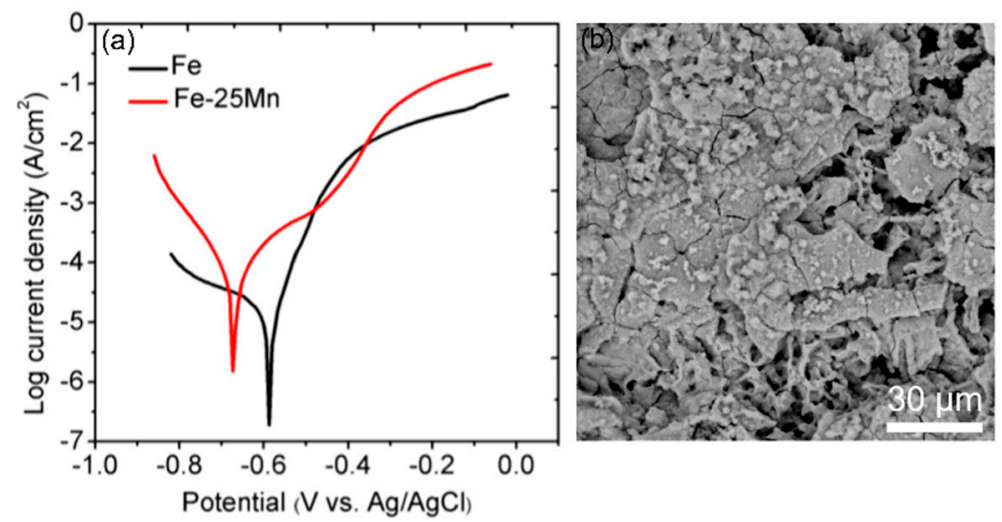

Figure 29. High Mn steel produced via SLM: (a) Potentiodynamic polarization curve in simulated body fluid, and (b) SEM micrography of the corroded specimen after polarization [225].

Significantly, Mn is an essential element for the human body [225]. Fe-Mn alloys were examined to achieve an alloy with mechanical properties similar to AISI 316L SS and degradation performance superior to pure Fe [226]. The yield strength and elongation of alloys was comprised between $234 \mathrm{MPa}$ and $32 \%$ for Fe-35Mn alloy to $421 \mathrm{MPa}$ and $7.5 \%$ for the $\mathrm{Fe}-20 \mathrm{Mn}$ alloy. The corrosion rate, however, was higher than pure Fe. The work of Heiden et al. involves the design of degradable fracture fixation implants for implementation of hard tissues, and the work shows promising results using $\mathrm{Fe}-33 \mathrm{Mn}$ bioresorbable alloy [227], as corroborated by Shuai et al. [225]. 


\section{Summary and Conclusions}

Undoubtedly, the development of low-cost $\mathrm{Fe}-\mathrm{Mn}-\mathrm{Al}-\mathrm{C}$ alloy with high corrosion resistance and excellent mechanical properties is still a challenging issue and a compromise should be achieved amongst its alloying design, mechanical behavior, anti-oxidation ability, and corrosion resistance in certain commercial applications. In general, $\mathrm{Fe}-\mathrm{Mn}$-based alloys can passivate in oxidizing acid, neutral, and basic solutions, but cannot passivate in reducing acid or solution containing active chloride.

The passive film formed on the $\mathrm{Fe}-24 \mathrm{Mn}-4 \mathrm{Al}-5 \mathrm{Cr}$ alloy in a $1 \mathrm{M} \mathrm{Na}_{2} \mathrm{SO}_{4}$ solution consisted of three regions: Bounded water and hydroxides present at the surface; the outer portion of film made up of a mixture of $\mathrm{Fe}, \mathrm{Mn}, \mathrm{Cr}$, and $\mathrm{Al}$ oxides; and a transition region consisting of low valence oxides and metallic $\mathrm{Fe}, \mathrm{Mn}, \mathrm{Cr}$, and $\mathrm{Al}$ between the passive film and the matrix.

Generally, alloying elements such as $\mathrm{Cr}$ and $\mathrm{Al}$ provide passive film formation. Chromium addition showed a beneficial effect on TWIP steel corrosion performance, however high $\mathrm{Cr}$ content was shown to cause phase-segregation, thus reducing the corrosion resistance. The results indicate that TMP diminishes corrosion resistance. High-Al TWIP steels exhibited salt-film precipitation as a passivation mechanism. Al promotes passivity via the formation of a passive layer of $\mathrm{Al}_{2} \mathrm{O}_{3}$ film. Similarly, lower contents of $\mathrm{Cr}$ enhance passivity. However, higher contents (i.e., $6-9 \mathrm{wt} . \%$ ) are detrimental due to the $\mathrm{Cr}$ causing phase-segregations, generating nucleation points for pitting corrosion. Regarding $\mathrm{Si}$, the formation of intermetallics such as $\mathrm{Fe}_{3} \mathrm{Al}-\mathrm{Si}$ impart passivity. Furthermore, an increase in the $E_{\mathrm{pit}}$ and an extension of the passive region is observed. Molybdenum affects the polarity of the passive film via formation of molybdates as well as a creation a bipolar interface that promotes repassivation via deactivation of pits growth. Furthermore, Mo enhances the corrosion resistance forming a $\mathrm{MoO}_{3}$ oxide layer that converts to $\mathrm{MoO}_{4}{ }^{2-}$ in the interface. This limits the flux of $\mathrm{OH}^{-}$and $\mathrm{Cl}^{-}$ions into the surface. Mn severely affects the corrosion resistance due to its higher dissolution kinetics.

An important corrosion mechanism in TWIP steel is the galvanic-coupling effect due to the formation of different phases. $\mathrm{MnS}$ and $\mathrm{MnO}_{3} \mathrm{~S}$ inclusions on TWIP act as galvanic anodes. Secondary phases formed during thermal treatment (ferrite, $\alpha^{\prime}$ - and $\varepsilon$-martensite) and as a result of cold-straining ( $\alpha^{\prime}$ - or $\varepsilon$-martensite) increases the corrosion current density, due to the galvanic coupling between secondary phases and the austenite matrix. Annealing treatments cause faster steel dissolution because of galvanic corrosion, induced by different electrochemical potential of the deformed and the supersaturated regions on the TWIP steel microstructure. The strain-aged samples display the highest corrosion rate due to the galvanic cell created by the coupling of ferrite with the austenite matrix.

Micro-segregation induces $\mathrm{Cr}$-depleted zones, thus increasing pitting corrosion susceptibility of TWIP steel. Increased degree of cold-working (30-40\%) can lead to a dramatically decrease in corrosion resistance, due to pitting processes. Nevertheless, the deterioration of the corrosion resistance of TWIP steel is often related to the chemical composition of high-Mn steels rather than to the effect of cold deformation.

The high hydrogen embrittlement susceptibility of TWIP steel is imparted by the high local dislocation density along with the hydrogen-enhanced localized plasticity mechanism.

Author Contributions: Conceptualization, D.M.B.; methodology, D.M.B., J.R., J.B., and U.M.; resources, D.M.B.; writing-original draft preparation, D.M.B., J.R., J.B., and U.M.; writing-review and editing, D.M.B., J.R., J.B., and U.M.; visualization, D.M.B.; supervision, D.M.B.; project administration, D.M.B.; funding acquisition, D.M.B. All authors have read and agreed to the published version of the manuscript.

Funding: The authors acknowledge funding from Firestone Research, grant number 639430, and The University of Akron.

Institutional Review Board Statement: Not applicable.

Informed Consent Statement: Not applicable. 
Data Availability Statement: Not applicable.

Acknowledgments: The authors wish to express their most sincere gratitude to J.M. Bastidas for fruitful and valuable discussions.

Conflicts of Interest: The authors declare no conflict of interest.

\section{Abbreviations}

\begin{tabular}{|c|c|}
\hline AES & Auger electron spectroscopic \\
\hline AHSS & Advanced high-strength steels \\
\hline $\mathrm{AM}$ & Additive manufacturing \\
\hline bcc & Body-centered cubic \\
\hline $\mathrm{BM}$ & Base material \\
\hline CG & Coarse-grained \\
\hline $\mathrm{CP}$ & Complex phase \\
\hline $\mathrm{CPP}$ & Cyclic potentiodynamic polarization \\
\hline DP & Dual-phase \\
\hline EBSD & Electron backscattered diffraction \\
\hline$E_{\text {corr }}$ & Corrosion potential \\
\hline$E_{\mathrm{f}}$ & Flade potential \\
\hline EIS & Electrochemical impedance spectroscopy \\
\hline$E_{\text {pit }}$ & Pitting potential \\
\hline FB & Ferritic-bainitic \\
\hline fcc & Face-centered cubic \\
\hline FG & Fine-grained \\
\hline FZ & Fusion zone \\
\hline HAZ & Heat-affected-zone \\
\hline $\mathrm{HE}$ & Hydrogen embrittlement \\
\hline $\mathrm{HF}$ & Hot formed \\
\hline HDE & Hydrogen-delayed fracture \\
\hline HNSS & Nickel-free high-N SS \\
\hline HSLA & High-strength low alloy \\
\hline HSS & High strength steels \\
\hline$i_{\text {corr }}$ & Corrosion current density \\
\hline IF & Interstitial-free \\
\hline$i_{\text {pass }}$ & Passive current density \\
\hline PFHT & Post-forming heat-treatable \\
\hline $\mathrm{Rp}$ & Polarization resistance \\
\hline RSW & Resistance-spot-welded \\
\hline SCC & Stress corrosion cracking \\
\hline SEM & Scanning electron microscopy \\
\hline SFE & Stacking fault energy \\
\hline SHE & Standard hydrogen electrode \\
\hline SIMS & Secondary ion mass spectroscopy \\
\hline SKPFM & Scanning Kelvin probe force microscopy \\
\hline SLM & Selected laser melting \\
\hline SS & Stainless steel \\
\hline TEM & Transmission electron microscopy \\
\hline TMP & Thermo-mechanically processed \\
\hline TRIP & Transformation-induced plasticity \\
\hline TWIP & Twinning-induced plasticity \\
\hline UHSS & Ultra-high strength steels \\
\hline UTS & Ultimate tensile strength \\
\hline$v$ & Potential scan rate \\
\hline$v_{\text {corr }}$ & Corrosion rate \\
\hline XPS & X-ray photoelectron spectroscopy \\
\hline XRD & X-ray diffraction \\
\hline
\end{tabular}




\section{References}

1. Matlock, D.K.; Speer, J.G. Third Generation of AHSS: Microstructure Design Concepts. In Microstructure and Texture in Steels; Haldar, A., Suwas, S., Bhattacharjee, D., Eds.; Springer: New York, NY, USA, 2009; pp. 185-205.

2. Cornette, D. SAE Technical Paper of the SAE World Congress; SAE International: Detroit, MI, USA, 2002.

3. Thorpe, M.D.; Adam, H. SAE Technical Paper of the SAE World Congress; SAE International: Detroit, MI, USA, 2002.

4. Allain, S.; Chateau, J.-P.; Bouaziz, O. A physical model of the twinning-induced plasticity effect in a high manganese austenitic steel. Mater. Sci. Eng. A 2004, 387-389, 143-147. [CrossRef]

5. Bouaziz, O.; Allain, S.; Scott, C. Effect of grain and twin boundaries on the hardening mechanisms of twinning-induced plasticity steels. Scr. Mater. 2008, 58, 484-487. [CrossRef]

6. De Cooman, B.C.; Chin, K.; Kim, J. High Mn TWIP Steels for Automotive Applications. In New Trends and Developments in Automotive System Engineering; Chiaberge, M., Ed.; InTech Europe: Rijeka, Croatia, 2011; pp. 101-128.

7. Pierce, D.T.; Jiménez, J.A.; Bentley, J.; Raabe, D.; Wittig, J.E. The influence of stacking fault energy on the microstructural and strain-hardening evolution of Fe-Mn-Al-Si steels during tensile deformation. Acta Mater. 2015, 100, 178-190. [CrossRef]

8. Bouaziz, O.; Guelton, N. Modelling of TWIP effect on work-hardening. Mater. Sci. Eng. A 2001, 319-321, 246-249. [CrossRef]

9. Allain, S.; Chateau, J.-P.; Bouaziz, O.; Migot, S.; Guelton, N. Correlations between the calculated stacking fault energy and the plasticity mechanisms in Fe-Mn-C alloys. Mater. Sci. Eng. A 2004, 387-389, 158-162. [CrossRef]

10. Cohen, J.B.; Weertman, J. A dislocation model for twinning in f.c.c. metals. Acta Metall. 1963, 11, 996-998. [CrossRef]

11. Venables, J.A. On dislocation pole models for twinning. Philos. Mag. 1974, 30, 1165-1169. [CrossRef]

12. Chen, S.; Rana, R.; Haldar, A.; Ray, R.K. Current state of Fe-Mn-Al-C low density steels. Prog. Mater. Sci. 2017, 89, 345-391. [CrossRef]

13. Jacob, R.J.; Sankaranarayanan, S.R.; Babu, S.P.K. Recent advancements in manganese steels-A review. Mater. Today Proc. 2020, 27, 2852-2858. [CrossRef]

14. De Cooman, B.C.; Kwon, O.; Chin, K.-G. State-of-the-knowledge on TWIP steel. Mater. Sci. Technol. 2012, 28, 513-527. [CrossRef]

15. Neu, R.W. Performance and characterization of TWIP steels for automotive applications. Mater. Perform. Charact. 2013, 2, 20130009. [CrossRef]

16. Remy, L. Temperature variation of the intrinsic stacking fault energy of a high manganese austenitic steel. Acta Metall. 1977, 25, 173-179. [CrossRef]

17. Remy, L. The interaction between slip and twinning systems and the influence of twinning on the mechanical behavior of fcc metals and alloys. Metall. Trans. A 1981, 12, 387-408. [CrossRef]

18. Remy, L. Kinetics of f.c.c. deformation twinning and its relationship to stress-strain behaviour. Acta Metall. 1978, 26, 443-451. [CrossRef]

19. Remy, L. Twin-slip interaction in f.c.c. crystals. Acta Metall. 1977, 25, 711-714. [CrossRef]

20. Remy, L.; Pineau, A.; Thomas, B. Temperature dependence of stacking fault energy in close-packed metals and alloys. Mater. Sci. Eng. 1978, 36, 47-63. [CrossRef]

21. Remy, L.; Pineau, A. Twinning and strain-induced F.C.C. $\rightarrow$ H.C.P. transformation in the Fe-Mn-Cr-C system. Mater. Sci. Eng. 1977, 28, 99-107. [CrossRef]

22. Chalant, G.; Remy, L. The slip character and low cycle fatigue behaviour: The influence of F.C.C. twinning and strain-induced F.C.C. $\rightarrow$ H.C.P. martensitic transformation. Acta Metall. 1980, 28, 75-88. [CrossRef]

23. Bouaziz, O.; Allain, S.; Scott, C.P.P.; Cugy, P.; Barbier, D. High manganese austenitic twinning induced plasticity steels: A review of the microstructure properties relationships. Curr. Opin. Solid State Mater. Sci. 2011, 15, 141-168. [CrossRef]

24. Keeler, S.; Kimchi, M.; Mooney, P.J. Advance High-Strength Steel Applications Guidelines, Version 6.0; World Auto Steel: Middletown, OH, USA, 2017.

25. Barbier, D.; Gey, N.; Allain, S.; Bozzolo, N.; Humbert, M. Analysis of the tensile behavior of a TWIP steel based on the texture and microstructure evolutions. Mater. Sci. Eng. A 2009, 500, 196-206. [CrossRef]

26. Idrissi, H.; Renard, K.; Ryelandt, L.; Schryvers, D.; Jacques, P.J. On the mechanism of twin formation in Fe-Mn-C TWIP steels. Acta Mater. 2010, 58, 2464-2476. [CrossRef]

27. Misra, R.D.K.; Kumar, B.R.; Somani, M.; Karjalainen, P. Deformation processes during tensile straining of ultrafine/nanograined structures formed by reversion in metastable austenitic steels. Scr. Mater. 2008, 59, 79-82. [CrossRef]

28. Grässel, O.; Krüger, L.; Frommeyer, G.; Meyer, L.W. High strength Fe-Mn-(Al, Si) TRIP/TWIP steels development-PropertiesApplication. Int. J. Plast. 2000, 16, 1391-1409. [CrossRef]

29. Gutierrez-Urrutia, I.; Zaefferer, S.; Raabe, D. The effect of grain size and grain orientation on deformation twinning in a Fe-22wt.\% Mn-0.6wt.\% C TWIP steel. Mater. Sci. Eng. A 2010, 527, 3552-3560. [CrossRef]

30. Vercammen, S.; Blanpain, B.; de Cooman, B.C.; Wollants, P. Cold rolling behaviour of an austenitic Fe-30Mn-3Al-3Si TWIP-steel: The importance of deformation twinning. Acta Mater. 2004, 52, 2005-2012. [CrossRef]

31. Soulami, A.; Choi, K.S.; Shen, Y.F.; Liu, W.N.; Sun, X.; Khaleel, M.A. On deformation twinning in a 17.5\% Mn-TWIP steel: A physically based phenomenological model. Mater. Sci. Eng. A 2011, 528, 1402-1408. [CrossRef]

32. Yu, Q.; Shan, Z.-W.; Li, J.; Huang, X.; Xiao, L.; Sun, J.; Ma, E. Strong crystal size effect on deformation twinning. Nature 2010, 463, 335-338. [CrossRef]

33. Wei, Y.; Li, Y.; Zhu, L.; Liu, Y.; Lei, X.; Wang, G.; Wu, Y.; Mi, Z.; Liu, J.; Wang, H.; et al. Evading the strength-ductility trade-off dilemma in steel through gradient hierarchical nanotwins. Nat. Commun. 2014, 5, 3580. [CrossRef] 
34. Li, Z.; Pradeep, K.G.; Deng, Y.; Raabe, D.; Tasan, C.C. Metastable high-entropy dual-phase alloys overcome the strength-ductility trade-off. Nature 2016, 534, 227-230. [CrossRef]

35. Lu, K.; Lu, L.; Suresh, S. Strengthening materials by engineering coherent internal boundaries at the nanoscale. Science 2009, 324, 349-352. [CrossRef]

36. Lee, Y.-K.; Choi, C. Driving force for $\gamma \rightarrow \varepsilon$ martensitic transformation and stacking fault energy of $\gamma$ in Fe-Mn binary system. Metall. Mater. Trans. A 2000, 31, 355-360. [CrossRef]

37. Mahajan, S.; Chin, G.Y. Formation of deformation twins in f.c.c. crystals. Acta Metall. 1973, 21, 1353-1363. [CrossRef]

38. Sato, K.; Tanaka, K.; Inoue, Y. Determination of the $\alpha / \gamma$ equilibrium in the iron rich portion of the Fe-Mn-Al system. ISIJ Int. 1989, 29, 788-792. [CrossRef]

39. Sugimoto, K.; Kikuchi, R.; Hashimoto, S. Development of high strength low alloy TRIP-aided steels with annealed martensite matrix. Steel Res. 2002, 73, 253-258. [CrossRef]

40. Dumay, A.; Chateau, J.-P.P.; Allain, S.; Migot, S.; Bouaziz, O. Influence of addition elements on the stacking-fault energy and mechanical properties of an austenitic Fe-Mn-C steel. Mater. Sci. Eng. A 2008, 483-484, 184-187. [CrossRef]

41. Yoo, J.D.; Park, K.-T.T. Microband-induced plasticity in a high Mn-Al-C light steel. Mater. Sci. Eng. A 2008, 496, 417-424. [CrossRef]

42. Cheng, W.-C.; Lin, Y.-S.; Chen, K.-F. The formation of ferrite quenching twins in a body-centered cubic Fe-Mn-Al alloy during high-temperature quenching. Scr. Mater. 2014, 81, 36-39. [CrossRef]

43. Cheng, W.-C.; Lai, C.-K. Observing massive phase transformation in a Fe-Mn-Al alloy. Scr. Mater. 2006, 55, 783-786. [CrossRef]

44. Charles, J.; Berghézan, A.; Lutts, A. Structure and mechanical properties of high-alloy manganese-aluminum steels. J. Phys. Colloq. 1982, 43, C4-C435. [CrossRef]

45. Kim, Y.G.; Park, Y.S.; Han, J.K. Low temperature mechanical behavior of microalloyed and controlled-rolled Fe-Mn-Al-C-X alloys. Metall. Trans. A 1985, 16, 1689-1693. [CrossRef]

46. Kim, Y.G.; Han, J.M.; Lee, J.S. Composition and temperature dependence of tensile properties of austenitic Fe-Mn-Al-C alloys. Mater. Sci. Eng. A 1989, 114, 51-59. [CrossRef]

47. Schramm, R.E.; Reed, R.P. Stacking fault energies of seven commercial austenitic stainless steels. Metall. Trans. A 1975, 6, 1345-1351. [CrossRef]

48. Rosalbino, F.; Carlini, R.; Parodi, R.; Zanicchi, G.; Scavino, G. Investigation of passivity and its breakdown on Fe3Al-Si and Fe3Al-Ge intermetallics in chloride-containing solution. Corros. Sci. 2014, 85, 394-400. [CrossRef]

49. Park, J.H.; Seo, H.S.; Kim, K.Y.; Kim, S.J. The effect of $\mathrm{Cr}$ on the electrochemical corrosion of high Mn steel in a sweet environment. J. Electrochem. Soc. 2016, 163, C791-C797. [CrossRef]

50. Roncery, L.M.; Weber, S.; Theisen, W. Development of Mn-Cr-(C-N) corrosion resistant twinning induced plasticity steels: Thermodynamic and diffusion calculations, production, and characterization. Metall. Mater. Trans. A 2010, 41, 2471-2479. [CrossRef]

51. Jiang, B.; Qi, X.; Yang, S.; Zhou, W.; Hsu, T.Y. Effect of stacking fault probability on $\gamma-\varepsilon$ martensitic transformation and shape memory effect in Fe-Mn-Si based alloys. Acta Mater. 1998, 46, 501-510. [CrossRef]

52. Lee, Y.-K.; Jun, J.-H.; Choi, C.-S. Damping capacity in Fe-Mn binary alloys. ISIJ Int. 1997, 37, 1023-1030. [CrossRef]

53. Bastidas, D.M.; Medina, S.F.; Ress, J.; Jiménez, J.A.; Bastidas, J.M. Revealing austenite stability in Fe-30Mn-5Al-0.5C twinninginduced plasticity steel using differential thermal analysis. Steel Res. Int. 2020, 91, 2000076. [CrossRef]

54. Frommeyer, G.; Brüx, U.; Neumann, P. Supra-ductile and high-strength manganese-TRIP/TWIP steels for high energy absorption purposes. ISIJ Int. 2003, 43, 438-446. [CrossRef]

55. Frommeyer, G.; Grässel, O. Light Constructional Steel and the Use Thereof. Patent PCT/EP98/04044, WO 99/01585 A1, 1998.

56. Dai, Y.; Tang, D.; Mi, Z.; Lü, J. Microstructure characteristics of an Fe-Mn-C TWIP steel after deformation. J. Iron Steel Res. Int. 2010, 17, 53-59. [CrossRef]

57. Karaman, I.; Sehitoglu, H.; Beaudoin, A.; Chumlyakov, Y.; Maier, H.; Tomé, C. Modeling the deformation behavior of Hadfield steel single and polycrystals due to twinning and slip. Acta Mater. 2000, 48, 2031-2047. [CrossRef]

58. ASTM. A128/A128M-19, Standard Specification for Steel Castings, Austenitic Manganese; ASTM International: West Conshohocken, PA, USA, 2019. [CrossRef]

59. Banerji, S.K. An austenitic stainless steel without nickel and chromium. Trans. Indian Inst. Met. 1977, 30, 186-189.

60. World Auto Steel. Future Steel Vehicle Steel Technology Assessment and Design Methodology Interim Report; World Auto Steel: Middletown, $\mathrm{OH}, \mathrm{USA}, 2010$.

61. Zhang, Y.; Zhu, X. Electrochemical polarization and passive film analysis of austenitic Fe-Mn-Al steels in aqueous solutions. Corros. Sci. 1999, 41, 1817-1833. [CrossRef]

62. Cavallini, M.; Felli, F.; Fratesi, R.; Veniaii, F. Aqueous solution corrosion behaviour of "poor man" high manganese-aluminum steels. Mater. Corros. 1982, 33, 281-284. [CrossRef]

63. Pourbaix, M.; Deltombe, E.C.; Vanleugenhagle, M. Atlas of Electrochemical Equilibria in Aqueous Solutions; Elsevier: Oxford, UK, 1966.

64. Delpech, S.; Cannes, C.; Barré, N.; Tran, Q.T.; Sanchez, C.; Lahalle, H.; Lambertin, D.; Gauffinet, S.; Coumes, C.C.D. Kinetic model of aluminum behavior in cement-based matrices analyzed by impedance spectroscopy. J. Electrochem. Soc. 2017, 164, C717-C727. [CrossRef]

65. Tjong, S.C. Aqueous corrosion properties of austenitic Fe-8.7Al-29.7Mn-1.04C alloy. Surf. Coat. Technol. 1986, 28, 181-186. [CrossRef]

66. Altstetter, C.J.; Bentley, A.P.; Fourie, J.W.; Kirkbride, A.N. Processing and properties of Fe-Mn-Al alloys. Mater. Sci. Eng. 1986, 82, 13-25. [CrossRef] 
67. Gau, Y.J.; Wu, J.K. Galvanic corrosion behaviour of Fe-Mn-Al alloys in sea water. J. Mater. Sci. Lett. 1992, 11, 119-121. [CrossRef]

68. Park, I.-J.; Lee, S.-M.; Kang, M.; Lee, S.; Lee, Y.-K. Pitting corrosion behavior in advanced high strength steels. J. Alloys Compd. 2015, 619, 205-210. [CrossRef]

69. Ruščăk, M.; Perng, T.-P. Effect of ferrite on corrosion of Fe-Mn-Al alloys in sodium chloride solution. Corrosion 1995, 51, 738-743. [CrossRef]

70. Shih, S.T.; Tai, C.Y.; Perng, T.P. Corrosion behavior of two-phase Fe-Mn-Al alloys in 3.5\% NaCl solution. Corrosion 1993, 49, 130-134. [CrossRef]

71. Chen, P.-C.; Chao, C.-G.; Liu, T.-F. A novel high-strength, high-ductility and high-corrosion-resistance FeAlMnC low-density alloy. Scr. Mater. 2013, 68, 380-383. [CrossRef]

72. Bastidas, J.M.; Polo, J.L.; Torres, C.L.; Cano, E. A stochastic approach to study localized corrosion of AISI 304L and AISI 316L stainless steels as a function of potential scan rate. Corrosion 2001, 57, 666-669. [CrossRef]

73. Zhu, X.M.; Zhang, Y.S. An XPS study of passive film formation on Fe 30Mn 9Al alloy in sodium sulphate solution. Appl. Surf. Sci. 1998, 125, 11-16. [CrossRef]

74. Hamada, A.S.; Karjalainen, L.P. Corrosion behaviour of high-Mn TWIP steels with electroless Ni-P coating. Open Corros. J. 2010, 3, 1-6. [CrossRef]

75. Yang, M.; Yue, L.; Xie, K.; Zhang, S.; Sun, Y.; Tan, Y. Study on corrosion behavior of TWIP steel and properties of surface electroless Ni-P coatings. Mater. Res. E Express 2020, 7, 036517. [CrossRef]

76. Hamada, A.S.; Karjalainen, L.P.; El-Zeky, M.A. Effect of anodic passivation on the corrosion behaviour of Fe-Mn-Al steels in 3.5\% NaCl. In Passivation of Metals and Semiconductors, and Properties of Thin Oxide Layers; Marcus, P., Maurice, V., Eds.; Elsevier: New York, NY, USA, 2006; pp. 77-82. [CrossRef]

77. Tsai, W.-T.; Duh, J.-B.; Lee, J.-T. Electrochemical polarization and pitting behaviour of Fe-Al-Mn alloys in chloride solutions. J. Mater. Sci. 1987, 22, 3517-3521. [CrossRef]

78. Jabłońska, M.; Michalik, R. Studies on the corrosion properties of high-Mn austenitic steels. Solid State Phenom. 2015, 227, 75-78. [CrossRef]

79. Heger, J.J. Austenitic iron-aluminum-manganese alloys as possible substitutes for austenitic stainless steels. J. Test. Eval. 1985, 13, 446. [CrossRef]

80. Kolman, D.G.; Ford, D.K.; Butt, D.P.; Nelson, T.O. Corrosion of 304 stainless steel exposed to nitric acid-chloride environments. Corros. Sci. 1997, 39, 2067-2093. [CrossRef]

81. Wang, W.; Wang, D.; Han, F. Improvement of corrosion resistance of twinning-induced plasticity steel by hot-dipping aluminum with subsequent thermal diffusion treatment. Mater. Lett. 2019, 248, 60-64. [CrossRef]

82. Hamada, A.S.; Karjalainen, L.P. Nitric acid resistance of new type Fe-Mn-Al stainless steels. Can. Metall. Q. 2006, 45, 41-48. [CrossRef]

83. Fajardo, S.; Llorente, I.; Jiménez, J.A.; Bastidas, J.M.; Bastidas, D.M. Effect of Mn additions on the corrosion behaviour of TWIP Fe-Mn-Al-Si austenitic steel in chloride solution. Corros. Sci. 2019, 154, 246-253. [CrossRef]

84. Tuan, Y.H.; Wang, C.S.; Tsai, C.Y.; Chao, C.G.; Liu, T.F. Corrosion behaviors of austenitic Fe-30Mn-7Al-xCr-1C alloys in 3.5\% $\mathrm{NaCl}$ solution. Mater. Chem. Phys. 2009, 114, 595-598. [CrossRef]

85. Fajardo, S.; Llorente, I.; Jiménez, J.A.; Calderón, N.; Herrán-Medina, D.; Bastidas, J.M.; Ress, J.; Bastidas, D.M. Influence of chromium on the passivity of thermo-mechanically processed high-Mn TWIP steels. Appl. Surf. Sci. 2020, 513, 145852. [CrossRef]

86. Martin, U.; Ress, J.; Bosch, J.; Bastidas, D.M. Effect of thermo-mechanical processing on the corrosion behavior of Fe-30Mn-5Al-0.5C TWIP steel. Appl. Sci. 2020, 10, 9104. [CrossRef]

87. Orazem, M.E.; Miller, M.G. The distribution of current and formation of a salt film on an iron disk below the passivation potential. J. Electrochem. Soc. 1987, 134, 392-399. [CrossRef]

88. Bosch, J.; Martin, U.; Aperador, W.; Bastidas, J.M.; Ress, J.; Bastidas, D.M. Corrosion behavior of high-Mn austenitic Fe-Mn-Al-Cr TWIP steel in $\mathrm{NaCl}$ and $\mathrm{NaOH}$ solutions. Materials 2021, 14, 425. [CrossRef]

89. Mujica, L.; Weber, S.; Theisen, W. Development of high-strength corrosion-resistant austenitic TWIP steel. Metall. Ital. 2011, 6, 31-35.

90. Zhu, X.M.; Zhang, Y.S. Investigation of the electrochemical corrosion behavior and passive film of $\mathrm{Fe}-\mathrm{Mn}, \mathrm{Fe}-\mathrm{Mn}-\mathrm{Al}$, and Fe-Mn-Al-Cr alloys in aqueous solution. Corrosion 1998, 54, 3-12. [CrossRef]

91. Zhang, Y.; Zhu, X.; Liu, M.; Che, R. Effects of anodic passivation on the constitution, stability and resistance to corrosion of passive film formed on an Fe-24Mn-4Al-5Cr alloy. Appl. Surf. Sci. 2004, 222, 89-101. [CrossRef]

92. Schinhammer, M.; Steiger, P.; Moszner, F.; Löffler, J.F.; Uggowitzer, P.J. Degradation performance of biodegradable FeMnC (Pd) alloys. Mater. Sci. Eng. C 2013, 33, 1882-1893. [CrossRef]

93. Zhu, S.M.; Tjong, S.C. Serrated flow in Fe-28Mn-9Al-xC alloys in a temperature range of 573-873 K. Scr. Mater. 1997, 36, 317-321. [CrossRef]

94. Tjong, S.C.; Ku, J.S.; Wu, C.S. Corrosion behavior of laser consolidated chromium and molybdenum plasma spray coatings on Fe-28Mn-7Al-1C alloy. Scr. Metall. Mater. 1994, 31, 835-839. [CrossRef]

95. Tjong, S.C. Performance of laser-consolidated plasma-spray coatings on Fe-28Mn-7A1-1C alloy. Thin Solid Films 1996, 274, 95-100. [CrossRef]

96. Lee, J.-W.; Duh, J.-G.; Tsai, S.-Y. Corrosion resistance and microstructural evaluation of the chromized coating process in a dual phase Fe-Mn-Al-Cr alloy. Surf. Coat. Technol. 2002, 153, 59-66. [CrossRef] 
97. Zhang, Y.; Zhu, X.; Zhong, S. Effect of alloying elements on the electrochemical polarization behavior and passive film of Fe-Mn base alloys in various aqueous solutions. Corros. Sci. 2004, 46, 853-876. [CrossRef]

98. Dieudonné, T.; Marchetti, L.; Wery, M.; Miserque, F.; Tabarant, M.; Chêne, J.; Allely, C.; Cugy, P.; Scott, C.P.P. Role of copper and aluminum on the corrosion behavior of austenitic Fe-Mn-C TWIP steels in aqueous solutions and the related hydrogen absorption. Corros. Sci. 2014, 83, 234-244. [CrossRef]

99. Chen, Y.-C.; Lin, C.-L.; Chao, C.-G.; Liu, T.-F. Excellent enhancement of corrosion properties of Fe-9Al-30Mn-1.8C alloy in 3.5\% $\mathrm{NaCl}$ and $10 \% \mathrm{HCl}$ aqueous solutions using gas nitriding treatment. J. Alloys Compd. 2015, 633, 137-144. [CrossRef]

100. Yuan, X.; Zhao, Y.; Li, X.; Chen, L. Effect of Cr on mechanical properties and corrosion behaviors of Fe-Mn-C-Al-Cr-N TWIP steels. J. Mater. Sci. Technol. 2017, 33, 1555-1560. [CrossRef]

101. Wang, C.S.; Tsai, C.Y.; Chao, C.G.; Liu, T.F. Effect of chromium content on corrosion behaviors of Fe-9Al-30Mn-(3, 5, 6.5, 8) Cr-1C alloys. Mater. Trans. 2007, 48, 2973-2977. [CrossRef]

102. Tsay, G.; Lin, C.; Chao, C.; Liu, T. A new austenitic FeMnAlCrC alloy with high-strength, high-ductility, and moderate corrosion resistance. Mater. Trans. 2010, 51, 2318-2321. [CrossRef]

103. Zhu, X.M.; Zhang, Y.S. Electrochemical polarisation and passive film of austenitic Fe-Mn-Cr-Al alloy in aqueous solution. Br. Corros. J. 1997, 32, 127-132. [CrossRef]

104. Duh, J.-G.; Lee, J.W.; Wang, C.-J. Microstructural development in the oxidation-induced phase transformation of Fe-Al-Cr-Mn-C alloys. J. Mater. Sci. 1988, 23, 2649-2660. [CrossRef]

105. Charles, J.; Berghezan, A.; Lutts, A.; Dancoisne, P.L. New cryogenic material: Fe-Mn-Al alloys. Met. Prog. 1981, 119, 71-74.

106. Chou, J.S.; Chao, C.G. Tensile properties of a $\mathrm{DO}_{3}$ - containing Fe-Mn-Al-Si-C alloy at elevated temperatures. Scr. Metall. Mater. 1992, 26, 1417-1421. [CrossRef]

107. Wang, R.; Beck, F.H. New stainless steel without nickel or chromium for marine applications. Met. Prog. 1983, 123, 72-76.

108. Kannan, M.B.; Raman, R.K.S.; Khoddam, S. Comparative studies on the corrosion properties of a Fe-Mn-Al-Si steel and an interstitial-free steel. Corros. Sci. 2008, 50, 2879-2884. [CrossRef]

109. Lins, V.F.C.; Freitas, M.A.; Silva, E.M.P. Corrosion resistance study of Fe-Mn-Al-C alloys using immersion and potentiostatic tests. Appl. Surf. Sci. 2005, 250, 124-134. [CrossRef]

110. Kwon, H.; Park, K. Effects of manganese on the passivity of Fe-18Cr-xMn (x=0, 6, 12). ECS Trans. 2019, 1, 313-320. [CrossRef]

111. Roberge, P.R. Handbook of Corrosion Engineering; McGraw-Hill: New York, NY, USA, 1999.

112. Abuzriba, M.B.; Musa, S.M. Substitution for Chromium and Nickel in Austenitic Stainless Steels. In 2nd International Multidisciplinary Microscopy and Microanalysis Congress; Polychroniadis, E., Oral, A., Ozer, M., Eds.; Springer: Cham, Switzerland, 2015; Volume 164, pp. 205-214.

113. Moon, K.M.; Kim, D.A.; Kim, Y.H.; Lee, M.H. Effect of Mn content on corrosion characteristics of lean Mn TWIP steel. Int. J. Mod. Phys. B 2018, 32, 1840083. [CrossRef]

114. Dieudonné, T.; Marchetti, L.; Wery, M.; Chêne, J.; Allely, C.; Cugy, P.; Scott, C.P. Role of copper and aluminum additions on the hydrogen embrittlement susceptibility of austenitic Fe-Mn-C TWIP steels. Corros. Sci. 2014, 82, 218-226. [CrossRef]

115. Gavriljuk, V.G.; Shanina, B.D.; Berns, H. Ab initio development of a high-strength corrosion-resistant austenitic steel. Acta Mater. 2008, 56, 5071-5082. [CrossRef]

116. Setiadi, A.; Milestone, N.B.; Hill, J.; Hayes, M. Corrosion of aluminium and magnesium in BFS composite cements. Adv. Appl. Ceram. 2006, 105, 191-196. [CrossRef]

117. Wan, H.; Cai, Y.; Song, D.; Chen, C. Effect of Cr/Mo carbides on corrosion behaviour of Fe-Mn-C twinning induced plasticity steel. Corros. Sci. 2020, 167, 108518. [CrossRef]

118. Gómez, J.A.M.; Antonissen, J.; Palacio, C.A.; de Grave, E. Effects of Si as alloying element on corrosion resistance of weathering steel. Corros. Sci. 2012, 59, 198-203. [CrossRef]

119. Li, D.G.; Wang, J.D.; Chen, D.R.; Liang, P. Molybdenum addition enhancing the corrosion behaviors of $316 \mathrm{~L}$ stainless steel in the simulated cathodic environment of proton exchange membrane fuel cell. Int. J. Hydrogen Energy 2015, 40, 5947-5957. [CrossRef]

120. Kannan, M.B.; Raman, R.K.S.; Khoddam, S.; Liyanaarachchi, S. Corrosion behavior of twinning-induced plasticity (TWIP) steel. Mater. Corros. 2013, 64, 231-235. [CrossRef]

121. Peguet, L.; Malki, B.; Baroux, B. Influence of cold working on the pitting corrosion resistance of stainless steels. Corros. Sci. 2007, 49, 1933-1948. [CrossRef]

122. Fu, Y.; Wu, X.; Han, E.-H.; Ke, W.; Yang, K.; Jiang, Z. Effects of cold work and sensitization treatment on the corrosion resistance of high nitrogen stainless steel in chloride solutions. Electrochim. Acta 2009, 54, 1618-1629. [CrossRef]

123. Mudali, U.K.; Shankar, P.; Ningshen, S.; Dayal, R.K.; Khatak, H.S.; Raj, B. On the pitting corrosion resistance of nitrogen alloyed cold worked austenitic stainless steels. Corros. Sci. 2002, 44, 2183-2198. [CrossRef]

124. Grajcar, A. Corrosion Resistance of High-Mn Austenitic Steels for the Automotive Industry. In Corrosion Resistance; InTech: Rijeka, Croatia, 2012.

125. Wang, K.; Wei, A.; Tong, X.; Lin, J.; Jin, L.; Zhong, X.; Wang, D. Improvement of the anti-corrosion property of twinning-induced plasticity steel by twin-induced grain boundary engineering. Mater. Lett. 2018, 211, 118-121. [CrossRef]

126. Grajcar, A.; Kciuk, M.; Topolska, S.; Płachcińska, A. Microstructure and corrosion behavior of hot-deformed and cold-strained high-Mn steels. J. Mater. Eng. Perform. 2016, 25, 2245-2254. [CrossRef] 
127. Ghayad, I.M.; Hamada, A.S.; Girgis, N.N.; Ghanem, W.A. Effect of cold working on the aging and corrosion behaviour of Fe-Mn-Al stainless steel. Steel GRIPS 2006, 4, 133-137.

128. Bastidas, D.M. Interpretation of impedance data for porous electrodes and diffusion processes. Corrosion 2007, 63, 515-521. [CrossRef]

129. Bastidas, J.; Polo, J.; Torres, C.; Cano, E. A study on the stability of AISI 316L stainless steel pitting corrosion through its transfer function. Corros. Sci. 2001, 43, 269-281. [CrossRef]

130. Karaman, I.; Sehitoglu, H.; Gall, K.; Chumlyakov, Y.; Maier, H. Deformation of single crystal Hadfield steel by twinning and slip. Acta Mater. 2000, 48, 1345-1359. [CrossRef]

131. Speidel, M.O. High Nitrogen Steels. In Proceedings of the International Conference on High Nitrogen Steels HNS 88, Lille, France, 18-20 May 1988; Foct, J., Hendry, A., Eds.; The Institute of Metals: London, UK, 1989; p. 251.

132. Ralston, K.D.; Birbilis, N. Effect of grain size on corrosion: A review. Corrosion 2010, 66, 075005-075013. [CrossRef]

133. Dini, G.; Najafizadeh, A.; Ueji, R.; Monir-Vaghefi, S.M. Tensile deformation behavior of high manganese austenitic steel: The role of grain size. Mater. Des. 2010, 31, 3395-3402. [CrossRef]

134. Yeganeh, M.; Eskandari, M.; Alavi-Zaree, S.R. A comparison between corrosion behaviors of fine-grained and coarse-grained structures of high-Mn steel in $\mathrm{NaCl}$ solution. J. Mater. Eng. Perform. 2017, 26, 2484-2490. [CrossRef]

135. Ueji, R.; Tsuchida, N.; Terada, D.; Tsuji, N.; Tanaka, Y.; Takemura, A.; Kunishige, K. Tensile properties and twinning behavior of high manganese austenitic steel with fine-grained structure. Scr. Mater. 2008, 59, 963-966. [CrossRef]

136. Lu, C.-W.; Lu, Y.-S.; Lai, Z.-H.; Yen, H.-W.; Lee, Y.-L. Comparative corrosion behavior of Fe50Mn30Co10Cr10 dual-phase high-entropy alloy and CoCrFeMnNi high-entropy alloy in $3.5 \mathrm{wt} \% \mathrm{NaCl}$ solution. J. Alloys Compd. 2020, 842, 155824. [CrossRef]

137. So, K.; Kim, J.; Chun, Y.; Park, K.-T.; Lee, Y.-K.; Lee, C.S. Hydrogen delayed fracture properties and internal hydrogen behavior of a Fe-18Mn-1.5Al-0.6C TWIP Steel. ISIJ Int. 2009, 49, 1952-1959. [CrossRef]

138. Park, I.-J.; Lee, S.; Jeon, H.; Lee, Y.-K. The advantage of grain refinement in the hydrogen embrittlement of Fe-18Mn-0.6C twinning-induced plasticity steel. Corros. Sci. 2015, 93, 63-69. [CrossRef]

139. Sun, M.; Xiao, K.; Dong, C.; Li, X.; Zhong, P. Stress corrosion cracking of ultrahigh strength martensite steel Cr9Ni5MoCo14 in $3.5 \% \mathrm{NaCl}$ solution. Aerosp. Sci. Technol. 2014, 36, 125-131. [CrossRef]

140. Eliaz, N.; Shachar, A.; Tal, B.; Eliezer, D. Characteristics of hydrogen embrittlement, stress corrosion cracking and tempered martensite embrittlement in high-strength steels. Eng. Fail. Anal. 2002, 9, 167-184. [CrossRef]

141. Jin, L.Z. The chloride stress-corrosion cracking behavior of stainless steels under different test methods. J. Mater. Eng. Perform. 1994, 3, 734-739. [CrossRef]

142. Tjong, S.C. Stress corrosion cracking of the austenitic Fe-Al-Mn alloy in chloride environment. Mater. Corros. 1986, 37, 444-447. [CrossRef]

143. Huang, Y.-J.; Yamaguchi, T.; Murai, H.; Sugino, H.; Nakajima, T.; Nono, M.; Kawakita, K.; Kimura, A. SCC susceptibility of solution-annealed 316L SS in hydrogenated hot water below $288^{\circ} \mathrm{C}$. Corros. Sci. 2018, 145, 1-9. [CrossRef]

144. Juang, H.K.; Altstetter, C. Effect of $\mathrm{pH}$ and chloride contents on stress corrosion cracking of austenitic stainless steels at room temperature. Corrosion 1990, 46, 881-887. [CrossRef]

145. Prosek, T.; Gac, A.L.; Thierry, D.; Manchet, S.L.; Lojewski, C.; Fanica, A.; Johansson, E.; Canderyd, C.; Dupoiron, F.; Snauwaert, T.; et al. Low-Temperature stress corrosion cracking of austenitic and duplex stainless steels under chloride deposits. Corrosion 2014, 70, 1052-1063. [CrossRef]

146. Chang, S.C.; Liu, J.Y.; Juang, H.K. Environment-assisted cracking of Fe-32\% Mn-9\% $\mathrm{Al}$ alloys in $3.5 \%$ sodium chloride solution. Corrosion 1995, 51, 399-406. [CrossRef]

147. Tjong, S.C.; Wu, C.S. The microstructure and stress corrosion cracking behaviour of precipitation-hardened Fe-8.7Al-29.7Mn-1.04C alloy in 20\% NaCl solution. Mater. Sci. Eng. 1986, 80, 203-211. [CrossRef]

148. Ronevich, J.A.; Kim, S.K.; Speer, J.G.; Matlock, D.K. Hydrogen effects on cathodically charged twinning-induced plasticity steel. Scr. Mater. 2012, 66, 956-959. [CrossRef]

149. Choi, H.; Kim, S.; Sung, H.; Kim, S.-J.; Kim, S. Effect of Cr and N on stress corrosion cracking behavior of Fe-18Mn steel. Korean, J. Met. Mater. 2019, 57, 624-631. [CrossRef]

150. Ryu, J.H.; Kim, S.K.; Lee, C.S.; Suh, D.-W.; Bhadeshia, H.K.D.H. Effect of aluminium on hydrogen-induced fracture behaviour in austenitic Fe-Mn-C steel. Proc. R. Soc. A Math. Phys. Eng. Sci. 2013, 469, 20120458. [CrossRef]

151. Han, D.K.; Kim, Y.M.; Han, H.N.; Bhadeshia, H.K.D.H.; Suh, D.-W. Hydrogen and aluminium in high-manganese twinninginduced plasticity steel. Scr. Mater. 2014, 80, 9-12. [CrossRef]

152. Han, D.K.; Lee, S.K.; Noh, S.J.; Kim, S.-K.; Suh, D.-W. Effect of aluminium on hydrogen permeation of high-manganese twinning-induced plasticity steel. Scr. Mater. 2015, 99, 45-48. [CrossRef]

153. Song, E.J.; Bhadeshia, H.K.D.H.; Suh, D.-W. Interaction of aluminium with hydrogen in twinning-induced plasticity steel. Scr. Mater. 2014, 87, 9-12. [CrossRef]

154. Koyama, M.; Akiyama, E.; Tsuzaki, K. Effects of static and dynamic strain aging on hydrogen embrittlement in TWIP steels containing Al. ISIJ Int. 2013, 53, 1268-1274. [CrossRef]

155. Liu, Q.; Zhou, Q.; Venezuela, J.; Zhang, M.; Wang, J.; Atrens, A. A review of the influence of hydrogen on the mechanical properties of DP, TRIP, and TWIP advanced high-strength steels for auto construction. Corros. Rev. 2016, 34, 127-152. [CrossRef]

156. Timmerscheidt, T.; Dey, P.; Bogdanovski, D.; von Appen, J.; Hickel, T.; Neugebauer, J.; Dronskowski, R. The role of k-carbides as hydrogen traps in high-Mn steels. Metals 2017, 7, 264. [CrossRef] 
157. Park, I.-J.; Jo, S.Y.; Kang, M.; Lee, S.-M.; Lee, Y.-K. The effect of Ti precipitates on hydrogen embrittlement of Fe-18Mn-0.6C-2AlxTi twinning-induced plasticity steel. Corros. Sci. 2014, 89, 38-45. [CrossRef]

158. Haley, D.; Merzlikin, S.V.; Choi, P.; Raabe, D. Atom probe tomography observation of hydrogen in high-Mn steel and silver charged via an electrolytic route. Int. J. Hydrogen Energy 2014, 39, 12221-12229. [CrossRef]

159. Tsu, I.F.; Perng, T.P. Hydrogen compatibility of Femnal alloys. Metall. Trans. A 1991, 22, 215-224. [CrossRef]

160. Lovicu, G.; Bottazzi, M.; D'Aiuto, F.; De Sanctis, M.; Dimatteo, A.; Santus, C.; Valentini, R. Hydrogen embrittlement of automotive advanced high-strength steels. Metall. Mater. Trans. A 2012, 43, 4075-4087. [CrossRef]

161. Michalska, J.; Chmiela, B.; Łabanowski, J.; Simka, W. Hydrogen damage in superaustenitic 904L stainless steels. J. Mater. Eng. Perform. 2014, 23, 2760-2765. [CrossRef]

162. Robinson, M.J.; Kilgallon, P.J. Hydrogen embrittlement of cathodically protected high-strength, low-alloy steels exposed to sulfate reducing bacteria. Corrosion 1994, 50, 626-635. [CrossRef]

163. Louthan, M.; Caskey, G.; Donovan, J.; Rawl, D. Hydrogen embrittlement of metals. Mater. Sci. Eng. 1972, 10, 357-368. [CrossRef]

164. Scott, P.M. A review of environment-sensitive fracture in water reactor materials. Corros. Sci. 1985, 25, 583-606. [CrossRef]

165. Koyama, M.; Akiyama, E.; Sawaguchi, T.; Ogawa, K.; Kireeva, I.V.; Chumlyakov, Y.I.; Tsuzaki, K. Hydrogen-assisted quasicleavage fracture in a single crystalline type 316 austenitic stainless steel. Corros. Sci. 2013, 75, 345-353. [CrossRef]

166. Beachem, C.D. A new model for hydrogen-assisted cracking (hydrogen "embrittlement"). Metall. Mater. Trans. B 1972, 3 , 441-455. [CrossRef]

167. Koyama, M.; Akiyama, E.; Sawaguchi, T.; Raabe, D.; Tsuzaki, K. Hydrogen-induced cracking at grain and twin boundaries in an Fe-Mn-C austenitic steel. Scr. Mater. 2012, 66, 459-462. [CrossRef]

168. Koyama, M.; Akiyama, E.; Tsuzaki, K. Hydrogen embrittlement in a Fe-Mn-C ternary twinning-induced plasticity steel. Corros. Sci. 2012, 54, 1-4. [CrossRef]

169. Koyama, M.; Bashir, A.; Rohwerder, M.; Merzlikin, S.V.; Akiyama, E.; Tsuzaki, K.; Raabe, D. Spatially and kinetically resolved mapping of hydrogen in a twinning-induced plasticity steel by use of scanning Kelvin probe force microscopy. J. Electrochem. Soc. 2015, 162, C638-C647. [CrossRef]

170. Koyama, M.; Akiyama, E.; Tsuzaki, K.; Raabe, D. Hydrogen-assisted failure in a twinning-induced plasticity steel studied under in situ hydrogen charging by electron channeling contrast imaging. Acta Mater. 2013, 61, 4607-4618. [CrossRef]

171. Koyama, M.; Sawaguchi, T.; Tsuzaki, K. Quasi-cleavage fracture along annealing twin boundaries in a Fe-Mn-C austenitic steel. ISIJ Int. 2012, 52, 161-163. [CrossRef]

172. Koyama, M.; Sawaguchi, T.; Tsuzaki, K. Premature fracture mechanism in an Fe-Mn-C austenitic steel. Metall. Mater. Trans. A 2012, 43, 4063-4074. [CrossRef]

173. Koyama, M.; Akiyama, E.; Tsuzaki, K. Effect of hydrogen content on the embrittlement in a Fe-Mn-C twinning-induced plasticity steel. Corros. Sci. 2012, 59, 277-281. [CrossRef]

174. Koyama, M.; Springer, H.; Merzlikin, S.V.; Tsuzaki, K.; Akiyama, E.; Raabe, D. Hydrogen embrittlement associated with strain localization in a precipitation-hardened $\mathrm{Fe}-\mathrm{Mn}-\mathrm{Al}-\mathrm{C}$ light weight austenitic steel. Int. J. Hydrogen Energy 2014, 39, 4634-4646. [CrossRef]

175. Koyama, M.; Akiyama, E.; Lee, Y.-K.; Raabe, D.; Tsuzaki, K. Overview of hydrogen embrittlement in high-Mn steels. Int. J. Hydrogen Energy 2017, 42, 12706-12723. [CrossRef]

176. Chin, K.-G.; Kang, C.-Y.; Shin, S.Y.; Hong, S.; Lee, S.; Kim, H.S.; Kim, K.; Kim, N.J. Effects of Al addition on deformation and fracture mechanisms in two high manganese TWIP steels. Mater. Sci. Eng. A 2011, 528, 2922-2928. [CrossRef]

177. Chun, Y.S.; Park, K.-T.T.; Lee, C.S. Delayed static failure of twinning-induced plasticity steels. Scr. Mater. 2012, 66, 960-965. [CrossRef]

178. Park, I.-J.; Jeong, K.-H.; Jung, J.-G.; Lee, C.S.; Lee, Y.-K. The mechanism of enhanced resistance to the hydrogen delayed fracture in Al-added Fe-18Mn-0.6C twinning-induced plasticity steels. Int. J. Hydrogen Energy 2012, 37, 9925-9932. [CrossRef]

179. Song, S.W.; Kwon, Y.J.; Lee, T.; Lee, C.S. Effect of Al addition on low-cycle fatigue properties of hydrogen-charged high-Mn TWIP steels. Mater. Sci. Eng. A 2016, 677, 421-430. [CrossRef]

180. Noh, H.-S.; Kang, J.-H.; Kim, S.-J. Effect of grain size on hydrogen embrittlement in stable austenitic high-Mn TWIP and high-N stainless steels. Int. J. Hydrogen Energy 2019, 44, 25076-25090. [CrossRef]

181. Jung, J.-K.; Lee, O.-Y.; Park, Y.-K.; Kim, D.-E.; Jin, K.-G. Hydrogen embrittlement behavior of high Mn TRIP/TWIP steels. Korean J. Mater. Res. 2008, 18, 394-399. [CrossRef]

182. Ronevich, J.A.; de Cooman, B.C.; Speer, J.G.; de Moor, E.; Matlock, D.K. Hydrogen effects in prestrained transformation induced plasticity steel. Metall. Mater. Trans. A 2012, 43, 2293-2301. [CrossRef]

183. Suh, D.-W. Critical assessment 2: Hydrogen induced fracture in austenitic, high-manganese TWIP steel. Mater. Sci. Technol. 2014, 30, 1131-1134. [CrossRef]

184. Grajcar, A.; Krukiewiez, W.; Kołodziej, S. Corrosion behavior of plastically deformed high-Mn austenitic steels. J. Achiev. Mater. Manuf. Eng. 2010, 43, 228-235.

185. Grajcar, A.; Kolodziej, S.; Krukiewiez, W. Corrosion resistance of high-manganese austenitic steels. Arch. Mater. Sci. Eng. 2010, $41,77-84$.

186. Colla, V.; de Sanctis, M.; Dimatteo, A.; Lovicu, G.; Valentini, R. Prediction of continuous cooling transformation diagrams for dual-phase steels from the intercritical region. Metall. Mater. Trans. A 2011, 42, 2781-2793. [CrossRef] 
187. Fu, H.; Wang, W.; Zhao, H.; Jin, F.; Li, J. Study of hydrogen-induced delayed fracture in high-Mn TWIP/TRIP steels during in situ electrochemical hydrogen-charging: Role of microstructure and strain rate in crack initiation and propagation. Corros. Sci. 2020, 162, 108191. [CrossRef]

188. Sheng, Z.; Altenbach, C.; Prahl, U.; Zander, D.; Bleck, W. Effect of cutting method on hydrogen embrittlement of high-Mn TWIP steel. Mater. Sci. Eng. A 2019, 744, 10-20. [CrossRef]

189. Wang, D.; Lu, X.; Deng, Y.; Guo, X.; Barnoush, A. Effect of hydrogen on nanomechanical properties in Fe-22Mn-0.6C TWIP steel revealed by in-situ electrochemical nanoindentation. Acta Mater. 2019, 166, 618-629. [CrossRef]

190. Otto, M.; John, D.; Schmidt-Juergensen, R.; Springub, B.; Cornelissen, M.; Berkhout, B.; Bracke, L.; Patel, J. HSD-Steels Optimized High Strength and High Ductility Austenitic Steel. In Proceedings of the 2nd International Conference Super-High Strength Steels, Peschiera del Garda, Italy, 17-20 October 2010.

191. Shin, S.H.; Hong, S.; Kim, H.S.; Lee, S.; Kim, N.J. Tensile Properties and Cup Formability of High Mn and Al-Added TWIP Steels. In Proceedings of the 2nd International Conference Super-High Strength Steels, Peschiera del Garda, Italy, 17-20 October 2010; pp. 1-9.

192. Xu, C.; Zhang, Y.; Liu, W.; Jin, Y.; Wen, L.; Sun, D. Influence of laser-welding on microstructure and corrosion properties of twinning-induced plasticity (TWIP) steel. Materials 2020, 13, 4315. [CrossRef]

193. Monrrabal, G.; Jiménez, J.A.; Ress, J.; Fajardo, S.; Bastidas, J.M.; Llorente, I.; Bastidas, D.M. Corrosion behaviour of resistancespot-welded high-Mn austenitic TWIP steel. Corros. Eng. Sci. Technol. 2020, 55, 1-10. [CrossRef]

194. Herms, E.; Olive, J.; Puiggali, M. Hydrogen embrittlement of 316L type stainless steel. Mater. Sci. Eng. A 1999, 272, 279-283. [CrossRef]

195. West, A.J.; Louthan, M.R. Dislocation transport and hydrogen embrittlement. Metall. Trans. A 1979, 10, 1675-1682. [CrossRef]

196. Whiteman, M.B.; Troiano, A.R. Hydrogen embrittlement of austenitic stainless steels. Corrosion 1965, 21, 53-56. [CrossRef]

197. Michler, T.; Marchi, C.S.; Naumann, J.; Weber, S.; Martin, M. Hydrogen environment embrittlement of stable austenitic steels. Int. J. Hydrogen Energy 2012, 37, 16231-16246. [CrossRef]

198. Müllner, P. On the ductile to brittle transition in austenitic steel. Mater. Sci. Eng. A 1997, 234-236, 94-97. [CrossRef]

199. Karaman, I.; Sehitoglu, H.; Maier, H.; Chumlyakov, Y. Competing mechanisms and modeling of deformation in austenitic stainless steel single crystals with and without nitrogen. Acta Mater. 2001, 49, 3919-3933. [CrossRef]

200. Pérez, P.; Pérez, F.J.; Gómez, C.; Adeva, P. Oxidation behaviour of an austenitic Fe-30Mn-5Al-0.5C alloy. Corros. Sci. 2002, 44, 113-127. [CrossRef]

201. Park, S.H.; Chung, I.S.; Kim, T.W. Characterization of the high-temperature oxidation behaviour of Fe-25Mm-5Al-0.5C alloy. Oxid. Met. 1998, 49, 349-371. [CrossRef]

202. Tomaszewicz, P.; Wallwork, G.R. The oxidation of Fe-Al alloys containing chromium, nickel or manganese. Corrosion 1984, 40, 152-157. [CrossRef]

203. Erhart, H.; Wang, R.; Rapp, R.A. In situ SEM study of the high-temperature oxidation of an Fe-Mn-Al-Si alloy. Oxid. Met. 1984, 21, 81-88. [CrossRef]

204. Kao, C.H.; Wan, C.M. Effect of carbon on the oxidation of Fe-5.5Al-0.55 C alloy. J. Mater. Sci. 1987, 22, 3203-3208. [CrossRef]

205. Kao, C.H.; Wan, C.M. Effect of temperature on the oxidation of Fe-7.5Al-0.65C alloy. J. Mater. Sci. 1988, 23, 1943-1947. [CrossRef]

206. Pérez, P.; Garcés, G.; Pérez, F.J.; Gómez, C.; Adeva, P. Influence of chromium additions on the oxidation resistance of an austenitic Fe-30Mn-5Al alloy. Oxid. Met. 2002, 57, 339-361. [CrossRef]

207. Lins, V.D.F.C.; Freitas, M.A.; Silva, E.S.D.P. Oxidation kinetics of an Fe-31.8Mn-6.09Al-1.60Si-0.40C alloy at temperatures from 600 to $900{ }^{\circ}$ C. Corros. Sci. 2004, 46, 1895-1907. [CrossRef]

208. Razmpoosh, M.H.; Biro, E.; Chen, D.L.; Goodwin, F.; Zhou, Y. Liquid metal embrittlement in laser lap joining of TWIP and medium-manganese TRIP steel: The role of stress and grain boundaries. Mater. Charact. 2018, 145, 627-633. [CrossRef]

209. Saha, D.C.; Han, S.; Chin, K.G.; Choi, I.; Park, Y.-D. Weldability evaluation and microstructure analysis of resistance-spot-welded high-Mn steel in automotive applications. Steel Res. Int. 2012, 83, 352-357. [CrossRef]

210. Zeytin, H.K.; Emre, H.E.; Kaçar, R. Properties of resistance spot-welded TWIP steels. Metals 2017, 7, 14. [CrossRef]

211. Rossini, M.; Spena, P.R.; Cortese, L.; Matteis, P.; Firrao, D. Investigation on dissimilar laser welding of advanced high strength steel sheets for the automotive industry. Mater. Sci. Eng. A 2015, 628, 288-296. [CrossRef]

212. Razmpoosh, M.H.; Shamanian, M.; Esmailzadeh, M. The microstructural evolution and mechanical properties of resistance spot welded Fe-31Mn-3Al-3Si TWIP steel. Mater. Des. 2015, 67, 571-576. [CrossRef]

213. Roncery, L.M.; Weber, S.; Theisen, W. Welding of twinning-induced plasticity steels. Scr. Mater. 2012, 66, 997-1001. [CrossRef]

214. Zambrano, O.A.; Aguilar, Y.; Valdés, J.; Rodríguez, S.A.; Coronado, J.J. Effect of normal load on abrasive wear resistance and wear micromechanisms in FeMnAlC alloy and other austenitic steels. Wear 2016, 348-349, 61-68. [CrossRef]

215. Astudillo, A.P.C.; Soriano, G.A.F.; Osorio, G.M.B.; Sthepa, H.S.; Ramos, J.; Durán, J.F.; Alcázar, G.A.P. Comparative study of the mechanical and tribological properties of a Hadfield and a Fermanal steel. Hyperfine Interact. 2017, 238, 56. [CrossRef]

216. Zambrano, O.A.; Valdés, J.; Rodriguez, L.A.; Reyes, D.; Snoeck, E.; Rodríguez, S.A.; Coronado, J.J. Elucidating the role of K-carbides in Fe Mn Al C alloys on abrasion wear. Tribol. Int. 2019, 135, 421-431. [CrossRef]

217. Mujica, L.; Jácome, L.A.; Aghajani, A.; Theisen, W.; Weber, S. Subsurface characterization of high-strength high-interstitial austenitic steels after impact wear. Wear 2018, 402-403, 137-147. [CrossRef]

218. Hamada, A.S.; Sahu, P.; Porter, D.A. Indentation property and corrosion resistance of electroless nickel-phosphorus coatings deposited on austenitic high-Mn TWIP steel. Appl. Surf. Sci. 2015, 356, 1-8. [CrossRef] 
219. Chen, L.; Zhao, Y.; Qin, X. Some aspects of high manganese twinning-induced plasticity (TWIP) steel, a review. Acta Metall. Sin. 2013, 26, 1-15. [CrossRef]

220. Allam, T.; Guo, X.; Sevsek, S.; Lipińska-Chwałek, M.; Hamada, A.S.; Ahmed, E.; Bleck, W. Development of a Cr-Ni-V-N medium manganese steel with balanced mechanical and corrosion properties. Metals 2019, 9, 705. [CrossRef]

221. Hermawan, H.; Mantovani, D. Process of prototyping coronary stents from biodegradable Fe-Mn alloys. Acta Biomater. 2013, 9 , 8585-8592. [CrossRef] [PubMed]

222. Bajaj, P.; Hariharan, A.; Kini, A.; Kürnsteiner, P.; Raabe, D.; Jägle, E.A. Steels in additive manufacturing: A review of their microstructure and properties. Mater. Sci. Eng. A 2020, 772, 138633. [CrossRef]

223. Chou, D.-T.; Wells, D.; Hong, D.; Lee, B.; Kuhn, H.; Kumta, P.N. Novel processing of iron-manganese alloy-based biomaterials by inkjet 3-D printing. Acta Biomater. 2013, 9, 8593-8603. [CrossRef] [PubMed]

224. Niendorf, T.; Brenne, F.; Hoyer, P.; Schwarze, D.; Schaper, M.; Grothe, R.; Wiesener, M.; Grundmeier, G.; Maier, H.J. Processing of new materials by additive manufacturing: Iron-based alloys containing silver for biomedical applications. Metall. Mater. Trans. A 2015, 46, 2829-2833. [CrossRef]

225. Shuai, C.; Yang, W.; Yang, Y.; Pan, H.; He, C.; Qi, F.; Xie, D.; Liang, H. Selective laser melted Fe-Mn bone scaffold: Microstructure, corrosion behavior and cell response. Mater. Res. Express 2020, 7, 015404. [CrossRef]

226. Hermawan, H.; Dubé, D.; Mantovani, D. Degradable metallic biomaterials: Design and development of Fe-Mn alloys for stents. J. Biomed. Mater. Res. Part. A 2009, 93, 1-11. [CrossRef]

227. Heiden, M.; Kustas, A.; Chaput, K.; Nauman, E.; Johnson, D.; Stanciu, L. Effect of microstructure and strain on the degradation behavior of novel bioresorbable iron-manganese alloy implants. J. Biomed. Mater. Res. Part. A 2015, 103, 738-745. [CrossRef] [PubMed] 